Universidade de São Paulo

Faculdade de Filosofia, Letras e Ciências Humanas

Departamento de Ciência Política

\title{
Um passo adiante, dois passos para trás: o PMDB de 1979 a 1982
}

Rafael Moreira Dardaque Mucinhato

\author{
Vol. 1 \\ (Versão corrigida) \\ São Paulo
}


Universidade de São Paulo

Faculdade de Filosofia, Letras e Ciências Humanas

Departamento de Ciência Política

\section{Um passo adiante, dois passos para trás: o PMDB de 1979 a 1982}

Rafael Moreira Dardaque Mucinhato

Dissertação apresentada ao

Departamento de Ciência Política da

Faculdade de Filosofia, Letras e

Ciências Humanas, para a obtenção

do título de mestre em Ciência

Política.

Orientador: Prof. Dr. André Vitor Singer

Vol. 1

(Versão corrigida)

São Paulo 


\section{Agradecimentos}

Agradeço a toda minha família pelo apoio que sempre me foi dado na escolha de minha profissão. Agradeço especialmente aos meus avós, Norma Moreira Dardaqui, que me presenteia com livros desde a minha infância, e Eduardo Dardaqui, que me levava à escola todos os dias desde o início da minha vida escolar.

Agradeço a todos os amigos com quem tenho convivido desde que passei a morar em São Paulo, sobretudo àqueles que dividiram um teto comigo. Agradeço especialmente a Tâmara Kovacs, pela minuciosa revisão da versão final deste trabalho.

Agradeço aos funcionários do Departamento de Ciência Política por toda a ajuda que me foi dada para "enfrentar" a burocracia de uma pósgraduação na USP.

Devo também boa parte do meu enriquecimento intelectual e cultural aos colegas de graduação e aos colegas de profissão do Departamento de Ciência Política, que estiveram ao meu lado em toda minha trajetória no prédio das Ciências Sociais da Faculdade de Filosofia, Letras e Ciências Humanas.

Agradeço também a Ana Maria Pereira Machado pelo apoio que me foi dado no momento em que decidi me dedicar aos estudos e seguir na Pós Graduação.

Não poderia também deixar de citar aqui a Capes, pelo apoio financeiro para o desenvolvimento desta pesquisa, e o meu orientador Prof. Dr. André Singer, com quem pude manter um diálogo intenso sobre esta pesquisa e sobre muitos outros temas da política brasileira desde que nos conhecemos. O convívio nestes últimos anos tem sido extremamente estimulante intelectualmente e assim seguirá sendo no futuro. 


\section{Resumo}

Esta pesquisa se propõe a ser um estudo de caso acerca do Partido do Movimento Democrático Brasileiro, o PMDB. Analiso, de maneira interpretativa, os primeiros anos do partido após a restauração do pluripartidarismo, com um recorte histórico de 1979 - momento da sua (re)fundação em meio ao processo de abertura política - até as eleições de 1982 - momento no qual o partido disputa um pleito pela primeira vez. A análise ressalta a movimentação de grupos internos ao partido, notadamente a existência inicial de uma ala de esquerda herdada do Movimento Democrático Brasileiro - MDB (fenômeno não apontado pela literatura sobre o Partido) e o aumento da heterogeneidade interna do PMDB com o correr dos primeiros anos, como consequência da incorporação do Partido Popular, aspectos esses que são também negligenciados pela literatura.

Palavras-chave: partidos políticos, PMDB, PP, democratização, Regime Militar 


\begin{abstract}
This study aims to be a study case regarding a specific political party, the "Partido do Movimento Democrático Brasileiro", PMDB. I analyze interpretatively its first years after multipartyism restarted in Brazil, in a historical period beginning in 1979, when the party is "(re)founded" during the democratization, until 1982 elections, when the party faces an election for the first time. The analysis highlights the movement of internal groups within the party, especially the initial existence of a left wing inherited by the "Movimento Democrático Brasileiro" - MDB (a phenomenon yet mentioned by the literature about the Party) and the increase of PMDB's internal heterogeneity in the course of its first years, as a result of the merger of the "Partido Popular", aspects which are also neglected by the literature.
\end{abstract}

Key-words: political parties, PMDB, PP, democratization, Military Regime 


\section{Lista de tabelas}

Tabela 1. Distribuição de Ministérios e Secretarias Especiais ocupadas pelo PMDB ao longo dos governos pós-redemocratização (1985-2010) ................................................................ 16

Tabela 2. Número de governadores eleitos pelo PMDB (1982-2010).................................17

Tabela 3. Bancadas do PMDB na posse após cada eleição (1982-2010) ................................. 18

Tabela 4. Número de prefeitos eleitos pelo PMDB e porcentagem de cargos conquistados

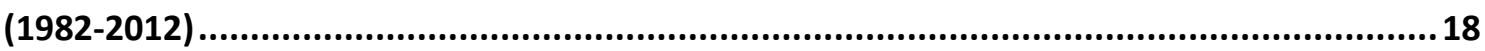

Tabela 5. Composição da Câmara dos Deputados após a Reforma Partidária de 1979..........42

Tabela 6. Composição do Senado Federal após a Reforma Partidária de 1979 ....................... 42

Tabela 7. Diretórios Municipais eleitos em 12/10/1980 ...................................................62

Tabela 8. Comparação entre a filiação partidária prévia dos componentes do Diretório Nacional do PMDB eleitos na primeira Convenção Nacional e após a Convenção que aceitou

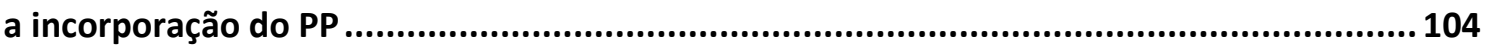

Tabela 9. Distribuição partidária no Congresso antes e após a Incorporação do PP ao PMDB 105

Tabela 10. Quantidade de candidatos por partido em 1982 ........................................... 119

Tabela 11. Número de prefeitos eleitos por partido em 1982 ............................................. 120

Tabela 12. Porcentagem de vereadores eleitos por partido em 1982 ................................120

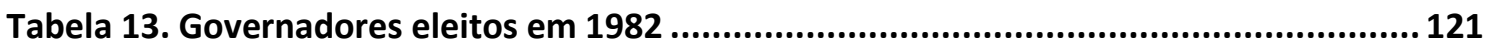

Tabela 14. Cadeiras obtidas, percentual de votos e votação total por partido nas eleições para as Assembleias Legislativas em 1982 ........................................................................ 123

Tabela 15. Cadeiras e percentual de votos obtidos por partido e por Estado nas eleições para

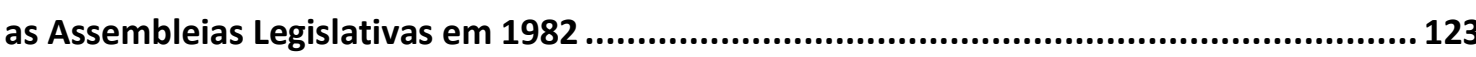

Tabela 16. Distribuição regional dos Deputados Estaduais eleitos pelos partidos em 1982.124

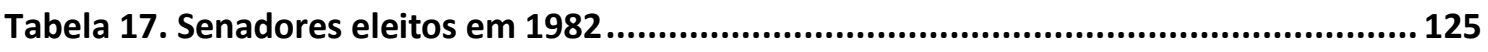

Tabela 18. Tamanho das bancadas no Senado Federal após as eleições de 1982 ................. 126

Tabela 19. Cadeiras obtidas e percentual de votos total por partido e por Estado nas eleições para a Câmara dos Deputados em 1982 ...................................................................... 127

Tabela 20. Distribuição regional dos Deputados Federais eleitos pelos partidos em 1982 .. 128

Tabela 21. Filiação partidária pregressa dos ex-pepistas que compõem a bancada do PMDB no Senado Federal após as eleições de 1982

Tabela 22. Evolução do número de ex-filiados à Arena e ao MDB na bancada do PMDB do

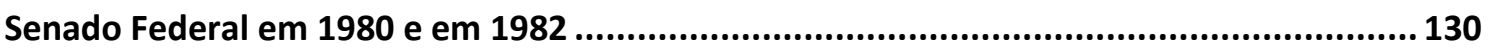

Tabela 23. Filiação partidária pregressa dos ex-pepistas eleitos para a Câmara dos Deputados pelo PMDB em 1982 131 
Tabela 24. Evolução do número de ex-filiados à Arena e ao MDB na bancada do PMDB na Câmara dos Deputados em 1980 e em 1982 132 


\section{Índice}

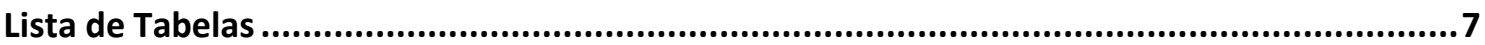

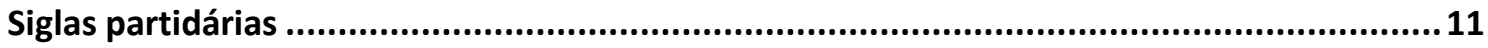

Introdução

Aspectos metodológicos............................................................................................. 24

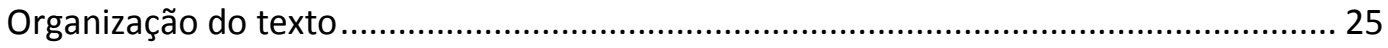

Capítulo 1 - 0 enfoque monográfico e os partidos políticos brasileiros .................................28

1. Os estudos monográficos na Ciência Política brasileira ................................................... 29

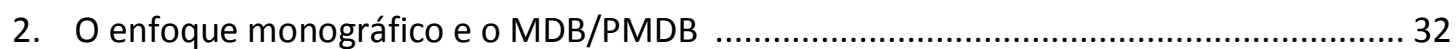

Capítulo 2 - 0 processo de refundação do MDB: surge o PMDB (1979-1980) ........................ 39

1. Conjuntura histórica e o novo cenário partidário .......................................................... 40

2. As subunidades internas e a perda de quadros do MDB para os outros partidos ............44

3. As exigências da nova Lei dos Partidos e o caráter parlamentar do herdeiro do MDB ... 49

4. Os primeiros documentos do partido: nasce o herdeiro do MDB................................... 52

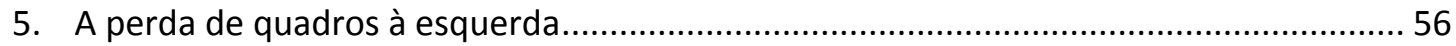

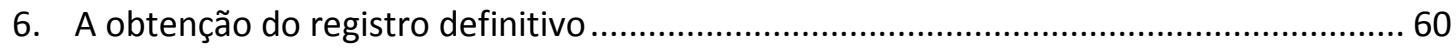

7. A reabertura da Câmara e o princípio da atuação parlamentar da bancada peemedebista

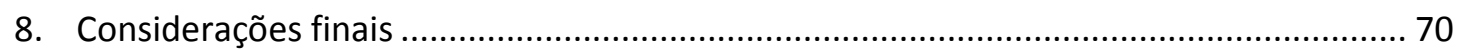

Capítulo 3 - Aproximação e incorporação do Partido Popular (1981-1982) ........................... 73

1. A fundação do PP: composição interna, posicionamento ideológico e organização

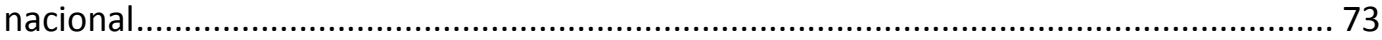

2. O processo de aproximação entre os partidos .................................................................. 83

3. Um novo "Pacote Eleitoral" põe fim ao PP..................................................................... 90

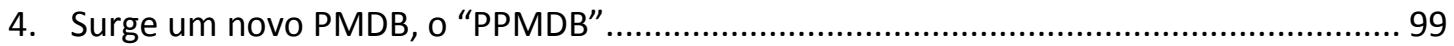

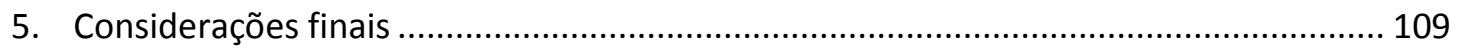

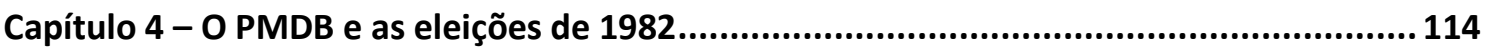

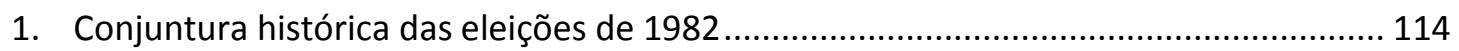

2. O desempenho do PMDB em seu primeiro teste eleitoral............................................ 118

3. O resultado das eleições e o aumento da heterogeneidade interna do PMDB ............. 129

Capítulo 5 - Consideraç̧̃̃es finais ...................................................................................... 134

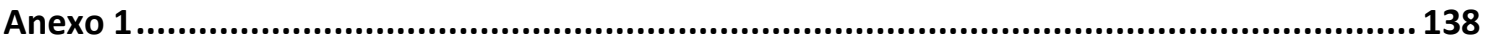

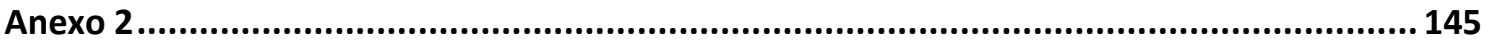


Anexo 3.

Anexo 4 ............................................................................................... 148

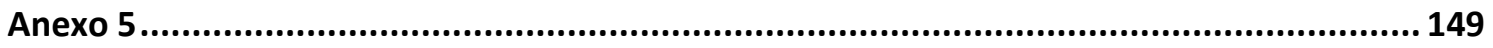

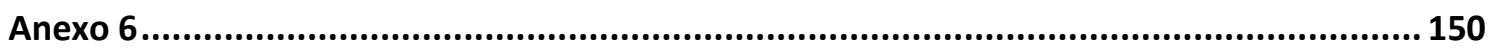

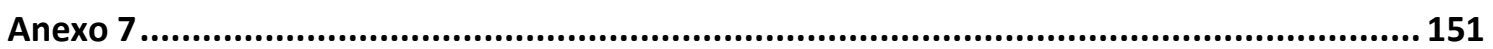

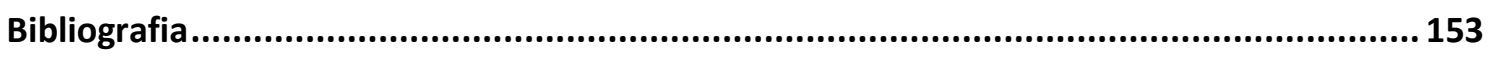




\section{Siglas partidárias}

\section{República de 1945-1964}

PSD - Partido Social Democrático

PTB - Partido Trabalhista Brasileiro

PSP - Partido Social Progressista

UDN - União Democrática Nacional

PDC - Partido Democrata Cristão

PST - Partido Social Trabalhista

\section{Regime autoritário 1965-1979}

MDB - Movimento Democrático Brasileiro

ARENA - Aliança Renovadora Nacional

\section{Pluripartidarismo pós-1979}

PCB - Partido Comunista Brasileiro

PCdoB - Partido Comunista do Brasil

PMDB - Partido do Movimento Democrático Brasileiro

PP - Partido Popular

PDS - Partido Democrático Social

PT - Partido dos Trabalhadores

PFL - Partido da Frente Liberal

DEM - Democratas

PSDB - Partido da Social Democracia Brasileira

PDT - Partido Democrático Trabalhista

PPB - Partido Progressista Brasileiro 
"Não seria exagero afirmar que a deformação mórbida (do PMDB) começou já em 1981, com a incorporação do PP (ironicamente apelidado 'partido dos patrões', ou 'partido clandestino da burguesia') ao PMDB."

(Benevides, 1986)

“(...) o PP resultou inviável, fundiu-se ao PMDB e trouxe no seu bojo (como uma espécie de "presente de grego", de cavalo de Tróia) uma descaracterização deste como um partido exclusivamente composto por pessoas que combateram a ditadura. Muitos dos que vieram do PP junto com o Tancredo eram altamente comprometidos com os acontecimentos

do período autoritário." (Entrevista de Renato Archer, fundador do PMDB e Ministro da Ciência e da Tecnologia e da Previdência durante o governo Sarney; em Melhem e Russo, 2004, p. 404). 


\section{Introdução}

A existência de um sistema partidário e dos partidos que o compõe são elementos fundamentais para a manutenção de um regime democrático representativo. Em função disso, os partidos políticos brasileiros há muito têm sido objeto de estudo sistemático por parte da Ciência Política, em geral sob três enfoques principais.

No primeiro deles, parte da literatura analisou o desempenho dos partidos no cumprimento de sua função mediadora entre eleitores e sistema político (Braga \& Pimentel Jr, 2011; Braga \& Kinzo, 2007; Carreirão \& Kinzo, 2004; Veiga, 2007; entre outros). Em outro, autores destacaram o importante papel dos partidos na estruturação do jogo político na arena governamental, tanto no Poder Legislativo quanto no Poder Executivo (Figueiredo \& Limongi, 1999, 2007; Melo \& Câmara 2012; Power \& Zucco, 2011; Amorim Neto 2000, 2007; entre outros). Por fim, há os chamados "estudos monográficos", cujo enfoque se detém em um partido político por meio de abordagem nacional ou regional (Benevides, 1981; Kinzo, 1988; D’Araújo, 1996; Hippolito, 2012; Ribeiro, 2010 , entre outros).

O enfoque monográfico surgiu na literatura brasileira no início dos anos 1980 e desde então tem contribuído para a compreensão dos partidos que compuseram o sistema político brasileiro em diferentes momentos históricos. O estudo de Hippolito (2012) a respeito do PSD (1945-1964), por exemplo, explicitou a fragmentação que existia naquele partido e como este aspecto interno contribuiu para o processo de radicalização que culminaria no Golpe de 1964. A obra de Kinzo (1988) sobre o MDB (19661979) mostrou como se desenvolveu a oposição feita por uma organização político-partidária no interior do arcabouço institucional montado pelo Regime Militar. Por sua vez, a obra de 
Keck (1991) sobre a formação do PT (1979-1983) demonstrou como o processo de fundação daquela sigla representou experiência inédita na vida partidária brasileira. É por reconhecer os méritos desta abordagem que o presente estudo pretende se inserir nesta tradição.

Os primeiros anos do pluripartidarismo restabelecido em 1980 compreendem um recorte de tempo com eventos significativos para analisar o desenvolvimento dos partidos num país em pleno processo de redemocratização. Foi um período no qual se combinaram a extinção forçada do bipartidarismo e a formação de novos partidos, ainda em um contexto de regime autoritário.

O objetivo desta pesquisa é realizar um estudo de caso sobre o Partido do Movimento Democrático Brasileiro (PMDB) na conjuntura de 1979 a 1982, analisando a fundação do partido e as consequências para o mesmo da incorporação do Partido Popular (PP), ocorrida após a Promulgação do Pacote de Novembro de 1981 pelo Regime Militar. A relevância deste estudo, está em que o PMDB foi ator importante do processo de transição do regime autoritário para a democracia. Além disso, sua forte presença na política nacional e o seu desempenho eleitoral desde sua (re)fundação em 1980 até hoje demonstram que essa relevância permanece atual. A pouca quantidade de estudos de Ciência Política sobre o PMDB justificam, também, o interesse de estudá10 .

Nascido do Movimento Democrático Brasileiro (MDB), o PMDB é o partido mais longevo do atual período pluripartidário ${ }^{1}$. Herdeiro de grande parte da oposição institucional à ditadura, o partido foi

\footnotetext{
${ }^{1}$ A concessão do Registro Definitivo do Partido, da qual originou o processo de registro $\mathrm{n}^{\circ} 38$, foi deferida em sessão do dia 30 de junho de 1981, publicada no Diário da Justiça de 8 de agosto de 1981. Pedido de Registro Definitivo - RGP no 38 - Resolução/TSE n ${ }^{\circ}$ 11.042. Num país como o Brasil, cujos partidos políticos têm apresentado, como um de seus traços principais, baixa longevidade e descontinuidade, o PMDB pode ser visto como notável exceção (Ferreira, 2001).
} 
um dos principais atores na organização da campanha pelo restabelecimento das eleições diretas para presidente da República no final do Regime Militar, por meio do movimento das "DiretasJá" em 1983-1984², o qual, apesar de toda a pressão popular, não obteve sucesso na aprovação da Emenda Dante de Oliveira ${ }^{3}$. Um ano após essa derrota, em aliança com um grupo de dissidentes do partido governista (que posteriormente originaria o Partido da Frente Liberal, o PFL), o PMDB logrou eleger, por meio da "Aliança Democrática" e do voto indireto, o primeiro presidente civil depois de mais de 20 anos de regime autoritário, com a escolha de Tancredo Neves pelo Colégio Eleitoral em janeiro de $1985^{4}$. Após o inesperado falecimento do Presidente eleito, o partido chega ao Poder Executivo nacional através da posse do candidato à vice, José Sarney, filiado ao partido por motivos legais, que exerceu o mandato presidencial de 1985 a 1990 . Durante esse mandato foram eleitos os parlamentares que fariam parte da Assembleia Nacional Constituinte (ANC) de 1987-1988, que viria a promulgar a Constituição de 1988. Na ANC o PMDB foi o partido que deteve a maior bancada: dos 594 parlamentares, 322 $(54,3 \%)$ eram filiados ao PMDB no início dos seus trabalhos 5 .

Para além do cargo de presidente da República exercido por José Sarney (1985-1990), outros três presidentes da República tiveram histórico de militância política ligada ao partido: Fernando Collor de Mello, Itamar Franco e Fernando Henrique Cardoso. Apesar do fato de o PMDB não apresentar candidato próprio nas eleições presidenciais de 1998 a $2014^{6}$, o Partido nunca deixou de ocupar postos importantes no Poder Executivo Nacional. Entre

\footnotetext{
${ }^{2}$ Sobre o papel do PMDB nas "Diretas-Já" ver Leonelli e Oliveira (2004) e Kotscho (1984).

${ }^{3}$ Emenda esta apresentada por um Deputado da bancada do PMDB na Câmara dos Deputados.

${ }^{4}$ Sobre a eleição de Tancredo Neves pelo Colégio Eleitoral de 1985 ver Skidmore (2004) entre outros.

${ }^{5} \mathrm{http} / / / \mathrm{www} 2 . c a m a r a . l e g . b r / a t i v i d a d e-l e g i s l a t i v a /$ legislacao/Constituicoes_Brasileiras/constituicaocidada/constituintes, consultado em 20/11/2014.

${ }^{6}$ Após o restabelecimento das eleições diretas para o cargo de Presidente da República, o partido obteve dois desempenhos eleitorais muito ruins nas eleições presidenciais de 1989 e 1994, ficando abaixo dos 5\% dos votos nacionais (Braga, 2010, p.63), deixando de apresentar candidatos próprios a partir de então. Sobre a evolução do papel do PMDB frente à bipolarização da competição partidária brasileira, ver Simoni e Borges (2011).
} 
Ministérios e Secretarias Especiais com status de Ministérios, o partido ocupou 72 pastas ministeriais ou secretarias especiais de 1985 a 2010 , como se pode ver na tabela abaixo.

Tabela 1. Distribuição de Ministérios e Secretarias Especiais com status ministerial ocupados pelo PMDB ao longo dos governos pós-redemocratização (1985-2010)

\begin{tabular}{lcc}
\hline Governo & $\begin{array}{c}\text { Número de Ministros/ } \\
\text { Secretários Especiais }\end{array}$ & $\begin{array}{c}\text { \% de Secretários } \\
\text { Especiais/ } \\
\text { Ministros do partido }\end{array}$ \\
\hline Sarney & 36 & $52 \%$ \\
\hline Collor & $1^{*}$ & $3,1 \%$ \\
\hline Itamar & 8 & $14,2 \%$ \\
\hline FHC 1 & 7 & $15,9 \%$ \\
\hline FHC 2 & 6 & $10,5 \%$ \\
\hline Lula 1 & 5 & $7,8 \%$ \\
\hline Lula 2 & 9 & $12,5 \%$ \\
\hline \hline
\end{tabular}

Fontes: Oliveira (2012), Meneguello (1996) e Banco de dados do NECON (Núcleo de Estudos do Congresso) - UERJ

* Durante o breve governo Collor, o PMDB ocupou apenas um gabinete ministerial, o Ministério da Justiça, e por um curto intervalo de tempo, de março a outubro de 1990, com José Bernardo Cabral.

O partido também se caracteriza por ser regionalmente forte. Foram 71 governadores eleitos pela legenda de 1982 a 2012 (vide Tabela 2). O grande boom eleitoral do PMDB nas disputas pelos governos estaduais foi em 1986. A partir de então o número de governadores eleitos pela legenda começou a declinar (Ferreira, 2001), mantendo essa trajetória até 2002 e posteriormente se estabilizando.

Quanto à esfera legislativa, o partido é uma das maiores forças do país desde as primeiras eleições sob o pluripartidarismo, tornando-se um interlocutor indispensável para a manutenção da governabilidade de qualquer que seja a coalizão do governo em exercício no Poder Executivo Nacional. Durante o período que vai de 1982 a 2012 e que engloba oito Legislaturas, na metade delas o partido deteve a maior bancada da Câmara dos Deputados $\left(48^{\mathrm{a}}, 49^{\mathrm{a}}\right.$, $50^{a}$ e $53^{a}$ Legislaturas) e, no Senado, obteve maioria em sete delas $\left(48^{\mathrm{a}}, 49^{\mathrm{a}}, 50^{\mathrm{a}}, 51^{\mathrm{a}}, 52^{\mathrm{a}}, 53^{\mathrm{a}}\right.$ e $54^{\mathrm{a}}$ Legislaturas $)$. 
No que diz respeito ao desempenho eleitoral nas eleições para a Câmara dos Deputados, o partido se manteve como o que mais elegeu deputados federais de 1986 a 1994. Nas eleições seguintes o desempenho eleitoral do partido decaiu, sendo superado primeiramente pelo PFL e pelo PSDB (em 1998), e posteriormente pelo PT e pelo PFL (em 2002), mas sempre mantendo um número expressivo de cadeiras. Em 2006, o partido voltou a eleger a maior bancada partidária da Câmara, perdendo o posto novamente para o PT nas eleições de 2010. Quanto ao Senado, o partido se manteve como a maior bancada de 1986 até o final da Legislatura iniciada em 2010. Com as eleições para a 52a legislatura em 2002, o partido passou a perder espaço, primeiramente para PT e PFL e posteriormente para PFL e PSDB em 2006, mas sempre se mantendo como a maior bancada da Casa (vide Tabela 3 ).

A nível municipal o PMDB é o partido com a maior força eleitoral do país desde o final dos anos 1980. Nas eleições de 1982 o PMDB foi superado pelo partido que sustentava o Regime Militar (o Partido Democrático Social, PDS), mas de 1988 a 2012 a sigla deteve em suas mãos a maior proporção de prefeitos eleitos ${ }^{7}$. Apesar dessa proporção ter se mantido sempre acima dos $18 \%$, ela passou a decrescer a partir de 1996, até que nas eleições de 2012, PSDB e PT foram os partidos que mais se aproximaram de seu desempenho, com $12 \%$ e $11 \%$ dos prefeitos eleitos, respectivamente (vide Tabela 4).

Esta série de indicadores evidencia o quanto o partido é relevante em nossa democracia.

Tabela 2. Número de governadores eleitos pelo PMDB (19822010 )

\begin{tabular}{lcccccccc}
\hline \hline Eleições & 1982 & 1986 & 1990 & 1994 & 1998 & 2002 & 2006 & 2010 \\
\hline \hline Governadores & 9 & 22 & 8 & 9 & 6 & 5 & 7 & 5 \\
\hline
\end{tabular}

\footnotetext{
${ }^{7}$ Em 1985 o partido também elegeu proporcionalmente o maior número de prefeitos, mas na ocasião apenas 127 cidades realizaram eleições.
} 


\begin{tabular}{lllllllll}
\hline Porcentagem & 40.9 & 95.7 & 26.9 & 33.3 & 22.2 & 18.5 & 25.9 & 18.5 \\
\hline \hline
\end{tabular}

Fontes: Tribunal Superior Eleitoral (TSE) e Nicolau (1998)

Tabela 3. Bancadas do PMDB na posse após cada eleição (1982 2010 )

\begin{tabular}{|c|c|c|c|c|c|c|c|c|}
\hline Eleições & 1982 & 1986 & 1990 & 1994 & 1998 & 2002 & 2006 & 2010 \\
\hline $\begin{array}{l}\text { Cadeiras na } \\
\text { Câmara }\end{array}$ & 200 & 260 & 108 & 107 & 82 & 74 & 89 & 79 \\
\hline Porcentagem & 41.8 & 53.6 & 21.5 & 20.8 & 16 & 14.4 & 17.3 & 15.3 \\
\hline $\begin{array}{l}\text { Cadeiras no } \\
\text { Senado }\end{array}$ & 21 & 38 & 25 & 23 & 27 & 20 & 15 & 20 \\
\hline Porcentagem & 30.4 & 79.1 & 30.8 & 28.3 & 33.3 & 24.7 & 18.5 & 24.7 \\
\hline
\end{tabular}

Tabela 4. Número de prefeitos eleitos pelo PMDB e porcentagem de cargos conquistados (1982-2012)

\begin{tabular}{lccccccccc}
\hline \hline Eleições & $\mathbf{1 9 8 2}$ & $\mathbf{1 9 8 5 *}$ & $\mathbf{1 9 8 8}$ & $\mathbf{1 9 9 2}$ & $\mathbf{1 9 9 6}$ & $\mathbf{2 0 0 0}$ & $\mathbf{2 0 0 4}$ & $\mathbf{2 0 0 8}$ & $\mathbf{2 0 1 2}$ \\
\hline \hline Prefeitos & 1.377 & 127 & 1.606 & 1.605 & 1.295 & 1.257 & 1.060 & 1.201 & 1024 \\
\hline Porcentagem & 34.9 & 63.2 & 37.5 & 33.7 & 24.1 & 22.6 & 19 & 21.6 & 18.4 \\
\hline \hline
\end{tabular}

Fontes: Tribunal Superior Eleitoral (TSE), Nicolau (1998)

* As eleições de 1985 ocorreram apenas nas capitais de estado, estâncias hidrominerais, áreas de segurança nacional e alguns novos municípios.

Apesar de obter esse desempenho eleitoral expressivo no âmbito Legislativo e mesmo tendo ocupado inúmeros postos chave nos governos eleitos a partir de 1985, a Ciência Política tem dado pouca atenção a o PMDB.

Nota-se na literatura sobre os partidos políticos brasileiros que enquanto abundam pesquisas sobre os partidos de esquerda, sendo o Partido dos Trabalhadores (PT) sem dúvida nenhuma o que mais despertou o interesse dos estudiosos (Braga, 2013, p.9; Ribeiro, 2012 , p. 10) ${ }^{8}$, os partidos localizados no âmbito oposto (no campo da direita) ou no centro do espectro partidário tem sido pouco estudados pela ciência política (Braga, 2013, p. 17; Lima Jr, 1999, p.33) - salvo raras exceções ${ }^{9}$-, mesmo cumprindo um papel fundamental nos governos pós-redemocratização e na política em

\footnotetext{
${ }^{8}$ Para uma revisão bibliográfica a respeito do Partido dos Trabalhadores, ver Menegozzo (2013).

${ }^{9}$ Como Roma (1997) e Ribeiro (2011).
} 
geral. Apesar de a agenda de pesquisa sobre os partidos políticos brasileiros ter se expandido nas últimas décadas (Braga, 2013, p.12), há muitos objetos de estudo que requerem análises mais aprofundadas (até por conta do grande número de siglas que compõem o pluripartidarismo brasileiro), sobretudo por meio dos estudos de caso de nível nacional dos partidos.

Essa tendência se reflete no fato que, com exceção de uma dissertação de mestrado sobre a estratégia e o desempenho eleitoral do PMDB de 1982 a 2012 (Oliveira 2012), até o momento de conclusão desta pesquisa não encontramos estudos de caráter monográfico que analisassem o PMDB em nível nacional ${ }^{10}$. Em sua maioria, os poucos pesquisadores que se dedicaram a estudos de caso sobre o PMDB focaram em seções regionais, sendo o Diretório Paulista o mais estudado ${ }^{11}$. Três estudos se dedicaram a analisar diferentes aspectos do partido em São Paulo (Sadek, 1989a; Melhem, 1998 e Bizzarro Neto, 2013), e um estudo tratou do seu diretório piauiense (Sá, 2011).

Sadek (1989a) analisou o desempenho do partido nas eleições de 1986 no Estado de São Paulo apresentando um importante achado acerca de suas bases eleitorais: a interiorização do voto no PMDB paulista, que contrastava com a imagem mais "urbana" que caracterizava em pleitos anteriores o MDB, seu predecessor.

O mesmo fenômeno foi explorado posteriormente por Melhem (1998) sob a ótica organizacional. Para a autora, a ascensão do grupo quercista (liderado por Orestes Quércia) ao comando do Partido no Estado de São Paulo se relacionou intimamente com essa mudança em suas bases eleitorais. A orientação mais pragmáticaeleitoral e menos ideológica desse setor, participando ativamente do seu processo organizacional naquele estado, fez com que o seu

\footnotetext{
${ }^{10}$ Os estudos de ciência política sobre o PMDB serão vistos com mais detalhes no Capítulo 1.

${ }^{11}$ Ademais, apenas um pesquisador se dedicou a estudar o PMDB em uma perspectiva comparada com outro partido. Esse estudo será apresentado no Capítulo 1.
} 
desempenho eleitoral fosse impulsionado, dando ao grupo uma posição de destaque em âmbito nacional dentro do Partido.

Por fim, Bizzarro Neto (2013) também faz uso da abordagem organizacional para compreender como a organização peemedebista e, concomitantemente, a liderança quercista sobreviveram ao declínio eleitoral do partido verificado no período estudado pelo autor (1994 a 2010). Para Bizzarro Neto, ao manter sua penetração territorial com suas bases organizacionais, o PMDB paulista adotou um modelo de organização que seria, acima de tudo, o mais eficiente para dar conta dos interesses de suas elites associadas à política local. Porém, as mudanças na configuração da política paulista, o aumento da competitividade e a "presidencialização" da política estadual produziram um realinhamento do sistema eleitoral-partidário, dentro do qual a máquina política organizada pelo PMDB não era adequada para continuar a vencer eleições.

Por sua vez, a respeito da seção piauiense do partido, o estudo de Sá (2011) cobrindo o período de 1986 a 2006 teve como foco as relações entre a atuação e o desempenho do partido na arena eleitoral daquele Estado, que teria sido impulsionado pelas arenas governamental e parlamentar. Fazendo uso do conceito de partido cartel, de Katz e Mair (1995), Sá argumenta que a manutenção do partido no Poder Executivo daquele Estado e a eleição contínua de uma forte bancada parlamentar federal geram recursos que permitiram ao partido manter uma ampla rede organizativa naquele território e vice-versa.

Como dito anteriormente, o único estudo encontrado, de caráter monográfico e que analise o PMDB em nível nacional, é a dissertação de Oliveira (2012). A autora destacou o expressivo desempenho eleitoral do partido nas eleições legislativas e a sua constante presença nos gabinetes ministeriais, de 1982 a 2012, concluindo que há uma estratégia do PMDB de se concentrar nas eleições para o Poder Legislativo, que poderia estar ligada às suas 
origens no MDB. Como principal herdeiro daquele partido, uma organização política que foi implantada e fortalecida primeiramente nas esferas estadual e municipal, o PMDB se tornou um partido descentralizado, no qual suas elites construíram sua liderança principalmente em âmbito regional. Dessa forma, desde sua origem, os partidários do PMDB concentraram seus esforços nas disputas municipais, estaduais e legislativas e, ao manterem um bom desempenho nas eleições para o Congresso, o partido se manteve também como uma das maiores bancadas nas duas Casas. Como consequência, o partido se tornou um interlocutor indispensável de qualquer governo em exercício, beneficiando-se na distribuição de ministérios no arranjo do "Presidencialismo de coalizão" ${ }^{12}$.

Para além dos poucos estudos monográficos citados, encontramos de maneira dispersa na literatura a respeito dos partidos políticos brasileiros uma série de características atribuídas ao PMDB, muitas das quais negativas. Braga (2010, p.64) caracteriza o PMDB como um partido que não possui um projeto político para o país, que seja ao mesmo tempo agregador de líderes políticos menos pragmáticos e mais comprometidos com as questões nacionais. O partido, segundo a autora, configura-se como uma grande confederação de grupos políticos estaduais, o que o torna bastante descentralizado e incapaz de compor um grupo político que o organize em caráter e âmbito nacionais. Reis (2010, p. 73), por sua vez, afirma que o partido tem uma postura excessivamente clientelista e pragmática que, segundo ele, orienta o seu enraizamento regional fragmentado. Melo (2006, p. 169) argumenta que o PMDB seria um "agregado" de interesses regionais precariamente unificados pela maximização de cargos no plano federal, um partido estritamente office seeker. Carreirão e Kinzo (2004, p.158-159) apontam que o partido passou de uma sigla com um perfil mais ou menos demarcado para um partido sem

\footnotetext{
${ }^{12}$ Sobre o presidencialismo de coalizão, ver Figueiredo e Limongi (1999).
} 
perfil algum nos anos 90. Liñan e Maiwaring (1998, p. 120) o caracterizaram como um partido catch-all durante a Constituinte, extremamente heterogêneo, com facções proeminentes variando no espectro ideológico entre a esquerda e a direita. E, ainda, Oliveira (1992, pp. 111-112), já em princípios dos anos 1990 caracterizava o PMDB como um partido "estilhaçado" e fragmentado, um partido da ordem, meramente de aglutinação de interesses.

Essas características atribuídas ao partido pela literatura contrastam com o que o PMDB se propunha a ser no momento de sua fundação. Contando com evasões numerosas da ala moderada do extinto MDB, o PMDB surgiu com uma composição de centroesquerda (Kinzo, 1988, p.210), mais homogêneo que o seu antecessor, no campo da oposição ao Regime Militar (como será mostrado nos Capítulo 2).

Contudo, no ano de 1981, o PMDB incorpora o efêmero Partido Popular (PP) pouco após a promulgação do "Pacote de Novembro" (conjunto de medidas eleitorais editadas pelo Regime Militar em novembro daquele ano). O PP possuía um projeto político distinto do PMDB, buscando construir uma identidade de partido de centro e com uma composição interna equilibrada entre políticos exemedebistas e ex-arenistas (como veremos no Capítulo 3 ).

A literatura de Ciência Política sobre o PMDB raramente lembra que o partido incorporou o PP nos seus primeiros anos de existência ${ }^{13}$ e não há qualquer registro de estudo especificamente sobre o Partido Popular. Entre os autores que citam a incorporação, dois destacaram que ela teve consequências para o PMDB. Power (1997, p. 77) menciona que o PMDB viu ser acrescida à sua composição uma pequena ala conservadora, e Benevides (1986), destaca que naquele momento teve início o processo de “deformação mórbida" do PMDB. Este estudo procura mostrar o

\footnotetext{
${ }^{13}$ Uma das poucas exceções é Ferreira (2001, p. 155), que apenas cita que a incorporação se deu apesar da resistência de alguns integrantes do PMDB, que julgavam o PP bastante identificado com o Regime por reunir vários membros egressos da antiga Arena.
} 
que efetivamente mudou no interior do PMDB com a incorporação do PP.

Assim, a presente pesquisa busca contribuir para a literatura a respeito do PMDB. Para este fim, utilizaremos como indicadores a composição de seus principais órgãos de decisão (seu Diretório Nacional e sua Executiva Nacional) e suas bancadas no Congresso Nacional.

A hipótese principal do trabalho é que, na passagem do bipartidarismo para o pluripartidarismo, houve uma homogeneização interna do PMDB em comparação ao MDB e, depois da incorporação do PP, ele ficou mais heterogêneo do que era antes. Enquanto vigorou o bipartidarismo, o antigo Movimento Democrático Brasileiro constituiu uma frente heterogênea contra o Regime Militar, "amarrado" pela legislação partidária. Porém, em 1980 , esse bloco de oposição deu origem a dois projetos políticos distintos. Enquanto uma parte dos políticos do MDB seguiu para o PMDB, uma parcela significativa dos chamados "moderados", articulada com um setor proveniente da extinta Arena, fundou o Partido Popular, um partido político que se propunha a ocupar o centro do espectro partidário. Com isso, houve uma homogeneização do PMDB no momento de sua Fundação. Porém, com a incorporação do PP ao PMDB, em 1982, surge um novo PMDB, o que chamamos de "PPMDB". Como resultado desse processo o PMDB passa a ter maior heterogeneidade interna do que tinha na ditadura, dado o perfil dos novos quadros que ingressaram no partido, o que descaracterizou o perfil homogêneo que o PMDB possuía no momento de sua fundação.

Esta pesquisa adotará, portanto, como recorte histórico os três primeiros anos do partido após o restabelecimento do pluripartidarismo, desde o seu processo de formação no final de 1979 até o seu primeiro teste eleitoral, em 1982, que será analisado no Capítulo 4. Por meio de uma análise mais detida sobre a 
composição de suas bancadas, cobrindo o período histórico aqui citado, e de seus principais órgãos de decisão, pensamos contribuir para o conhecimento de uma das organizações partidárias mais importantes da democracia brasileira, trazendo um pouco de luz sobre as características desse partido.

\section{Aspectos metodológicos}

Em um estudo de caso como este, que se propõe aprofundar o conhecimento acerca de um objeto relevante per se e importante para a história política brasileira, há uma série de fontes de pesquisa que poderiam ser utilizadas. Mantendo a tradição dos estudos monográficos sobre partidos brasileiros, usaremos neste estudo a pesquisa documental múltipla.

Como já fora apontado por Ribeiro (2010, p.32), esse método tem se mostrado o mais seguro para a realização de estudos partidários de fôlego, e foi utilizado por todas as obras que são consideradas referência no campo dos estudos monográficos ${ }^{14}$. Segundo Benevides (1981, pp. 18-19, citado em Ribeiro, 2010, p.32), somente cruzando múltiplas fontes o pesquisador consegue construir um quadro que resgata "o papel dos atores políticos, o enredo, vitórias e frustrações, as motivações, os interesses (...) situados em cena própria, mas não isolada ou estanque”. Assim, a ideia central aqui foi agregar as abordagens quantitativa e qualitativa, fazendo uso de cada método quando mais conveniente, para verificar a comprovação da hipótese por meio de uma exposição interpretativa de um período histórico do partido.

Assim, serão utilizadas quatro fontes distintas:

I. Material de imprensa coletado dos acervos digitais dos jornais Folha de S. Paulo, O Estado de S. Paulo, Jornal da Tarde, "Coluna do Castello" (publicadas no Jornal do Brasil) e da Revista Veja

\footnotetext{
${ }^{14}$ Sobre os estudos com enfoque monográfico sobre os partidos políticos brasileiros, ver Capítulo 1.
} 
cobrindo o período de 1 de dezembro de 1979 a 31 de dezembro de 1982 .

II. Documentos do partido coletados do acervo mantido pela Fundação Ulysses Guimarães (antiga Fundação Pedroso Horta, "entidade de cooperação do Partido, instituída com a finalidade de desenvolver projetos de pesquisa, doutrinação e educação política"; art. 53 do Estatuto Partidário), assim como do acervo mantido pelo Diretório paulista do partido ${ }^{15}$.

III. Entrevistas de História Oral, documentos de arquivos pessoais e verbetes do Dicionário Histórico-Biográfico Brasileiro, mantidos pelo Centro de Pesquisa e Documentação de História Contemporânea do Brasil (CPDOC/FGV).

IV. Dados eleitorais obtidos através do Tribunal Superior Eleitoral (TSE), do Centro de Documentação e Informação da Câmara dos Deputados (CEDI) e do Serviço de Informação ao Cidadão do Senado Federal, a respeito das eleições de 1982.

\section{Organização do texto}

Este estudo se divide em quatro capítulos.

No Capítulo 1 apresentamos os estudos produzidos pela literatura nacional de Ciência Política que adotaram o enfoque monográfico para estudar os partidos políticos brasileiros. Ademais, apresentamos também uma revisão dos estudos que foram publicados a respeito do PMDB e demonstramos de que maneira este estudo representa algo novo para o campo de estudos sobre o partido.

Em seguida, no Capítulo 2, abordamos o período de fundação do PMDB (ou de "refundação" do MDB), buscando reconstruir analiticamente o seu processo de formação e a sua relação com os outros partidos e com o Regime Militar. Ao considerar as divisões

\footnotetext{
${ }^{15}$ Agradeço à funcionária Valéria Lossani por me apresentar o acervo da Fundação no Diretório paulista do PMDB.
} 
internas herdadas do MDB, demonstramos que houve uma maior perda de quadros no seu campo moderado (rumo ao PP e PDS) do que na ala mais à esquerda do extinto partido (rumo ao PT e PDT), evidenciando o caráter mais homogêneo do PMDB em relação ao que foi o MDB de 1966-1979.

No Capítulo 3 analisamos o impacto do processo de incorporação do Partido Popular ao PMDB. Para esse fim, apresentamos primeiramente o processo de fundação do PP e o seu perfil ideológico e organizacional. Essa análise é fundamental para compreendermos o que o diferenciava do PMDB e o que esses novos quadros representaram para o Partido quando decidiu aceitar a sua incorporação, após o anúncio do "Pacote de Novembro" de 1981. Demonstramos nesse capítulo as consequências dessa assimilação tanto para uma maior desfiguração regional do partido quanto para a composição dos seus dois principais órgãos internos de decisão: o Diretório Nacional e a Executiva Nacional.

No Capítulo 4 apresentamos outro indicador empírico que nos permite analisar o quanto a incorporação do PP contribuiu para a heterogeneidade interna do PMDB. Como veremos no Capítulo 2, o PMDB em sua gênese é um partido com fortes bases parlamentares. Em seu primeiro teste eleitoral após o restabelecimento do pluripartidarismo, em 1982, o partido mantém essa característica, tendo o melhor desempenho eleitoral entre os partidos de oposição e aumentando o tamanho da sua bancada na Câmara dos Deputados. A partir dessa constatação, os resultados do PMDB nas eleições para o Congresso Nacional em 1982 se tornam um locus importante para analisarmos o impacto da incorporação para a representação parlamentar do partido. Nesse sentido, fazendo uso de novos dados acerca da filiação partidária prévia dos eleitos pelo partido para as duas Casas, evidenciamos como a incorporação do PP contribuiu para aumentar a heterogeneidade interna do PMDB nos seus primeiros anos de funcionamento legal. 
Por fim, nas considerações finais, fazemos uma síntese dos resultados encontrados nesta pesquisa. 


\section{Capítulo 1 \\ 0 enfoque monográfico e os partidos políticos brasileiros}

No campo dos estudos sobre os partidos políticos brasileiros, esta pesquisa se situa no âmbito dos estudos monográficos, cujo enfoque se detém sobre um partido político, por meio de abordagem nacional ou regional. Os primeiros estudos que adotaram esse enfoque emergiram na ciência política nacional no início dos anos 1980. Desde então, porém, apesar da agenda de estudos sobre a temática partidária ter se ampliado e se tornado mais complexa, (Braga, 2013, p.3 $)^{16}$, o enfoque monográfico passou a ser menos utilizado. Por conseguinte, muitos dos partidos políticos, sobretudo aqueles organizados após o restabelecimento do pluripartidarismo em 1979, ainda carecem de estudos que adotem essa abordagem. O PMDB representa um desses casos e será o objeto desta pesquisa.

Diante de tais considerações, o primeiro objetivo deste capítulo é apresentar os estudos monográficos existentes na Ciência Política brasileira, com destaque para dois aspectos que são comuns a todos e que se mostrarão presentes também neste trabalho. O primeiro deles é o recurso à narrativa histórica, indispensável para reconstruir as transformações pelas quais um partido atravessa ao longo de sua existência. O segundo aspecto consiste nas fontes de pesquisa passíveis de serem utilizadas pelos estudiosos, os quais, em sua totalidade, recorreram à pesquisa documental múltipla.

Em particular, serão apresentados neste capítulo os poucos estudos monográficos realizados sobre o MDB/PMDB, e quais foram suas principais conclusões. O objetivo é demonstrar que não

\footnotetext{
${ }^{16}$ Não cabe aqui fazer uma revisão de todos os enfoques utilizados pela Ciência Política brasileira para o estudo dos partidos políticos. Para uma revisão ampla da literatura nacional e da atual agenda de pesquisas nesse campo, ver Lima Jr., Schmitt e Nicolau (1992), Lima Jr. (1999), Nicolau (2010), Braga (2013) e Amaral (2013).
} 
há qualquer estudo que tenha se proposto a analisar o que mudou na composição interna do partido após a incorporação do PP, uma lacuna que esta pesquisa se propôs a preencher.

1. Os estudos monográficos na Ciência Política brasileira

Como dito anteriormente, este estudo pretende se inserir na tradição de estudos monográficos produzidos pela Ciência Política sobre os partidos políticos brasileiros. Antes de adentrar na parte empírica deste estudo, faz-se necessário apresentar a gama de estudos que se inserem nessa tradição e quais são os seus aspectos mais gerais, que serão reproduzidos neste estudo sobre o PMDB.

A tradição de estudos monográficos teve início no começo da década de 1980 na Ciência Política brasileira, período no qual foram publicados os primeiros estudos que adotaram esse enfoque. Esses primeiros estudos focaram-se, principalmente, nos partidos organizados durante o regime democrático de 1945 a 1964, período sobre o qual produziu-se a maior quantidade de pesquisas sobre a temática partidária ${ }^{17}$.

Os três principais partidos daquele período foram estudados por meio da abordagem monográfica, a saber, a União Democrática Nacional (UDN), o Partido Trabalhista Brasileiro (PTB) e o Partido Social Democrático $(P S D)^{18}$. Ademais, outras três siglas daquela conjuntura também foram objeto de estudo monográfico: o Partido Social Progressista (PSP), o Partido Democrata Cristão (PDC) e o Partido Comunista Brasileiro $(\mathrm{PCB})^{19}$.

Posteriormente, a partir do final da década de 1980, os partidos existentes durante o bipartidarismo vigente no Regime Militar e

\footnotetext{
${ }^{17}$ Em levantamento preliminar realizado em 2004, Jairo Nicolau (2004, p.85) apontou que mais de 130 trabalhos haviam sido produzidos sobre o assunto até então. Para uma compilação ampla dos estudos publicados sobre esse período até o ano de 1978 ver Lamounier e Kinzo (1978) e para os estudos publicados entre 1978 e 1992 ver Lima Jr. Schmitt e Nicolau (1992).

${ }^{18}$ Sobre a UDN ver Benevides (1981) e Picaluga (1980). Sobre o PTB ver Loyola (1980), Benevides (1989), D’Araujo (1996) e a dissertação de Martins Jr. (2001). Sobre o PSD ver Hippolito (2012) e Lippi (1972).

${ }^{19}$ Sobre o PSP ver Sampaio (1982), sobre o PCB ver o estudo de Brandão (1997), e sobre o PDC ver Vianna (1978).
} 
alguns dos partidos que emergiram após o restabelecimento do pluripartidarismo também passaram a ser estudados sob o enfoque monográfico. Surgiram obras sobre o Movimento Democrático Brasileiro (MDB) e a Aliança Renovadora Nacional (Arena) ${ }^{20}$. Já com relação aos partidos organizados após a Reforma Partidária de 1979, como dito na Introdução, a maior parte dos estudos teve como objeto o Partido dos Trabalhadores (PT) ${ }^{21}$. Salvo raras exceções, há poucos estudos sobre os partidos de centro ou de direita do período pluripartidário ${ }^{22}$. As poucas exceções são os estudos realizados sobre o Partido da Social Democracia Brasileira $(\mathrm{PSDB})^{23}$, sobre o Partido da Frente Liberal (PFL) ${ }^{24}$, sobre o Partido Progressista Brasileiro (PPB $)^{25}$, e sobre o Partido do Movimento Democrático Brasileiro $(\mathrm{PMDB})^{26}$.

De maneira geral, há dois aspectos comuns à maioria dos estudos monográficos que devem ser destacados, pois terão serventia a este estudo de caso sobre o PMDB: o recurso à narrativa histórica e o uso de múltiplas fontes de pesquisa.

De forma breve, podemos apontar que o recurso à narrativa histórica é essencial para os estudos monográficos ${ }^{27}$. Os partidos não são estruturas monolíticas, imutáveis. Como qualquer organização, eles são estruturas em movimento, que sofrem evoluções, que se modificam no tempo, e que reagem às mudanças externas nos "ambientes" nos quais estão inseridos e atuam (Panebianco, 2005, p.91). Essas transformações pelas quais um partido atravessa não podem ser analisadas apenas em um momento

\footnotetext{
${ }^{20}$ Sobre o MDB ver Kinzo (1988) e sobre a Arena ver Grinberg (2009).

${ }^{21}$ Para uma revisão ampla dos estudos produzidos sobre o PT, ver Menegozzo (2013). Entre os estudos com enfoque monográfico destaco Meneguello (1989), Keck (1991), Brandão (2003), Ribeiro (2010), e Secco (2011), entre outros.

${ }^{22}$ A literatura especializada tem classificado, unanimemente, o PMDB como um partido de centro. Ver Limongi e Figueiredo (1999), Melo (2000), Rodrigues (2002), Fleischer (2007), Pasquarelli e Bizzarro Neto (2012), entre outros.

${ }^{23}$ Roma (1997, 2002).

${ }^{24}$ Ribeiro (2011).

${ }^{25}$ Almeida (2004).

${ }^{26}$ A serem analisados na próxima seção.

27 Para uma análise ampla sobre a relação entre narrativa histórica e ciência política, ver Perissinoto (2013).
} 
pontual, pois elas podem se dar ao longo de anos, ou até mesmo décadas, por meio de tendências de médio ou de longo prazo. Assim, apenas por meio da reconstrução da história do partido (ou de uma parte dela) o pesquisador tem a possibilidade de observar as transformações ocorridas no seu interior e as diferentes posições que foram adotadas pelos seus dirigentes ao longo de sua trajetória.

O segundo aspecto a ser destacado sobre os estudos monográficos é o uso de múltiplas fontes de pesquisa, com a combinação de métodos quantitativos e qualitativos. Somente por meio da compilação de uma ampla gama de dados e de documentos históricos dos partidos, somados às interpretações e declarações dos dirigentes políticos ("deixar os atores internos falarem", nas palavras de Ribeiro, 2010, p. 31), os pesquisadores podem reconstruir o rico mosaico que compreende a história do partido estudado.

Nesse sentido, todas as análises que adotaram o enfoque monográfico recorreram à "pesquisa documental múltipla", tendo como fontes, em maior ou menor medida, o noticiário de imprensa dos principais jornais e revistas em circulação (o que passou a ser facilitado a partir do momento em que a grande imprensa passou a disponibilizar seus acervos on-line $e^{28}$ ); o acervo mantido pelos partidos em suas Fundações ${ }^{29}$, em sua sede nacional ou em seus diretórios regionais (como os livros de atas de reuniões); entrevistas com os políticos do partido estudado (coletadas pessoalmente ou por meio de terceiros); documentos públicos emitidos pelos partidos, como seus Programas, Estatutos e Manifestos; dados estatísticos em geral, que subdividem-se em dados eleitorais e sobre coligações (coletados no Tribunal Superior

\footnotetext{
${ }^{28}$ Como exemplos, os acervos digitais do jornal O Estado de S. Paulo (http://acervo.estadao.com.br/), da Folha de S. Paulo (http://acervo.folha.com.br/fsp), e da Revista Veja (http://veja.abril.com.br/acervodigital/).

${ }^{29}$ Os principais partidos políticos brasileiros possuem Institutos ou Fundações que representam seus órgãos de formação política. Apenas a título de exemplo, o PSDB possui o Instituto Teotônio Vilela, o PMDB possui a Fundação Ulysses Guimarães, e o PT possui a Fundação Perseu Abramo.
} 
Eleitoral ou nos Tribunais Regionais Eleitorais), e dados sobre as filiações partidárias (coletados nas Assembleias Legislativas ou através de publicações oficiais, como os Anais e Diários do Congresso e do Senado); e, por fim, os acervos mantidos pelas instituições de pesquisa, tal como o Centro de Pesquisa e Documentação de História Contemporânea do Brasil (CPDOC/FGV).

Esses dois aspectos destacados, comuns a todos os estudos monográficos, também serão vistos nesta pesquisa. Como dito na Introdução, a comprovação da hipótese deste estudo se dará por meio de uma exposição interpretativa de um período histórico do PMDB (de 1979 a 1982). Para tal fim, a pesquisa documental múltipla se mostra fundamental, por meio da qual se torna possível reconstruir diferentes aspectos da trajetória do partido e analisálos sob a luz da Ciência Política.

2. O enfoque monográfico e o MDB/PMDB

Como dito na Introdução, há poucos estudos monográficos sobre o $\mathrm{PMDB}^{30}$, e a mesma observação se estende ao seu antecessor, o MDB. A pequena quantidade de pesquisas sobre o objeto aqui estudado, como ficará claro nesta seção, revela que há uma série de lacunas a serem preenchidas pela Ciência Política no estudo do PMDB e, o objetivo da presente pesquisa é preencher uma delas.

Kinzo (1988) foi a primeira pesquisadora a se dedicar a pesquisar o MDB. Em seu estudo “Oposição e autoritarismo: gênese e trajetória do MDB (1966-1979)", a autora realizou o primeiro estudo de caso de que se tem registro acerca daquela organização, tornando-se também um marco nos estudos monográficos devido à

\footnotetext{
${ }^{30}$ Não apresentaremos neste tópico os livros publicados sobre o PMDB escritos pelos seus próprios quadros políticos, de caráter mais ideológico e pouco científico, ou os livros de cunho jornalístico. Entre eles cito Bresser Pereira (1987), Melhem e Russo (1987), Leonelli e Oliveira (2004) e Delgado (2006).
} 
quantidade de aspectos do partido abordados ${ }^{31}$. A autora destaca que, no momento de sua fundação, o MDB se caracteriza como uma confluência das mais variadas tendências, o que se deu pelo fato de não ter havido uma cisão claramente definida entre os partidos que formavam o sistema partidário pré-66 (idem, p. 31) ${ }^{32}$. Essa ampla gradação de posições ideológicas no MDB se manteria ao longo de toda a sua existência, pelo fato de o partido ter sido, ao lado da Arena, a única organização legal permitida pelo regime. Mas não apenas oposicionistas ao Regime fizeram parte do MDB. Segundo Kinzo, havia também aqueles que, devido a rivalidades locais, tinham migrado para o MDB unicamente para ser oposição aos seus arqui-inimigos que haviam se apossado da Arena antes deles (idem, pp. 55-56). Dessa forma, coexistiram no partido, até a sua extinção, conservadores, liberais, socialdemocratas, reformistas e todas as tonalidades da esquerda (boa parte delas futuramente herdadas pelo PMDB).

Além do estudo de Kinzo, há outros três estudos monográficos que se dedicaram a analisar diferentes aspectos do MDB/PMDB, restritos à sua atuação em São Paulo (Sadek, 1989a; Melhem, 1998 e Bizzarro Neto, 2013), um estudo sobre o seu diretório piauiense (Sá, 2011), e um único estudo que adota uma perspectiva nacional para analisar o PMDB (Oliveira, 2012).

Em se tratando dos estudos sobre o diretório paulista do partido, no primeiro deles, Sadek (1989a) destacou o processo de interiorização do voto no PMDB paulista. Para a autora, o perfil geográfico do voto no partido nas eleições para o cargo de Governador do Estado de São Paulo, em 1986, contrasta com a imagem que caracterizava o MDB nos pleitos anteriores. Enquanto o MDB teve uma base eleitoral mais forte nas áreas mais

\footnotetext{
${ }^{31} \mathrm{O}$ pioneirismo das pesquisas de Kinzo foi destacado por Argelina Figueiredo, em sua homenagem àquela pesquisadora, publicada na Revista Dados - Revista de Ciências Sociais, Rio de Janeiro, vol. 51, n. 2, 2008, pp. 269-270.

32 O Ato Institucional N. 2, em Outubro de 1965, e o Ato Complementar N. 4, em dezembro do mesmo ano, extinguiram os partidos então vigentes e instituíram o bipartidarismo.
} 
urbanizadas e industrializadas, sobretudo na região da grande São Paulo, os votos no candidato do PMDB em 1986, Orestes Quércia, foram mais dispersos nas cidades do interior do Estado, com população predominantemente rural. Quércia venceu na maioria delas, ao mesmo tempo que perdeu na capital do Estado, representando uma perda substancial das antigas bases eleitorais do MDB. Evidenciava-se, assim, uma mudança nas bases eleitorais do partido, ao que a autora denominou "interiorização" do voto no PMDB.

O fenômeno da interiorização do voto no PMDB foi posteriormente estudado por Melhem (1998), porém, sob a ótica do processo organizacional e das disputas internas que marcaram a seção regional paulista do MDB/PMDB, de 1965 a 1988. A autora argumenta que a orientação pragmática-eleitoral era o que movia o MDB paulista, e que isso acabaria por se refletir no PMDB. Ainda segundo ela (1998, pp.15-16), a manutenção das eleições para parlamentares e prefeitos durante o Regime Militar atraiu quadros para atuar dentro do MDB, porém, nem todos esses quadros estavam ideologicamente comprometidos com a oposição ao regime autoritário. Alguns eram meros adversários dos políticos filiados à Arena, que faziam oposição por simples conveniência, como já dito. Essas mesmas lideranças tiveram um papel crucial na organização do partido nas pequenas cidades do interior, em especial o papel cumprido por Orestes Quércia. O político procurou se beneficiar do processo de organização do partido pelo interior, congregando ao seu redor uma série de lideranças locais com perfil menos programático e mais pragmático, dando origem ao chamado "quercismo", corrente que passa a ter destaque no controle do partido em nível regional e posteriormente nacional.

No que tange à composição interna do MDB, para Melhem (1998, pp. 70-71) o grupo de parlamentares fundadores do partido era bem heterogêneo, e poderiam estar momentânea ou definitivamente posicionados na oposição (por razões pessoais, 
ideológicas, históricas, ocasionais, etc.), também apresentando trajetórias políticas diversificadas (por vezes conflitantes) e diferentes concepções de oposicionismo (algumas beirando o adesismo, outras, ao contrário, pressionando por uma oposição radical). Grosso modo, tanto para Melhem (idem, p. 88) quanto para Kinzo (1988, p. 57), todos esses setores que compunham o interior do MDB eram agrupados em torno de "autênticos" e "moderados".

Por fim, cabe citar aqui o estudo de Bizzarro Neto (2013), único estudo, dos três aqui citados, a se dedicar exclusivamente ao PMDB paulista, sem tomar em conta o seu antecessor, o MDB. Seguindo a mesma linha de investigação de Melhem, o autor analisou o aspecto organizacional do partido no Estado de São Paulo, no período de 1994 a 2010. Seu objetivo foi compreender como a organização peemedebista e, concomitantemente, a liderança quercista, sobreviveram ao declínio eleitoral do partido, verificado no período estudado, naquele Estado de maneira mais acentuada do que no nível nacional. A abordagem organizacional adotada pelo autor considera as variáveis organizacionais como sendo as variáveis intervenientes para explicar a trajetória eleitoral e política do partido. Segundo Bizzarro Neto, ao manter sua penetração territorial com suas bases organizacionais, o PMDB paulista adota um modelo de organização que seria acima de tudo o mais eficiente para dar conta dos interesses de suas elites, construindo uma máquina política fortemente associada à política local (p. 159). O autor transita entre os diferentes modelos interpretativos sobre os partidos políticos ao concluir que uma análise a respeito do PMDB não pode reduzi-lo apenas ao modelo organizacional, devendo levar em conta também fatores como: lealdades, status, poder partidário e disputas internas desta seção regional.

Ainda no campo dos estudos sobre diferentes seções regionais do PMDB, cabe aqui citar o estudo de Sá (2011) a respeito da seção 
piauiense do partido. Sua pesquisa está focada nas relações entre a atuação e o desempenho do partido na arena eleitoral, impulsionado pelas arenas governamental e parlamentar, cobrindo o período de 1986 a 2006. Fazendo uso do conceito de partido cartel, de Katz e Mair (1995), o autor apresenta o desempenho eleitoral do partido baseando-se em dados do TRE-PI para argumentar que a manutenção do partido no poder Executivo do estado, assim como a eleição de uma forte bancada parlamentar federal, permitiram ao partido a obtenção de fundos para manter uma ampla rede organizativa naquele estado e vice-versa.

Como dito na Introdução, a única pesquisa encontrada a adotar uma abordagem nacional para o estudo do PMDB foi Oliveira (2012). A autora apresenta o desempenho eleitoral do partido no período de 1982 a 2010 e a participação de seus membros nos ministérios e secretarias dos referidos governos pósredemocratização. Por meio do estudo de seu desempenho eleitoral e de sua presença nos governos, a autora procura analisar a estratégia do partido e as razões que o levaram a focar seus esforços nas eleições legislativas, assim como nas esferas estaduais e municipais.

Segundo a autora, esta estratégia estava diretamente ligada ao fato do PMDB ter sido o principal herdeiro do MDB, uma organização política que foi implantada e fortalecida primeiramente nas esferas estadual e municipal. As elites do extinto partido construíram sua liderança principalmente no âmbito regional e municipal, por serem estas as esferas para as quais o Regime Militar manteve as eleições diretas. Dessa maneira, desde sua origem, os partidários do PMDB herdaram esse aspecto do seu antecessor e concentraram seus esforços nas disputas municipais, estaduais e legislativas. Nesse sentido, ao manterem um bom desempenho nas eleições para o Congresso, o partido se manteve também como uma das maiores bancadas nas duas Casas, fazendo com que os outros grandes partidos tenham certa dependência do 
PMDB no momento de montar uma coalizão de governo, qualquer que seja o partido exercendo mandato no poder Executivo Nacional.

Nesta seção, cabe ainda lembrar do estudo de Ferreira (2001), que, ao analisar o federalismo brasileiro, compara a descentralização do PMDB com a de outro partido, o Partido da Frente Liberal (PFL), focando-se no período de 1982 a 2000. A autora argumenta que o federalismo poderia ser um elemento balizador de suas disputas internas, assim como seu posicionamento frente ao governo federal. A autora apresenta as clivagens regionais do partido a partir do governo Sarney (1985) ou seja, sem apresentar uma análise sobre o período histórico coberto por esta pesquisa - e evidencia a dificuldade do partido em criar uma identidade própria mesmo sendo o partido mais antigo do país.

Como demonstramos neste capítulo, há uma tradição de estudos monográficos sobre os partidos políticos brasileiros; porém, apesar dela, poucos pesquisadores se dedicaram ao estudo aprofundado do PMDB. Em sua maioria, os estudos existentes sobre o partido abordaram uma de suas seções regionais e, com exceção de um estudo, não há qualquer pesquisa que adote uma abordagem nacional. Ademais, nenhum dos estudos aqui citados adotou como recorte histórico o período de 1979 a 1982, ou seja, os primeiros anos de formação do partido após o restabelecimento do pluripartidarismo, período este no qual se deu o processo de incorporação do PP.

Os únicos estudos a citarem esse processo foram as pesquisas de Ferreira (2001, p. 155) e Oliveira (2012, pp. 51-51), que apontam apenas que a incorporação se deu apesar da resistência de alguns integrantes do PMDB, que julgavam o PP bastante identificado com o Regime por reunir vários membros egressos da antiga Arena. Mas 
suas análises não vão além disso, haja visto que as autoras se focam no período posterior às eleições de 1982. Ou seja, não há qualquer estudo que tenha analisado as consequências do processo de incorporação do PP para o PMDB, homologado pelo TSE em fevereiro de 1982 , e que será o foco desta pesquisa.

Dessa forma, fica evidente a carência de estudos que abordem o processo de formação do partido ${ }^{33}$, assim como de seus aspectos internos, tal como a composição de suas alas e de seus diferentes órgãos de direção. Esta pesquisa representa um primeiro passo para preencher essa lacuna, cobrindo um pequeno, porém importante, período da história do PMDB.

${ }^{33}$ Cabe destacar também que, entre os partidos que surgem em 1980, não encontramos na literatura qualquer estudo que trate do processo de formação de outras quatro das seis siglas que surgem naquele momento: o PDT, o PTB, o PDS e o PP. 


\section{Capítulo 2 \\ 0 processo de refundação do MDB: surge o PMDB (1979-1980)}

Como vimos no capítulo anterior, a literatura nacional sobre os partidos brasileiros não apresenta qualquer estudo que trate do processo de formação do PMDB imediatamente após o restabelecimento do pluripartidarismo ${ }^{34}$. O objetivo deste capítulo será preencher essa lacuna, analisando o período de formação do PMDB (ou de "refundação do MDB") e o seu primeiro ano de funcionamento legal após o sancionamento da reforma Partidária de 1979. Segundo Panebianco (2005, p. 311), a análise de um partido político deve necessariamente retroceder a sua fase de formação, reintroduzindo na posição central, e não marginal, a dimensão histórica. Em função disso, a reconstrução da história do PMDB naquele período (1979-1980) constitui a base indispensável para o conhecimento do que foi o partido no momento inicial de sua formação.

Como demonstraremos neste capítulo, o PMDB em sua gênese é fundado com uma forte base parlamentar, ainda que, na passagem do bipartidarismo para o pluripartidarismo tenha ocorrido uma transferência de políticos do MDB para o PDS (a chamada ala dos "adesistas") e de parte significativa dos "moderados" para o PP (que procura se colocar no centro do espectro partidário, como veremos no Capítulo 3). Além disso, a manutenção de um bloco de esquerda dentro do PMDB após sua (re)fundação (um campo que teve menores evasões), contribuiu para que o partido tivesse um perfil mais homogêneo naquele contexto do que tivera o MDB no momento de sua extinção.

\footnotetext{
${ }^{34}$ A única autora a levantar algumas questões sobre os primeiros anos do partido é Ferreira (2001), que ainda assim o faz em perspectiva comparada com o PFL, preterindo o período de 1979 a 1982 .
} 


\section{Conjuntura histórica e o novo cenário partidário}

O Projeto de Reforma Partidária enviado ao Congresso em 18 de outubro de 1979 (estabelecendo uma nova legislação para a formação de partidos políticos) deu início a um processo de realinhamento de toda a classe política nacional ${ }^{35}$. O Projeto forçava os políticos a se acomodarem em um novo cenário partidário que fatalmente surgiria, numa nova conjuntura, mais liberalizante, e na qual haviam sido reincorporadas ao cenário político nacional muitas das lideranças políticas anistiadas poucos meses antes por meio da Lei de Anistia (algumas delas figuras de expressão no cenário nacional pré-64 $4^{36}$ ). Apesar das tentativas de alguns líderes emedebistas de manter a oposição unida ${ }^{37}$, os quadros que formavam o MDB passaram a construir outros partidos políticos, que surgiriam oficialmente após o sancionamento da nova lei.

Em 20 de dezembro de 1979, o então presidente João Baptista Figueiredo sanciona a Lei n. 6.767, extinguindo os partidos criados com base no Ato Complementar $\mathrm{n}^{\circ} 4$, de 20 de dezembro de 1965, por não preencherem os requisitos da nova lei ${ }^{38}$. Em outras palavras, foram extintos os partidos vigentes e com eles o bipartidarismo de MDB e Arena, impondo-se a articulação de novos partidos políticos até que a lei fosse efetivamente regulamentada pelo TSE $^{39}$. Naquele momento de passagem do bipartidarismo para o pluripartidarismo parte dos políticos do extinto MDB não se

\footnotetext{
${ }^{35}$ Tal como fizeram o Ato Institucional N. 2, em Outubro de 1965, e o Ato Complementar N. 4, em dezembro do mesmo ano, que instituíram o bipartidarismo.

${ }^{36}$ Como, por exemplo, Leonel Brizola, Luís Carlos Prestes e Miguel Arraes. Sobre a anistia política de 1979 ver Mezarobba (2006).

${ }^{37}$ Segundo Kinzo (1988, p. 207), o ano de 1979 iniciava-se com o MDB dividido entre os que defendiam a abertura do leque partidário e os que estavam determinados a dar continuidade ao MDB como única frente oposicionista. Com a aceleração do processo de criação de outros partidos, ficaria claro quais partidários do MDB tomaram cada uma dessas posições.

${ }^{38}$ A lei em sua íntegra encontra-se no link www2.camara.leg.br/legin/fed/lei/1970-1979/lei-6767-20dezembro-1979-357280-publicacaooriginal-1-pl.html acessado em 27/06/2013.

${ }^{39}$ Para uma cronologia do debate sobre a reformulação partidária de 1978 até meados de 1979, ver Kinzo (1980).
} 
transfere para seu principal sucedâneo, o PMDB, e passam publicamente a ser filiados a outros partidos que surgiam.

A Reforma Partidária de 1979 tinha como objetivo de fundo fragmentar a oposição, provocando a desintegração do MDB, mas sem fragmentar a Arena (Kinzo, 1988, p.205). Como resultado dessa estratégia, surgiram seis novos partidos: o Partido Democrático Social (PDS, conhecido no jargão popular como “Arenão"), o Partido do Movimento Democrático Brasileiro (PMDB), o Partido Popular (PP), os dois Partido Trabalhista Brasileiro (o PTB brizolista, posteriormente chamado Partido Democrático Trabalhista, "PDT", e liderado por Leonel Brizola, e o PTB varguista, liderado por Ivete Vargas, que vence a disputa pela sigla) e o Partido dos Trabalhadores (PT) ${ }^{40}$. Todos os partidos surgiram com uma base parlamentar mínima (uma exigência da nova legislação, como será visto na seção 3 deste capítulo), e apenas o PT possuía um processo de formação mais externo do que interno ao Parlamento ${ }^{41}$.

A então nova composição partidária do Congresso nos permite visualizar qual o perfil daqueles que formavam os novos partidos e qual a sua respectiva base parlamentar no momento de sua fundação. Os três partidos com maior força no Congresso passaram a ser o PDS, o PMDB e o PP. O PDS tornava-se o novo partido governista, demonstrando o sucesso da estratégia do governo em manter seus parlamentares articulados em apenas uma legenda. Na Câmara, o partido surgia com 215 Deputados, sendo formado por $90 \%$ de ex-arenistas e $10 \%$ de ex-emedebistas. No Senado, dos seus 36 parlamentares, $97 \%$ foram ex-arenistas e apenas $3 \%$ exemedebistas. Já o PMDB tornava-se o maior partido de oposição no Congresso. Na Câmara ele é formado por 115 políticos, 95\% de exemedebistas e $5 \%$ de ex-arenistas. No Senado, dos seus 22 filiados,

\footnotetext{
${ }^{40}$ A respeito das propostas de criação de outros partidos nos anos de 1978-79, ver Kinzo (1980).

${ }^{41}$ Para uma análise da formação do PT e o seu aspecto mais externo do que interno ao sistema político, ver Keck (1991).
} 
o partido era composto por $91 \%$ de ex-emedebistas e $9 \%$ de exarenistas. Por sua vez o PP era o partido que apresentava em sua formação uma composição mais equilibrada entre os dois partidos que marcaram o período de 1966-1979, demonstrando seu caráter centrista $^{42}$. Na Câmara dos Deputados, $59 \%$ de sua bancada era composta por ex-emedebistas e $41 \%$ de ex-arenistas, computando um total de 69 Deputados. No Senado a proporção era exatamente de $50 \%$ para ex-emedebistas e $50 \%$ de ex-arenistas, em uma bancada formada por oito Senadores.

Tabela 5. Composição da Câmara dos Deputados após a Reforma Partidária de 1979

\begin{tabular}{lrrrrr}
\hline \hline \multicolumn{7}{c}{ Partidos dissolvidos } & & Total \\
\hline \hline Novos partidos & Arena & $\mathrm{N}$ & $\mathrm{N}$ & $\mathrm{N}$ \\
\hline PDS & $\mathrm{N}$ & $\%$ do total & $\mathrm{N}$ & $\%$ do total & $\mathrm{N}$ \\
\hline PMDB & 193 & $89,77 \%$ & 22 & $10,23 \%$ & 215 \\
\hline PP & 6 & $5,22 \%$ & 109 & $94,78 \%$ & 115 \\
\hline PTB & 28 & $40,58 \%$ & 41 & $57,97 \%$ & 69 \\
\hline PDT & 3 & $75 \%$ & 1 & $25 \%$ & 4 \\
\hline PT & 0 & $0 \%$ & 10 & $100 \%$ & 10 \\
\hline Indecisos & 0 & $0 \%$ & 5 & $100 \%$ & 5 \\
\hline Total & 1 & & 1 & & 420 \\
\hline \hline
\end{tabular}

Fonte: Schmitt (2000, p. 51)

Tabela 6. Composição do Senado Federal após a Reforma Partidária de 1979

\begin{tabular}{lrrrrr}
\hline \hline \multicolumn{7}{c}{ Partidos dissolvidos } \\
\hline Arena & $\mathrm{N}$ & $\%$ do total & $\mathrm{N}$ & \% do total & \\
\hline \hline Novos partidos & 35 & $97 \%$ & 1 & $3 \%$ & 36 \\
\hline PDS & 2 & $9 \%$ & 20 & $91 \%$ & 22 \\
\hline PMDB & 4 & $50 \%$ & 4 & $50 \%$ & 8 \\
\hline PP & & & 1 & & 1 \\
\hline Indecisos & 41 & 26 & & 67 \\
\hline Total & & & & & \\
\hline \hline
\end{tabular}

Fonte: Schmitt (2000, p. 51)

\footnotetext{
${ }^{42}$ O caráter centrista do PP será demonstrado no próximo capítulo.
} 
Os dados nos mostram que há uma parcela significativa de parlamentares do extinto MDB que se transfere para o PP e para o PDS no momento de fundação desses partidos. Na Câmara dos Deputados, um total de 63 políticos ex-emedebistas se transferem para essas agremiações: 22 se filiam ao PDS e 41 ao PP. Um ponto interessante é que a bancada emedebista fluminense se tornou majoritariamente pertencente ao PP pois a corrente chaguista do MDB (liderada pelo governador fluminense Chagas Freitas) migrou em peso para esse partido (dos 35 deputados que o MDB possuía no estado do Rio de Janeiro, 19 foram para o PP) ${ }^{43}$. Entre os deputados que se transferem do MDB diretamente para o novo partido governista, muitos eram da bancada paulista ligada ao então governador Paulo Maluf. Foi o caso dos deputados Adalberto Camargo, Antônio Zacharias, Athie Coury, Jairo Maltoni, João Paulo Arruda e José Camargo, mas há também políticos de outros estados que migraram da oposição para o governo, como o Deputado fluminense Léo Simões.

As defecções do MDB para os outros três partidos (PT, PTB e PDT) no momento de formação do pluripartidarismo foram significativamente menores. Apenas 16 Deputados se filiaram a essas agremiações e não há qualquer Senador que tenha migrado para eles. Levando em conta que os dois partidos mais claramente identificados com a oposição, PT e PDT ${ }^{44}$, conseguiram atrair apenas alguns deputados emedebistas ${ }^{45}$, e que o número de evasões foi maior entre os quadros conservadores, Kinzo (1988, p.210) argumenta que esse novo alinhamento indicava que, de certa forma, o PMDB emergia com uma composição de centro-esquerda ${ }^{46}$. Sob essa perspectiva, o partido surgia também com uma composição

\footnotetext{
${ }^{43}$ Sobre o fenômeno do "chaguismo", ver Diniz (1982) e o verbete "Chagas Freitas" do Acervo CPDOV/FGV

${ }^{44}$ O PTB, fundado por Ivete Vargas, apresenta uma grande indefinição nos seus primeiros anos chegando a votar com o PDS em matérias importantes no ano de 1981. Power (1997, p.76) classifica o partido naquele período como "um pequeno partido à direita do centro" (tradução minha).

${ }^{45}$ Exemplos de políticos que se transferem do MDB para o PDT em 1980 (então ainda conhecido como PTB Brizolista) são os deputados baianos Jorge Viana, Hilderico de Oliveira e Roque Aras.

${ }^{46}$ A composição da primeira Comissão Executiva Nacional eleita pelo PMDB também reforça o argumento da autora e será vista na seção 6 deste capítulo.
} 
mais homogênea do que era o MDB no momento de sua extinção, perdendo muito mais quadros à direita do que à esquerda.

Os dados corroboram a hipótese de Melhem (1998, p.32) segundo a qual no momento de passagem do bipartidarismo para o pluripartidarismo houve uma razoável continuidade organizacional em alguns partidos, a despeito da descontinuidade institucional no país e da alteração das regras e do espectro da competição partidária, o que se verifica através da filiação partidária dos parlamentares. O PMDB tornava-se naquele momento o principal sucedâneo dos políticos, das subunidades internas e da rede organizativa do extinto $\mathrm{MDB}^{47}$. A próxima seção deste capítulo terá como objetivo principal traçar um panorama geral desses grupos internos que formavam o MDB e que se transferem para o PMDB. A partir desse levantamento, o passo seguinte será analisar em quais campos se deram as principais perdas do PMDB.

2. As subunidades internas e a perda de quadros do MDB para os outros partidos

A presença de grupos e elementos de um amplo espectro ideológico era uma marca do MDB (Kinzo, 1988, p. 55). Ao tornarse o seu principal sucedâneo, uma parte das subunidades internas do extinto partido se transfere para o PMDB e mantém sua liberdade para se organizar internamente. As regras formais do novo partido (um fator vital para o desenvolvimento de suas atividades internas; Panebianco, 2005, pp.66-69) permitiam, desde sua fundação, a formação de tendências internas organizadas em seu interior ${ }^{48}$. O artigo $4^{\circ}$ do Estatuto do PMDB reconhece a existência e a liberdade de organização dessas diferentes

\footnotetext{
${ }^{47}$ Em muitas de suas seções estaduais o PMDB tornou-se o único herdeiro do extinto MDB, mas este não foi o caso em todos os estados naquele momento de passagem do bipartidarismo para o multipartidarismo. O processo de formação de PP e PMDB no Rio de Janeiro é exemplo disso e será mostrado no próximo Capítulo.

${ }^{48}$ Neste estudo não faremos uma diferenciação conceitual entre os termos "Tendência", "Ala", "Fração" e "Correntes" que são atribuídos às subunidades internas dos partidos políticos. Para uma revisão ampla acerca das diferentes tipologias já elaboradas para o estudo das subunidades partidárias, ver Boucek (2009)
} 
tendências, em uma parte do Capítulo 1, acerca do Partido e de seus princípios básicos:

"Art. $4^{\circ}$. São as seguintes diretrizes fundamentais para a organização e funcionamento do PMDB:

I - Democracia interna, de modo a garantir a livre escolha de seus dirigentes e eleições periódicas nos diversos níveis de sua estrutura e a participação dos filiados na orientação política do Partido, na vida partidária, garantindo o direito de formação de correntes de opinião;"49 (Estatuto do PMDB, p.1 - grifo nosso).

A partir do reconhecimento de que as regras formais permitiam a formação de "correntes de opinião" no interior do PMDB, o próximo passo a ser dado é observar empiricamente quais eram as subunidades internas do partido no momento da passagem do bipartidarismo para o pluripartidarismo. Segundo Melhem (1998, p.88) em seu estudo a respeito do MDB paulista, havia naquela organização uma disputa interna que ia além dos "Autênticos" e dos "Moderados", e esse agrupamento poderia ser feito apenas a "grosso modo".

Com isso em mente, por meio de declarações coletadas na mídia impressa e artigos produzidos por filiados ao partido, identificamos cinco grupos distintos que passaram do MDB ao PMDB: "autênticos históricos" e "Tendência Popular" à esquerda; "não-alinhados" ao centro; e "moderados e "adesistas" à direita.

"Autênticos históricos" e "Tendência Popular" são as subunidades que formam o grupo que é caracterizado pela literatura como "os autênticos". O grupo dos "autênticos históricos" era composto por políticos que não pertenciam às organizações clandestinas e que em sua maioria haviam sido eleitos em 1970 e

\footnotetext{
${ }^{49}$ Retirado do site do TSE: http://www.tse.jus.br/partidos/partidos-politicos/partido-do-movimentodemocratico-brasileiro

${ }^{50}$ Não está estre os objetivos desta pesquisa quantificar o tamanho de cada uma dessas alas em cada um dos níveis do partido. O objetivo principal desta seção será apresentar a visão dos próprios atores sobre essas subunidades e em que campo cada uma delas se localizava.
} 
1974. Esses políticos se mantiveram atuando à esquerda dentro do PMDB desde que se formou pela primeira vez o "grupo dos autênticos" no início da década de 1970, quando se abstiveram da votação no Colégio Eleitoral que teve Ulysses Guimarães como "anti-candidato" do MDB ${ }^{51}$.

Por sua vez, a "Tendência” era formada por um grupo de políticos com críticas mais radicais ao Regime e que eram mais organizados do que os "históricos". Este subgrupo havia se formado poucos meses antes da extinção do MDB e se transfere inteiro para o PMDB. A Tendência se definia como uma "corrente de opinião interna ao Partido" 52 , que procurava atuar de maneira coletiva para aproximar o partido dos movimentos sociais e das lutas populares. Os seus partidários declaravam que buscariam abrir espaço para a representação popular dentro dos órgãos de decisão do Partido, com o intuito de construir um "partido de massa" ${ }^{3}$. Devido a seu posicionamento, o grupo muitas vezes era caracterizado por políticos de outras correntes como a "esquerda radical" dentro do PMDB ${ }^{54}$. Em entrevista, o ex-Deputado Almino Affonso, coordenador nacional da Tendência, apresenta sua visão sobre o posicionamento ideológico da corrente e explica as razões do seu surgimento:

“A Tendência Popular era um grupo à esquerda dentro do PMDB, do qual eu era o Coordenador Nacional. Para quê? Para que, exatamente na hora de acabar o partido - parecia evidente que isso terminaria sendo ultimado pelo Governo -, nós tivéssemos uma alternativa. Que alternativa? Não existe

\footnotetext{
${ }^{51}$ Como exemplos de políticos "autênticos históricos" temos o Senador Pedro Simon (RS) e os Deputados Paes de Andrade (CE) e Marcos Freire (PE). Sobre a origem dos Autênticos no MDB, ver Nader (1998).

${ }^{52}$ Editorial da Folha de S. Paulo "Por que a Tendência Popular?"- 17/02/1980, escrito por um dos principais articuladores e porta-voz da Tendência (Acervo CPDOC/FGV, Verbete Almino Affonso), o exdeputado federal Almino Affonso, também ex-Ministro do Trabalho do governo João Goulart.

${ }^{53}$ Editorial da Folha de S. Paulo de 2 de março de 1980, "Um partido de massas", também escrito por Almino Affonso e Revista do PMDB, ano 1, n. 1, p. 42.

${ }^{54}$ Declaração do então Senador Itamar Franco (MG) à Folha de S. Paulo - 26/12/1979.
} 
um partido de esquerda democrático, mas precisamos ter ${ }^{\prime 5}$.

Segundo o ex-deputado aquele subgrupo era formado por 34 deputados federais e 3 senadores ${ }^{56}$, e procurava se reunir sempre de maneira prévia às reuniões oficiais do Partido, para apresentar suas reivindicações de maneira articulada. Isso teria ocorrido em pelo menos dois momentos distintos em 1980: quando o grupo realizou uma reunião prévia à abertura do Congresso, para definir suas principais pautas daquele ano ${ }^{57}$, e quando da realização da Primeira Convenção Nacional do Partido, momento no qual o grupo apresenta dois nomes para comporem a futura Executiva do Partido (o próprio Almino Affonso e o deputado federal Francisco Pinto, que viria a fazer parte da Executiva).

Parte da "Tendência Popular" era formada por militantes de outros grupos políticos organizados, que atuavam na clandestinidade e que haviam decidido trabalhar no interior do PMDB (Keck, 1991, p.114), a saber: o Partido Comunista Brasileiro (PCB), o Movimento Revolucionário 8 de outubro (MR-8 - dissidencia interna do PCB $)^{58}$ e o Partido Comunista do Brasil (PCdoB). Com relação a o PCdoB, essa “infiltração" era parte da estratégia do partido de lutar pelas liberdades políticas e, principalmente, pelo direito à livre organização (Santos, 2011, p. 10). O grupo permaneceu dentro do PMDB após o restabelecimento do pluripartidarismo devido à dificuldade imposta pela legislação

\footnotetext{
${ }^{55}$ Entrevista com o Sr. Almino AFFONSO, exibida no Programa Memória Política, da TV Câmara, em 13/11/2001. Data da Entrevista: 23/08/2007. Entrevistadoras: Ana Maria Lopes de Almeida, Iv an Santos e Tarcísio Holanda. Link para a transcrição da entrevista: http://www2.camara.leg.br/acamara/conheca/historiaoral/Memoria\%20Politica/Depoimentos/copy_of_almino-affonso/texto.html

${ }^{56}$ Alguns políticos do PMDB que declaravam compor a Tendência Popular no mês de Janeiro de 1980 são: Deputados Elquisson Soares e Francisco Pinto, ambos da BA; Deputados Airton Soares, Aurélio Peres, Otacilio Almeida e o suplente de Senador Fernando Henrique Cardoso, todos de SP; Deputado Freitas Diniz, do MA; Deputados Edgar Amorim e Tarcisio Delgado, de MG; Deputado Osvaldo Macedo, do PR; Deputado Aloísio Bezerra, do AC; Deputada Cristina Tavares e Deputado Fernando Coelho de PE; Deputado Iranildo Pereira, do CE; Deputado Adhemar Santillo, de GO. Nos primeiros meses de pluripartidarismo muitos destes políticos flertam com o processo de formação do futuro Partido dos Trabalhadores, como Airton Soares e Freitas Diniz, mas a maioria se mantem ligada ao PMDB.

${ }^{57}$ Folha de S. Paulo - 27/03/1980 - " 'Populares' já tem um programa”

${ }^{58}$ O MR-8 rompeu com o PMDB apenas em 2011, fundando um novo partido, o Partido Pátria Livre (PPL) - http://www.tse.jus.br/partidos/partidos-politicos/partido-patria-livre-ppl
} 
para se organizar um partido novo (além, é claro, do rechaço do Regime Militar). Apenas em 1985 o grupo passa a ter existência legal, quando deixa o PMDB e obtém seu registro legal pelo Tribunal Superior Eleitoral ${ }^{59}$.

Por sua vez, temos o bloco dos políticos autodenominados "não alinhados", surgido a partir do Senado, e que compreende um grupo que declara ser equidistante ideologicamente entre os "Moderados" e os "Autênticos", com um discurso mais liberal. Um de seus principais porta-vozes era o senador Itamar Franco, que criticava a Tendência por tentar dominar o partido nesse período de formação do $\mathrm{PMDB}^{60}$. O tensionamento entre estes grupos apresentava-se não apenas em nível nacional, mas também regional, impondo dificuldades para a nomeação das Comissões Provisórias Estaduais do Partido em alguns estados (como veremos na seção 6 deste capítulo).

No outro polo, mais à direita, encontravam-se os deputados do ex-MDB que eram caracterizados grosso modo como os "moderados", e que tiveram seu número reduzido antes da fundação oficial do PMDB. Como visto na primeira seção deste capítulo, houve uma migração de políticos que aderiram ao partido governista (os chamados "adesistas") e de uma forte ala de políticos moderados que passaria a compor o PP junto a Tancredo Neves. Isso fez com que o subgrupo dos "moderados" se reduzisse nos dois primeiros anos de funcionamento do partido, tendo suas fileiras reforçadas apenas quando foi homologada a incorporação do PP, em 1982, tema do próximo capítulo.

Após esta breve apresentação das subunidades internas que se transferiram do MDB para o PMDB, cabe agora analisarmos algumas das características que marcam o partido no momento de sua fundação. Nas próximas duas seções, apresento dois aspectos

\footnotetext{
${ }^{59}$ Para um histórico do PCdoB durante o Regime Militar, ver Sales (2007). Para um histórico do MR-8 ver Camurça e Reis Filho (2007).

${ }^{60}$ Entrevista publicada em Folha de S. Paulo - 27/12/1979
} 
que merecem destaque: a forte base parlamentar do PMDB no momento de seu surgimento; e a busca por vincular a imagem do “novo partido" à de seu antecessor.

3. As exigências da nova Lei dos Partidos e o caráter parlamentar do herdeiro do MDB

A nova Lei de Reforma Partidária exigia que vários passos fossem cumpridos perante o TSE para que cada partido fosse fundado oficialmente e o prazo determinado para tanto era bastante curto, de apenas um ano, com o risco de se perder tudo que fora conseguido até aquele momento caso não se tivesse cumprido as exigências. Sendo assim, foi preciso que o PMDB superasse uma série de obstáculos para se regularizar perante a Justiça Eleitoral ao mesmo tempo que articulava uma parte dos parlamentares do antigo MDB para organizarem a "nova sigla" que o sucederia ${ }^{61}$. O processo de regulamentação do PMDB perante a Justiça não foi algo simples, apesar do que poderia se pensar do principal herdeiro do MDB, ainda mais se considerarmos o fato de que alguns setores do regime militar não haviam descartado o uso de métodos intimidatórios contra a oposição (como atentados à bomba e o uso da Lei de Segurança Nacional), que continuariam a ser utilizados até o primeiro teste eleitoral do partido ${ }^{62}$.

A nova legislação instituiu que os requisitos necessários para o registro dos novos partidos seriam: uma Comissão Diretora Nacional Provisória com no mínimo 7 e no máximo 11 membros; pelo menos nove Comissões Regionais, em estados diferentes, apontadas pela Comissão Nacional Provisória; uma lista mínima

\footnotetext{
${ }^{61}$ Além de outros problemas mais específicos do PMDB, como, por exemplo, a ameaça de "despejo" de sua sede na Câmara, por conta da possível aprovação de uma nova resolução da Casa que proibiria a instalação das sedes dos novos partidos dentro de suas dependências.

${ }^{62}$ Exemplo disso foi o atentado à bomba do dia 27 de janeiro de 1980, na quadra da escola de samba Acadêmicos do Salgueiro na cidade do Rio de Janeiro, instantes antes de ser realizado um ato público com dezenas de parlamentares que participavam da articulação do partido naquele estado (Folha de $S$. Paulo - 29/01/1980). Há ainda outros exemplos de atentados ocorridos contra políticos do PMDB nesse seu primeiro ano de formação. Na noite do dia 11 de julho de 1980, por exemplo, o escritório de advocacia do Deputado Estadual paulista Flávio Bierrenbach foi alvejado por um tiro, mas ninguém se feriu.
} 
com 101 fundadores do Partido (uma questão que de partida foi motivo de debates dentro do PMDB, gerando muita discussão em torno da inclusão ou não do grupo dos “notáveis" na lista ${ }^{63}$ ); e ainda a publicação na imprensa oficial do seu manifesto de lançamento, seu estatuto e seu programa, a serem apresentados ao TSE, assim como sua aprovação em convenções municipais, regionais e nacional. Superadas essas etapas, para que o PMDB obtivesse seu registro definitivo, o partido deveria ainda obter a adesão mínima de 47 parlamentares - entre deputados e senadores ou então alcançar uma determinada porcentagem dos votos nas eleições de 1982 - 5\% do total da votação nacional, com ao menos $3 \%$ em um mínimo de nove Estados. Pelo fato de o TSE encontrarse no período de férias quando ocorreu o sancionamento da lei, o que retardaria a apresentação de instruções mais detalhadas para os futuros partidos, iniciou-se já durante o recesso de 1979 a articulação e arregimentação do máximo possível de parlamentares com vistas a garantir o cumprimento dos requisitos rumo à sua regularização.

As medidas impostas pela nova legislação partidária influenciaram o perfil fortemente parlamentar do partido em sua fundação. A nova Lei, como já dito, impunha que os partidos surgissem com uma mínima base parlamentar, a ser obtida de imediato ou nas eleições de 1982. Dessa maneira, novos partidos poderiam surgir a partir da articulação de grupos parlamentares, de imediato, ou então eleger uma bancada forte em 1982, superando as exigências mínimas. No caso do PMDB, diferentemente de outros partidos de oposição, o partido surge com uma forte base parlamentar.

\footnotetext{
${ }^{63}$ O grupo dos "notáveis" do partido compreendia todos aqueles filiados que já eram figuras expressivas da política mas que não possuíam mandato parlamentar naquele momento. Alguns deles eram apenas simpatizantes da nova legenda, mas no futuro seriam de extrema importância para o Partido. Entre este grupo, estão incluídos: Fernando Henrique Cardoso, Roberto Mangabeira Unger, Miguel Arraes de Alencar e José Serra.
} 
Comovisto nas Tabelas 5 e 6 da seção 1 deste capítulo, o PMDB possuía no momento de sua Fundação 137 parlamentares, ficando atrás apenas do partido governista em sua representação parlamentar. O partido detinha a maior bancada oposicionista das duas casas do Congresso Nacional, contando com 115 deputados e 22 senadores. Essa "gênese parlamentar" do partido acabaria por auxiliá-lo no cumprimento de outra exigência da nova legislação: a imposição de que os novos partidos surgissem nacionalizados, que impedia a formação de partidos com bases estaduais mais concentradas, como no período 1945-64 ${ }^{64}$. A articulação de um grande número de políticos em torno do PMDB visando regularizálo rapidamente facilitava a formação de novos diretórios em acordo com os requisitos mínimos da nova legislação (que exigia pelo menos nove Comissões Regionais em estados diferentes). Dessa forma, como veremos na seção 7, o PMDB pôde cumprir com os requisitos da legislação no que diz respeito à formação de diretórios mais rapidamente que os outros partidos oposicionistas.

Para medida de comparação, cabe aqui ressaltar que o partido adotava uma estratégia que o diferenciava da postura adotada por outro partido de oposição que surgia e que se colocava no campo da esquerda, mas relativamente à esquerda do PMDB, o PT. Enquanto para a formação do PT houve um forte caráter externo ao Parlamento, ligado ao papel cumprido pelos movimentos sociais ${ }^{65}$ e atrelado a uma estratégia política de cumprimento em longo prazo das exigências da nova legislação ${ }^{66}$, o PMDB tornava-se desde a sua gênese um partido com fortes bases parlamentares. Referindo-se à formação do Partido, Fernando Henrique Cardoso, um dos

\footnotetext{
${ }^{64}$ A legislação do período 1945-1964 apresentava exigências mais brandas para a formação de partidos políticos, o que acabaria por gerar partidos que se apresentavam organizados em apenas poucos estados. Sobre os partidos regionais no quadro partidário daquele período, ver Lima Jr. (1983), sobretudo Capítulo 2.

${ }^{65}$ Há uma série de estudos que demonstram o papel dos movimentos sociais no surgimento do PT. Ver, por exemplo, Keck (1991).

${ }^{66}$ Para Keck (1991, p.154), o partido buscaria cumprir os requisitos legais para a obtenção do seu registro nas eleições de 1982, fazendo uso da sua campanha eleitoral como um instrumento de organização do partido.
} 
fundadores do PMDB e suplente de senador, expressa essa perspectiva:

“O PMDB (...) não seria, talvez, o partido puro dos sonhos de muitos; nascera no berço esplêndido da oposição ao regime mais do que dos impulsos dos movimentos sociais, mas aprumava no rumo de um partido democrático de massas (...)." (citado em Melhem, 1998, p. 72).

Ao declarar que o PMDB nascera do "berço esplêndido da oposição ao Regime", essa passagem do artigo de Fernando Henrique também deixa implícita a reivindicação do PMDB quanto a ser o herdeiro da oposição institucional ao Regime Militar, papel que até então vinha sendo cumprido exclusivamente pelo MDB. Uma visão mais detalhada da reivindicação de "herdeiro do MDB", o segundo aspecto que merece destaque em sua gênese, pode ser obtida no exame, como faremos a seguir, dos primeiros documentos públicos emitidos pelo Partido.

4. Os primeiros documentos do Partido: nasce o herdeiro do MDB

No mesmo dia em que a lei de Reforma Partidária era sancionada, o PMDB tornava pública sua primeira proposta de programa partidário, a "Proposta de Debate", e também o Manifesto de Fundação do Partido. Esses dois documentos nos fornecem algumas passagens que demonstram o quanto o "novo partido" buscaria construir uma identidade vinculada a seu antecessor naquele momento de mudança do sistema partidário.

O Manifesto dos Fundadores do PMDB (conhecido pelo partido como o "Livro de Fundadores do Partido") ${ }^{67}$ foi assinado por 20 senadores, 108 deputados federais e 22 "notáveis" (figuras públicas

\footnotetext{
${ }^{67}$ No ANEXO 1 encontra-se uma reprodução do documento em sua íntegra, retirada da primeira edição da Revista do PMDB - publicada em Julho de 1981, p. 11, contendo a lista de todos os seus signatários, parlamentares e não-parlamentares.
} 
de relevo e intelectuais). Ou seja, dos 189 deputados que compunham o MDB no momento de sua extinção, são 108 os que assinam o Livro do PMDB. Como demonstramos na primeira seção deste capítulo, a maioria das defecções até aquele momento seguiu para $P P$ e $\operatorname{PDS}^{68}$.

A nova legislação partidária exigia que os partidos que surgissem, além de publicar seu Manifesto de Fundação, seriam obrigados a adotar o termo "Partido" em sua sigla. Ao refundar o MDB como PMDB, acrescentando apenas o $P$ à frente da sua "sigla mágica”, o partido adotou uma saída estratégica para manter o capital eleitoral acumulado ao longo dos anos $1970^{69}$, vinculando sua imagem à história do extinto MDB. Em seu Manifesto de Fundação, essa reivindicação da história daquele partido fica evidente em várias passagens:

"A maior truculência de todas - a dissolução coercitiva do Movimento Democrático Brasileiro - será transformada, pela mesma esperança e pela mesma fé, de um número cada vez maior de brasileiros revoltados, no maior de todos os avanços: a construção do Partido do Movimento Democrático Brasileiro."

"A constância e a inconformidade de muitos transformaram um partido indefeso numa organização vigorosa que o regime teve que extinguir para poder, por mais algum tempo, sobreviver. A constância e inconformidade transformarão o sucessor desse partido num movimento que emancipará o País não só do governo, mas do regime despótico, não só do regime, mas da ordem social vigente." (grifo nosso)

\footnotetext{
${ }^{68}$ Os outros partidos que se articulavam ainda tardariam um pouco a lançarem seus documentos oficiais. O PT, por exemplo, emitiria seu Manifesto de Fundação apenas no dia 10 de Janeiro de 1980.

${ }^{69}$ Segundo o site do PMDB (pmdb.org.br - acessado em 20/02/2014), a manutenção da sigla com a mera inclusão do "P" antes de MDB foi uma sugestão do então presidente regional do partido da cidade de Guarulhos/SP, Jorge Singh.
} 
"O Partido do Movimento Democrático Brasileiro (...) prosseguirá e intensificará a luta travada pelo Movimento Democrático Brasileiro em prol das grandes teses democráticas" (trechos retirados do Manifesto dos Fundadores do PMDB à nação ${ }^{70}$ ).

As antigas bandeiras defendidas pelo MDB também são incorporadas pelo PMDB em seu Manifesto e em seu primeiro Programa. Desde sua fundação, o partido defendeu a tese da convocação de uma nova Assembleia Nacional Constituinte (sendo o único partido a fazê-lo), uma tese histórica do MDB e que constava em seu programa para as eleições de 1978, intitulado "Constituinte com Anistia: compromissos políticos, sociais e econômicos". Lê-se no seu Manifesto:

“( O PMDB $)$ prosseguirá e intensificará a luta travada pelo Movimento Democrático Brasileiro em prol das grandes teses democráticas: manutenção do calendário eleitoral, eleições diretas em todos os níveis, defesa da autonomia dos Municípios e fortalecimento da Federação, democratização do ensino, anistia ampla, geral e irrestrita, liberdade de informação, restauração dos poderes do Congresso e convocação de uma Assembleia Nacional Constituinte." (idem)

Por sua vez, a "Proposta de Debate" do PMDB apresenta um amplo diagnóstico da conjuntura brasileira no início dos anos 1980 , apontando para uma profunda crise econômica, institucional e social ${ }^{71}$. Este primeiro esboço possui uma extensão considerável, de 24 páginas, sendo 15 delas dedicadas apenas à conjuntura econômica e social. O Partido havia apontado três intelectuais e um político com perfis bastante progressistas na época como

\footnotetext{
${ }^{70}$ Ver ANEXO 1.

${ }^{71}$ Após consulta ao arquivo do TSE, não obtivemos o documento "Proposta de debate", que não constava no arquivo do partido e que teria sido o primeiro programa elaborado pelo PMDB. Porém, as edições de 21/12/1979 do jornal Folha de S. Paulo, e de 22/12/1979 do jornal O Estado de S. Paulo, reproduzem uma série de trechos do documento, que nos serviram como base para a análise esta seção.
} 
responsáveis por elaborar o seu primeiro Programa. São eles o cientista político Roberto Mangabeira Unger, o economista José Serra, o sociólogo e suplente de Senador Fernando Henrique Cardoso e o ex-Deputado Federal Raphael de Almeida Magalhães e indicam que, caso deliberassem, poderiam incorporar recomendações de outros setores da sociedade.

A crise diagnosticada pelo partido em seu documento é atribuída à defasagem entre o sistema autoritário de poder e as aspirações da população. Nesse sentido, o partido se define como de oposição ao governo e ao Regime Militar, tal como o MDB, e propõe como solução para a superação desse quadro negativo a mobilização da população, principalmente a classe trabalhadora, para substituir através do voto as elites que comandam o Brasil de maneira autoritária. Para esse fim, a luta pelo restabelecimento de eleições diretas em todos os níveis e a convocação de uma Constituinte adquirem um caráter central para o partido alcançar seus objetivos.

Porém, apesar de procurar se aproximar do seu antecessor em suas pautas, o PMDB procura, também por meio de seu programa, apresentar uma imagem de "Partido Político" e não mais de uma frente, como fora o MDB. Lê-se:

"Como todo partido democrático, o PMDB reconhece a existência de divergências em seus quadros. Mas elas deverão convergir no sentido de uma vontade comum, definida através do debate interno e do consenso. Não sendo uma frente, mas um partido, o $P M D B$ não admitirá grupos de militantes que obedeçam a princípios e orientações de outras organizações partidárias" (Reproduzido da Folha de S. Paulo, 21/12/1979, p. 4, grifo nosso).

Em certa medida, a construção de uma imagem de "Partido Político" por parte do PMDB foi um processo que se estendeu desde sua fundação (ou de refundação do MDB) até o momento em 
que ocorre a incorporação do PP. Durante os seus dois primeiros anos de funcionamento (1980-1981), o partido procura manter sua forte base parlamentar (que, como demonstramos na primeira seção, era mais homogênea do que o MDB) e se estruturar nacionalmente visando a realização das eleições municipais de 1980 (caso elas realmente ocorressem). Durante esse período, após perder um número significativo de quadros políticos para PP e PDS, o PMDB passa a perder também alguns de seus quadros para as organizações de esquerda que surgiam. Essas novas perdas, porém, se dão em menor quantidade e são objeto de estudo das próximas duas seções.

5. A perda de quadros à esquerda

No momento em que o PMDB tornava públicos seus dois primeiros documentos oficiais, o partido também divulgou uma primeira lista de parlamentares para compor sua Comissão Nacional Provisória. Essa Comissão iria dirigir o partido até a realização de sua Convenção Nacional de Fundação, prevista para ser realizada no início de 1980 e que decidiria quais seriam os membros definitivos desta Comissão Provisória (incumbidos de dirigir o partido até que fossem cumpridas as exigências previstas na Lei de Reforma Partidária).

Prevendo a inevitabilidade da sanção presidencial da nova lei de reforma partidária, os integrantes do futuro PMDB deram início a sua articulação desde o momento em que ela fora aprovada pelo Congresso, para que, dessa forma, pudessem se adequar às novas exigências da Lei o mais rapidamente possível após a sua sanção ${ }^{72}$. Nesse ínterim, os políticos que não se sentiam contemplados em tal processo de articulação inicial passam a se afastar do processo de formação do PMDB. Nesse sentido, o futuro partido passa por

\footnotetext{
${ }^{72}$ A mensagem $n^{\circ} 103$, que encaminhou ao Congresso Nacional o PL $n^{\circ} 37$, apresentava modificações à "Lei Orgânica dos Partidos Políticos", sancionada em 1971 e a outros dispositivos legais, sendo lida em plenário no dia 19 de outubro de 1979 (Delgado, 2006). A votação da Reforma Partidária se deu em tumultuadas sessões no Congresso nos dias 21 e 22 de novembro de 1979 e sua aprovação se deu sob muitos protestos de algumas alas do antigo MDB.
} 
novas defecções em seus quadros, dessa vez à esquerda, no período entre a divulgação de seus primeiros documentos e a realização de sua Primeira Convenção Nacional (20 de dezembro de 1979 e 16 de janeiro de 1980).

Parte dos Deputados identificados com a Tendência Popular passaram a se aproximar gradativamente de um grupo denominado "Forças da Base", que, então, contribuía para a formação do PT (Keck, 1991, p.112-113), devido a certa afinidade ideológica. Essa aproximação entre os dois grupos foi estudada por Keck sob a ótica da estratégia adotada pelo Partido dos Trabalhadores em sua formação:

"Lula e outros líderes do PT tiveram encontros frequentes com os membros da Tendência Popular na Assembleia Legislativa de São Paulo, à medida que os que já haviam se filiado ao novo partido tentavam recrutar outros". (Keck, 1991, p. 100).

Ainda segundo a autora (idem, p. 90), sete deputados estaduais de São Paulo deixaram essa ala e passaram a contribuir para a construção do PT no início de 1980. Um depoimento dado pelo expresidente Lula também confirma esse processo de aproximação:

"Convidamos (para as reuniões iniciais do PT) um pessoal da chamada 'área popular' do MDB, os 'autênticos' do partido. (...) Das reuniões participaram o Chico Pinto (Francisco Pinto), o Fernando Lyra, o Alceu Collares, pessoas que também tinham a ideia de criar outro partido, como o Fernando Henrique."

"Mas a ideia de criar um novo partido com esse pessoal todo não evoluiu, porque, na verdade, não queriam criar um novo partido político, pretendiam constituir algo do tipo do MDB Autêntico, o que a gente 
achava que era pouco" (grifo nosso, Melhem e Russo, 2004, pp. 239-240).

Nos dias 15 e 16 de janeiro de 1980, em Brasília, foi realizada a Convenção Nacional dos Fundadores do PMDB, e naquele momento evidenciaram-se as perdas à esquerda do partido. Antes de apontarmos quais foram os políticos que saíram do PMDB, cabe aqui um pequeno parêntese histórico sobre as decisões dessa Convenção.

No primeiro dia, os seus políticos discutiram o Programa, o Estatuto e o Manifesto do partido, sendo este último aprovado em caráter definitivo. Em seguida, foi eleita a "Comissão Provisória definitiva" do partido, que iria comandá-lo até que sua regularização junto ao TSE estivesse completa. Todos os escolhidos para compor o órgão eram parlamentares naquele momento: os senadores Orestes Quércia (SP), Franco Montoro (SP), Teotônio Vilela (AL), Itamar Franco (MG) e Mauro Benevides (CE), e os deputados Ulysses Guimarães (SP), Freitas Nobre (SP), Paulo Rates (RJ), Aldo Fagundes (RS), Francisco Pinto (BA) e Fernando Coelho (PE). Dos 11 indicados, 6 eram do Sudeste (4 paulistas, 1 mineiro e 1 carioca), 1 era do Sul (um gaúcho) e mais 4 eram nordestinos (1 alagoano, 1 cearense, 1 baiano e 1 pernambucano).

No segundo dia da Convenção foram escolhidas pela Comissão Nacional as Comissões Provisórias regionais e aprovados os textos do Programa e do Estatuto do Partido, que ainda deveriam posteriormente ser aprovados em outras instâncias do PMDB (suas futuras Convenções Regionais e Municipais). Naquele momento, inicia-se uma série de disputas regionais entre as diferentes tendências a fim de acomodá-las nos órgãos de direção do partido. Como consequência, o partido teria que lidar com mais defecções em seus quadros, sobretudo à esquerda, o que também caracterizava 
um obstáculo para que o partido se adequasse à nova legislação partidária e formasse os seus Diretórios ${ }^{73}$.

A disputa pelo controle das Comissões Provisórias Estaduais era central para o controle da máquina partidária naquele momento. As elites locais buscavam construir seu espaço na nova sigla visando a possível realização das eleições de 1980 (ou pelo menos as eleições previstas para 1982). Garantindo o controle das Comissões Provisórias, os políticos poderiam ocupar um maior espaço quando as Comissões se tornassem permanentes, e ganhariam a atribuição de indicar as listas de candidatos para as eleições proporcionais e os convencionais que decidiriam os futuros candidatos a cargos majoritários ${ }^{74}$.

Durante a realização da Convenção alguns dos políticos da Tendência Popular que não se sentiam contemplados com as escolhas para as Comissões Provisórias anunciaram o seu desligamento do partido, migrando para o PT ou para o PTB Brizolista ${ }^{75}$. Foi o caso do Deputado Airton Soares (SP), vice-líder da bancada do ex-MDB, que anunciou sua desfiliação do PMDB e seu ingresso no PT, seguindo o mesmo caminho que os Deputados Edson Khair (RJ) e Antônio Carlos (MS). No dia seguinte à Convenção (17 de janeiro) os irmãos Senador Henrique Santillo e o Deputado Adhemar Santillo (ambos de GO) também anunciaram seu

\footnotetext{
${ }^{73}$ Surgem tensões em muitos estados, como Amazonas, Acre, Sergipe, Santa Catarina, São Paulo e Goiás, que atrasam a formação de suas Comissões Regionais. No PMDB de São Paulo, por exemplo, Aurélio Peres, militante comunista que atuava no MDB e fazia parte da Tendência Popular reivindica uma vaga na Comissão Provisória daquele estado.

${ }^{74}$ A disputa pelo PMDB de Amazonas chegou a ser inclusive física entre os dois grupos que reivindicavam para si a Comissão Provisória, com ambos indo a Brasília para pressionar a direção nacional para que tomassem uma decisão. Um grupo formado pelo ex-senador Arthur Virgílio, seu filho Arthur Virgilio Neto e o senador Evandro Carreira e outro grupo, formado pelo vereador de Manaus Fábio Lucena e pelo deputado Mário Frota trocaram inúmeros insultos e quase chegaram às vias de fato. Em declaração reproduzida na Folha de S. Paulo (mas não confirmada pelo político) Arthur Virgilio exclama: "ou você (Ulysses Guimarães) entrega esse partido para o meu grupo ou vou destruir o MDB!" - Folha de S. Paulo, 05/02/1980 - "No gabinete de Ulysses, só insultos".

${ }^{75}$ Este processo de perda de quadros à esquerda do PMDB pode ser caracterizado como a "primeira onda" de saída de políticos progressistas do partido. Uma hipótese passível de verificação futura mas que excede o recorte histórico desta pesquisa seria verificar o quanto a Fundação de PCB e PCdoB em 1985 e PSDB em 1988 representaram outras "ondas de saída" de políticos progressistas do PMDB.
} 
desligamento do PMDB e seu ingresso no $\mathrm{PT}^{76}$. O argumento de ambos era que a Comissão Nacional optou por uma ala mais conservadora na escolha das lideranças de Goiás, e que não estavam dando espaço a membros não-parlamentares, ligados aos movimentos sociais e à Tendência. Segundo eles, o PMDB estava se tornando um partido apenas de parlamentares ${ }^{77}$.

No dia 18 de janeiro, após a Convenção, reuniu-se pela primeira vez a Comissão Nacional Provisória do PMDB, que define os seus primeiros cargos: Ulysses Guimarães (Deputado Federal-SP) como presidente, Aldo Fagundes (Deputado Federal-RS) como secretário geral do partido (cargo que no antigo MDB era ocupado por Thales Ramalho, que passa a construir o PP e acaba se afastando do PMDB) e Mauro Benevides para a tesouraria. Alguns dias depois, definem-se outros cargos: dois vice-presidentes, Teotônio Vilela (que havia passado à oposição poucos meses antes) e Fernando Coelho (da "Tendência Popular"), assim como cinco políticos designados para representar o partido junto ao TSE, os deputados José Costa, Antônio Russo e Israel Dias Novais, o senador Humberto Lucena e o advogado Osmar Melo. A representação junto ao TSE foi ampliada em comparação com o MDB com o intuito de acelerar o processo de regulamentação do partido tão logo o TSE baixasse suas normas. Iniciam-se, a partir de então, todos os trâmites para a obtenção do registro definitivo do PMDB, que serão apresentados na próxima seção.

\section{A obtenção do registro definitivo}

No dia 8 de fevereiro de 1980 o PMDB ingressava oficialmente com sua documentação junto ao TSE para obtenção do Registro Provisório, sendo o primeiro partido a fazê-lo, antes mesmo do

\footnotetext{
${ }^{76}$ O Deputado Santillo se afastou do PMDB e esteve filiado ao PT durante oito meses no ano de 1980, mas após este período acabou por retornar ao PMDB (retirado do Dicionário Histórico Biográfico brasileiro, publicado pelo Centro de Pesquisa e Documentação de História Contemporânea do Brasil da Fundação Getúlio Vargas, no volume IV, páginas 3079 e 3080). Seu irmão, o Senador Henrique Santillo também pertenceu ao PT durante alguns meses, retornando ao PMDB em 1 de Agosto de 1980.

${ }^{77}$ Folha de S. Paulo, 18 de janeiro de 1980 - reportagem com o sugestivo título de "O crescimento das deserções preocupa o PMDB".
} 
futuro partido governista ${ }^{78}$. Porém, no dia 15 do mesmo mês, o TSE publica a resolução 10.785, regulamentando a Lei Orgânica dos partidos políticos, com 178 artigos a serem cumpridos, e sinaliza que o primeiro pedido de registro provisório do PMDB será arquivado pelo Tribunal, sob a alegação de falta de documentos ${ }^{79}$.

Um mês depois desses acontecimentos, no dia 10 de abril de 1980, o Partido apresenta à Justiça Eleitoral sua nova documentação ${ }^{80}$. Os representantes do Partido informam também que houve mais defecções em seus quadros após o Congresso de Fundação de janeiro do mesmo ano. Por conta das perdas causadas por políticos que se transferiram para PT e PDT, no momento do novo registro constavam 18 senadores e 88 deputados filiados ao PMDB.

Por fim, no dia 6 de maio de 1980, o partido teve deferido pelo TSE o seu pedido de registro partidário provisório, tornando-se o primeiro partido a obtê-lo dentro das novas regras em vigor. Dessa forma, mostrou ter superado as vicissitudes da nomeação de suas Comissões Provisórias e as perdas de políticos do MDB que se transferiram para os outros partidos em formação. A partir daquela data, o Partido teria um ano para organizar-se nacionalmente e, cumprindo com todos os requisitos necessários, obteria finalmente o seu registro definitivo, atuando, assim, dentro da legalidade.

Tendo sido o primeiro partido a alcançar essa etapa, o PMDB passa a dividir seus esforços entre a arregimentação de novos quadros e a construção de uma estrutura organizativa nacional. Tais medidas eram de grande interesse do partido, pois, além de condicionar a obtenção de seu registro definitivo, criavam condições suficientes para a realização das eleições de 1980 .

\footnotetext{
${ }^{78}$ Pedido de Registro de Partido ${ }^{\circ} 27$ - TSE

79 O mesmo acabou por ocorrer com o PTB de Brizola e o PTB de Ivete Vargas, que ainda reivindicavam a sigla durante o ano de 1980. A disputa de Ivete Vargas e Leonel Brizola pelo novo PTB se estende durante muitos meses. Até o início de 1981 o grupo Brizolista ainda tenta cassar o registro da sigla obtido pelo grupo Varguista.

${ }^{80}$ Pedido de Registro de Partido - RGP n ${ }^{\circ} 31$ - Resolução/TSE no 10.841
} 
Para fazer um balanço de sua organização nacional, o PMDB realizou nos dias 16 e 17 de setembro daquele ano uma "Mini Convenção Nacional”, na qual a avaliação interna é bastante positiva: até aquela data o partido contava com 2.300 Comissões Provisórias devendo constituir Diretórios definitivos em pelo menos 1.800 municípios (de um total de 3954 municípios brasileiros naquele momento). Os próximos passos dados pelo partido seriam a realização de suas Convenções Municipais, Regionais e por fim a sua Convenção Nacional.

As Convenções Municipais do partido realizaram-se em 12 de outubro de 1980. Naquela ocasião, seus líderes destacam que o novo partido havia alcançado em alguns Estados um número maior de diretórios do que possuía o MDB no momento de sua extinção ${ }^{81}$. Com base no número de Diretórios eleitos, nota-se que desde sua fundação o PMDB possuía fortes bases municipais. O partido elegeu diretórios em ao menos 2.066 municípios, ficando acima do exigido pela legislação (20\%) em pelo menos 23 Estados e Territórios.

Tabela 7. Diretórios Municipais eleitos em 12/10/1980*

\begin{tabular}{lcc}
\hline \hline & Municípios & Diretórios \\
\hline \hline Acre & 12 & $12(100 \%)$ \\
\hline Alagoas & 94 & $47(50 \%)$ \\
\hline Território do Amapá & 5 & $2(40 \%)$ \\
\hline Bahia & 102 & $62(61 \%)$ \\
\hline Ceará & 140 & $77(55 \%)$ \\
\hline Espírito Santo & 55 & $52(94 \%)$ \\
\hline Goiás & 223 & $211(95 \%)$ \\
\hline Mato Grosso do Sul & 64 & $51(80 \%)$ \\
\hline Minas Gerais & 722 & $146(20 \%)$ \\
\hline Maranhão & 131 & $33(25 \%)$ \\
\hline Paraíba & 171 & $80(47 \%)$ \\
\hline Paraná & 295 & $250(85 \%)$ \\
\hline Pernambuco & 83 & $43(52 \%)$ \\
\hline Piauí & 184 & $101(55 \%)$ \\
\hline \hline
\end{tabular}

\footnotetext{
${ }^{81}$ Segundo Ulysses Guimarães, em 10 Estados foram constituídos mais diretórios do que possuía o MDB - Folha de S. Paulo, 14/10/1980, p. 4.
} 


\begin{tabular}{lcc}
\hline \hline Rio Grande do Sul & 282 & $200(71 \%)$ \\
\hline Rio Grande do Norte & 150 & $30(20 \%)$ \\
\hline Rio de Janeiro & 64 & $33(51 \%)$ \\
\hline Território de Roraima & 2 & $2(100 \%)$ \\
\hline Território de Rondônia & 7 & $6(86 \%)$ \\
\hline Santa Catarina & 197 & $150(76 \%)$ \\
\hline São Paulo & 571 & $400(70 \%)^{* *}$ \\
\hline Sergipe & 74 & $37(50 \%)$ \\
\hline Total & $\mathbf{3 7 4 2}$ & $\mathbf{2 0 6 6}$ \\
\hline \hline
\end{tabular}

* A tabela não apresenta dados para os Estados de MT e AM, que não foram divulgados pela imprensa no período.

**Não confirmada pelo TSE.

Fonte: Dados do TSE cedidos a Folha de S. Paulo - 14/10/1980, p.4

Em 23 de novembro de 1980, realizam-se as Convenções Estaduais para as eleições dos Diretórios Regionais do Partido. Na maioria dos Estados não houve disputas e a escolha se deu através da homologação de chapa única. Por sua vez, cada Diretório Regional elege suas respectivas Comissões Executivas, nomeia seus prováveis candidatos às eleições de 1982, assim como os delegados do PMDB de cada Estado para se dirigirem à Convenção Nacional do Partido.

Finalmente, nos dias 6 e 7 de dezembro, foi realizada a Primeira Convenção Nacional do PMDB, no plenário da Câmara dos Deputados ${ }^{82}$. No primeiro dia, o partido aprova seu Estatuto, Código de Ética e Programa Partidário, deixando como indicativo para o ano de 1981 uma avaliação das emendas e sugestões propostas pelas suas bases municipais ${ }^{83}$. No segundo dia da Convenção elegem-se e tomam posse os 69 membros do Diretório Nacional e os 13 componentes da Comissão Executiva Nacional ${ }^{84}$, que dirigiriam o partido a partir de então. A Comissão eleita para um mandato de um ano era formada por 12 ex-emedebistas e apenas um ex-arenista (o senador Teotônio Vilela), e tem os seus cargos distribuídos da seguinte maneira:

\footnotetext{
${ }^{82}$ O único partido a realizar sua Convenção Nacional antes do PMDB é o PDS, em 29 e 30 de novembro de 1980 .

${ }^{83}$ Caso fosse aprovada qualquer alteração, os documentos teriam que ser mais uma vez aprovados por Convenções Municipais e Regionais do Partido, retardando a obtenção do seu Registro Definitivo.

${ }^{84}$ A composição deste primeiro Diretório Nacional do PMDB encontra-se no ANEXO 2
} 
Presidente: Ulysses Guimarães

$1^{\circ}$ Vice-presidente: Teotônio Vilela

$2^{\circ}$ Vice-presidente: Miguel Arraes

$3^{\circ}$ Vice-presidente: Alencar Furtado

Secretário-geral: Pedro Simon

$1^{\circ}$ Secretário: Paulo Rattes

$2^{\circ}$ Secretário: Euclides Scalco

Tesoureiro Geral: Mauro Benevides

1 Tesoureiro: Tarcísio Delgado

Vogais: Franco Montoro, Orestes Quércia, Francisco Pinto e Fernando Cunha

A composição da primeira Executiva Nacional do PMDB é outro aspecto que evidencia a maior homogeneidade do partido em relação ao seu antecessor, o MDB. Enquanto a última Comissão Executiva Nacional do extinto partido possuía entre seus membros quatro autênticos (Alencar Furtado, Jarbas Vasconcellos, Marcondes Gadelha e João Gilberto) e cinco moderados (Tancredo Neves, Thales Ramalho, Mauro Benevides, Valter Guimarães e Lázaro Barbosa) ${ }^{85}$, alguns dos quais se filiaram ao PP na passagem para o pluripartidarismo, a composição da primeira Executiva Nacional do PMDB inclui sete autênticos (Miguel Arraes, Alencar Furtado, Pedro Simon, Euclides Scalco, Tarcísio Delgado, Francisco Pinto e Fernando Cunha) e apenas um moderado (Mauro Benevides) ${ }^{86}$. Cabe destacar que o importante cargo de Secretário Geral, que no MDB era exercido por um moderado (Thales Ramalho), no PMDB passaria a ser exercido por um "autêntico histórico"(Pedro Simon).

Após a realização de suas Convenções Municipais, Regionais e Nacional, o último passo a ser dado pelo PMDB para a sua completa legalização seria o ingresso com seu pedido de registro

\footnotetext{
${ }^{85}$ Folha de S. Paulo-05/11/1979, p. 4

${ }^{86}$ Os outros políticos ou se aproximam do grupo dos não-alinhados, tal como Teotônio Vilella e Paulo Rattes, ou orbitam entre os grupos, como o Presidente do partido Ulysses Guimarães.
} 
definitivo junto ao TSE, o que ocorreu no dia 30 de abril de 1981. Dois meses depois, no dia 30 de junho, o registro definitivo foi concedido (Pedido de Registro Definitivo - RGP $\mathrm{n}^{\mathbf{0}} 38$ Resolução/TSE $\left.n^{\circ} 11.042\right)^{87}$. O PMDB tornava-se, naquele momento, o segundo partido a obter seu registro definitivo desde o restabelecimento do pluripartidarismo, sucedendo apenas ao PDS.

7. A reabertura da Câmara e o princípio da atuação parlamentar da bancada peemedebista

Nesta última seção, apresentamos alguns aspectos da atuação parlamentar do PMDB em seu primeiro ano de atuação. O objetivo é demonstrar a identidade de oposição ao governo e ao Regime que o partido procura construir perante a opinião pública por meio de algumas de suas propostas e do seu posicionamento em algumas matérias votadas naquele ano.

O descompasso entre a nova legislação partidária e o início dos trabalhos parlamentares no ano de 1980 gerou um resultado um tanto quanto esdrúxulo: a Câmara Federal reabriu em $1^{\circ}$ de março de 1980, pela primeira vez em sua história, "sem partidos". O Congresso possuía apenas "blocos parlamentares", com vários deputados sem vínculo a nenhum partido político, aguardando que eles obtivessem seu registro definitivo a fim de optar a qual sigla iriam se filiar. Freitas Nobre (SP) foi escolhido como o primeiro líder do bloco partidário do PMDB na Câmara, enquanto que Paulo Brossard (RS) foi escolhido para exercer o cargo no Senado. No momento da formalização do "bloco" peemedebista o partido contava com apenas 17 senadores e 83 deputados, o que ficava abaixo das expectativas iniciais, anteriores à reabertura do

\footnotetext{
${ }^{87}$ A lei estabelecia que os partidos teriam o prazo de 1 ano após o seu registro provisório para pedir o registro definitivo, o que no caso do PMDB deveria ocorrer até o dia 6 de maio de 1981. Porém, os novos dirigentes do PMDB optam por adiar a decisão e aguardar pela tramitação de um projeto elaborado pelo senador Franco Montoro que alteraria o prazo de filiação de futuros candidatos a cargos eletivos (reduzindo de 2 para 1 ano o prazo de nova filiação partidária para que haja possibilidade de se candidatar a um cargo). Adiando a sua decisão, os dirigentes concluíram que novas adesões poderiam chegar ao partido neste momento de grande flutuação de seus quadros, com prováveis futuros candidatos ingressando no PMDB para as eleições de 1982.
} 
Congresso, e era resultado, principalmente, das perdas no campo "moderado/adesista" do antigo MDB.

Durante o primeiro mês de sessões parlamentares, a "Tendência Popular", corrente interna que representava parte da esquerda do PMDB, reúne-se para definir qual seria sua linha de atuação naquele primeiro ano de existência do partido. A corrente procurava agir como "bancada", propondo temas e demarcando posição dentro do partido ao longo de todo o ano de 1980, o que contribuiu para que o partido ocupasse um espaço à esquerda de outras organizações partidárias que surgiam, tal como PP e PDS. Elencaram-se como objetivos políticos da Tendência: lutar para que o partido cumprisse seu compromisso em se tornar uma legenda mais popular que o MDB; intensificar a campanha pela convocação de uma Assembleia Nacional Constituinte, e ainda reivindicações de cunho econômico-social, como lutar pela destinação constitucional de $12 \%$ do PIB para a educação ${ }^{88}$.

Com a reabertura dos trabalhos, a futura bancada peemedebista procura, ao longo do ano de 1980, focar seus esforços no Parlamento em uma série de medidas institucionais rumo à redemocratização. Várias emendas importantes de caráter políticoinstitucional seriam apresentadas e apreciadas pela bancada do PMDB em 1980, como parte do processo de abertura política. Uma das principais medidas de curto prazo, do ponto de vista da oposição, seria garantir que fossem realizadas as eleições municipais em novembro daquele ano, apesar de toda insegurança organizativa que marca os partidos em seu primeiro ano de formação. Uma das soluções propostas foi o projeto apresentado pelo deputado Humberto Lucena (PMDB/PB), que atribuía às Comissões Provisórias Municipais dos partidos políticos em organização a escolha dos candidatos às eleições de 1980 (uma interessante saída política para criar condições para a realização

\footnotetext{
${ }^{88}$ Folha de S. Paulo, 27/03/1980, p.4
} 
daquele pleito). A ideia de fundo era de que a realização desse pleito seria um primeiro passo a ser dado para garantir futuras eleições diretas para outras esferas de poder, como, por exemplo, para os cargos de Governadores dos Estados ${ }^{89}$. Nesse sentido temos também a subemenda proposta pelo Deputado Ralph Biasi (PMDB/SP), que visava garantir a realização de eleições diretas para governador em 1982, pedindo também por diretas para presidente em 1986 e pelo fim do mandato dos biônicos em 1982.

O debate em torno das eleições municipais de 1980 acaba se materializando numa das mais tumultuadas sessões do Congresso daquele ano. Na madrugada de 4 para 5 setembro, em meio a discussões e agressões físicas, aprovou-se a Emenda Constitucional apresentada pelo Deputado Anísio Teixeira, que prorroga o mandato dos prefeitos e vereadores em exercício por mais dois $\operatorname{anos}^{90}$. Assim, foram adiadas para 1982 as eleições municipais previstas para 1980, causando uma futura concomitância de eleições estaduais e municipais. Na Câmara a medida foi aprovada com 218 votos, sendo 217 do PDS e um do PMDB - dado pelo deputado goiano Iturival Nascimento, que logo em seguida entra em conflito interno com o Partido e chega a se desligar do PMDB durante alguns meses ${ }^{91}$ - e no Senado com 36 votos (35 governistas e um "biônico" sem partido até aquele momento). A aprovação da emenda representa uma grande derrota para a bancada federal do PMDB, que havia se retirado do plenário na primeira sessão de votação após o presidente do Senado ter mantido vetos ao processo de obstrução que lhe foi pedido e era previsto no regimento parlamentar. A aprovação também faz com que surja nos partidos de oposição um temor de que as eleições de 1982 também acabassem por ser adiadas, mantendo aquela configuração do

\footnotetext{
${ }^{89}$ Quanto ao tema das eleições de 1980, cabe apontar que o TSE cumpriu seu papel protocolar ao fixar a data das eleições para 15 de novembro, determinando também os prazos para o alistamento eleitoral (6 de agosto) e para a escolha de candidatos pelos partidos (6 de setembro).

${ }_{90}$ O Projeto tornou-se a Emenda Constitucional n. 14, de 9 de setembro de 1980, alterando a redação do art. 209 da Constituição, nela introduzida pela Emenda n. 8, de 14 de abril de 1977 (o chamado "Pacote de Abril").

${ }^{91}$ Retirado do verbete "Iturival Nascimento" do Acervo CPDOV/FGV;
} 
Colégio Eleitoral para a escolha do sucessor do Presidente Figueiredo.

Mas não foram apenas disputas (às vezes físicas) que o PMDB teve que enfrentar em seu primeiro ano de atuação parlamentar. Durante todo o ano de 1980 há um grande constrangimento da bancada oposicionista por parte do governo. Além de ter alguns de seus discursos censurados pela mesa da Câmara (como o proferido em 19 de junho pelo Deputado Aurélio Peres, membro da Tendência Popular), a Lei de Segurança Nacional era utilizada sempre que o regime julgava necessário e os discursos parlamentares mais enérgicos acabavam por ser enquadrados na Lei. Como exemplos, o discurso do Deputado João Cunha (temporariamente filiado ao $\mathrm{PT} / \mathrm{SP}$, mas que posteriormente retornaria ao PMDB, em 1981) proferido na Câmara em 28 de abril é enquadrado no artigo $33 \mathrm{da}$ Lei, por ofensas à honra do presidente e dos oficiais-generais (sendo posteriormente inocentado no STF) e o discurso do deputado Francisco Pinto (PMDB/BA, da Tendência Popular), que também sofre ameaças de enquadramento na Lei por ter dado apoio a João Cunha (em denúncia feita pelo então chefe do SNI, o general Otávio Medeiros, também por “delito contra a segurança nacional").

O segundo tema referente a medidas político-institucionais de abertura política que gera forte repercussão na Câmara em 1980 é o restabelecimento das prerrogativas do Poder Legislativo, perdidas em 1969 com a Emenda Constitucional $n^{\circ} 1^{92}$. A emenda para reverter esse quadro fora apresentada por três deputados governistas: Flávio Marcilio, Djalma Marinho e Célio Borja, mas não recebe o apoio de toda a bancada de sustentação do governo e nem mesmo de toda a oposição. Em um primeiro momento, esperava-se que a bancada do PDS negaria o quórum necessário para que a Emenda fosse votada, mas na sessão parlamentar de 15

\footnotetext{
${ }^{92}$ Sobre a Emenda, ver Araújo e Maciel (2002).
} 
de outubro de 1980, dia da votação da Emenda, 218 deputados estavam presentes na sessão (três a mais do que o necessário), e a votação ocorre. Seriam necessários 211 votos para que a Emenda fosse aprovada na Câmara, mas nem mesmo contando com dissidentes governistas (16 Deputados do PDS se posicionaram a favor de sua aprovação) a matéria pôde ser aprovada, tendo chegado a apenas 196 votos favoráveis a sua aprovação. Seis deputados do PMDB estavam ausentes no momento da votação, mas, mesmo com a sua presença, a medida não seria aprovada. O resultado final é bastante decepcionante para os partidos de oposição mas, por outro lado, deixa uma perspectiva otimista para o futuro, ao tornar público o fato de que já havia, em 1980, certa dissidência interna no partido governista.

O último grande tema em debate no âmbito do Poder Legislativo e que mobiliza toda a bancada do PMDB é a possibilidade de restabelecimento de eleições diretas para os cargos de Governadores dos Estados em 1982. Considerando-se que no ano de 1980 não seriam mais realizadas as eleições municipais anteriormente previstas, o PMDB concentra seus esforços para que se criem condições para a realização das eleições de 1982, que colocariam em disputa os cargos municipais e estaduais.

A Presidência da República enviara ao Congresso, ainda em 1979, uma proposta de Emenda Constitucional que restabelecia as eleições diretas para governador em 1982, assim como extinguia os senadores eleitos indiretamente, os chamados "biônicos", mantendo os seus mandatos até o fim. O relator da proposta e autor do substitutivo, que não a alterava em sua essência, foi o Deputado Edson Lobão, vice-líder do governo, deputado pelo PDS do Maranhão. A bancada do PMDB na Câmara insiste durante toda a tramitação em pedir destaque à sua proposta de subemenda, que estende as eleições diretas também para o cargo de Presidência da República. Seu intuito era o de demarcar a posição do partido em torno de um tema que só viria a ter respaldo popular mais de três 
anos depois, com o movimento das “Diretas-Já". Ao final dos debates, por meio de um acordo entre o partido da situação e os de oposição, o substitutivo oposicionista foi declarado "prejudicado", de maneira que o plenário optou por dar preferência à proposta governamental e não prejudicar a votação da emenda.

A matéria por fim é aprovada no Congresso Nacional em 13 de novembro por unanimidade dos presentes nas duas Casas. A votação teve apoio maciço do PMDB (com apenas cinco filiados ausentes) e do PP (com quatro ausentes) ${ }^{93}$. No dia 19 de novembro, em cerimônia solene no Palácio do Planalto, a Emenda Constitucional $\mathrm{n}^{\circ} 15$ é promulgada pelo Presidente Figueiredo e inicia-se assim um novo processo no PMDB: a articulação de candidaturas para o pleito de 1982, quando pela primeira vez desde 1965 seriam escolhidos por via direta os governadores dos Estados ${ }^{94}$.

\section{Considerações finais}

Em seu primeiro ano de funcionamento desde o restabelecimento do pluripartidarismo, o PMDB teve que dividir seus esforços em uma série de frentes: adequar-se à nova legislação partidária, formar uma base parlamentar mínima, elaborar seus primeiros documentos, realizar convenções em todos os níveis da Federação e ainda construir uma rede organizativa nacional. O cumprimento da legislação imposta pelo TSE não se deu de maneira tão fácil quanto se esperaria de um partido considerado pela literatura como "herdeiro direto" do antigo MDB, e o seu processo de regulamentação dura quase um ano. Além de estruturar-se nacionalmente e construir uma identidade própria, houve uma grande flutuação dos quadros dos partidos que se formavam e parte

\footnotetext{
93 A matéria também extinguiu os chamados "Senadores biônicos", apesar de ter mantido o mandato daqueles que estavam em exercício.

${ }^{94}$ No ano de 1965, 11 Estados elegeram seus governadores: Alagoas, Goiás, Guanabara, Maranhão, Mato Grosso, Minas Gerais, Pará, Paraíba, Paraná, Rio Grande do Norte e Santa Catarina.
} 
dos políticos que eram filiados ao extinto MDB se dispersa ao longo do novo cenário pluripartidário.

Conforme descrito ao longo deste capítulo, uma ala significativa de políticos localizados no campo moderado do antigo MDB não segue para o PMDB, transferindo-se para outras agremiações em formação, como o PP e o PDS. Houve também defecções à esquerda do partido, rumo ao PT ou o PTB Brizolista (posterior PDT), mas elas foram minoritárias e o partido logrou manter em seu interior uma ala de esquerda, representada pela "Tendência Popular” e pelos "autênticos históricos" como herança do antigo MDB. Esse processo teve como resultado um PMDB mais homogêneo do que fora o MDB no momento de sua extinção, o que levou Kinzo (1988, p. 210) a concluir que o novo partido surgia com uma composição mais de centro-esquerda do que o seu antecessor.

Porém, no ano de 1981, um evento político teria consequências importantes para a composição interna do partido, alterando a sua formação mais homogênea: a incorporação do Partido Popular ao PMDB, que traria de volta para o partido os componentes da sua ala moderada, reforçada por uma ala de políticos egressos da Arena, e será o tema de estudo do próximo capítulo. 


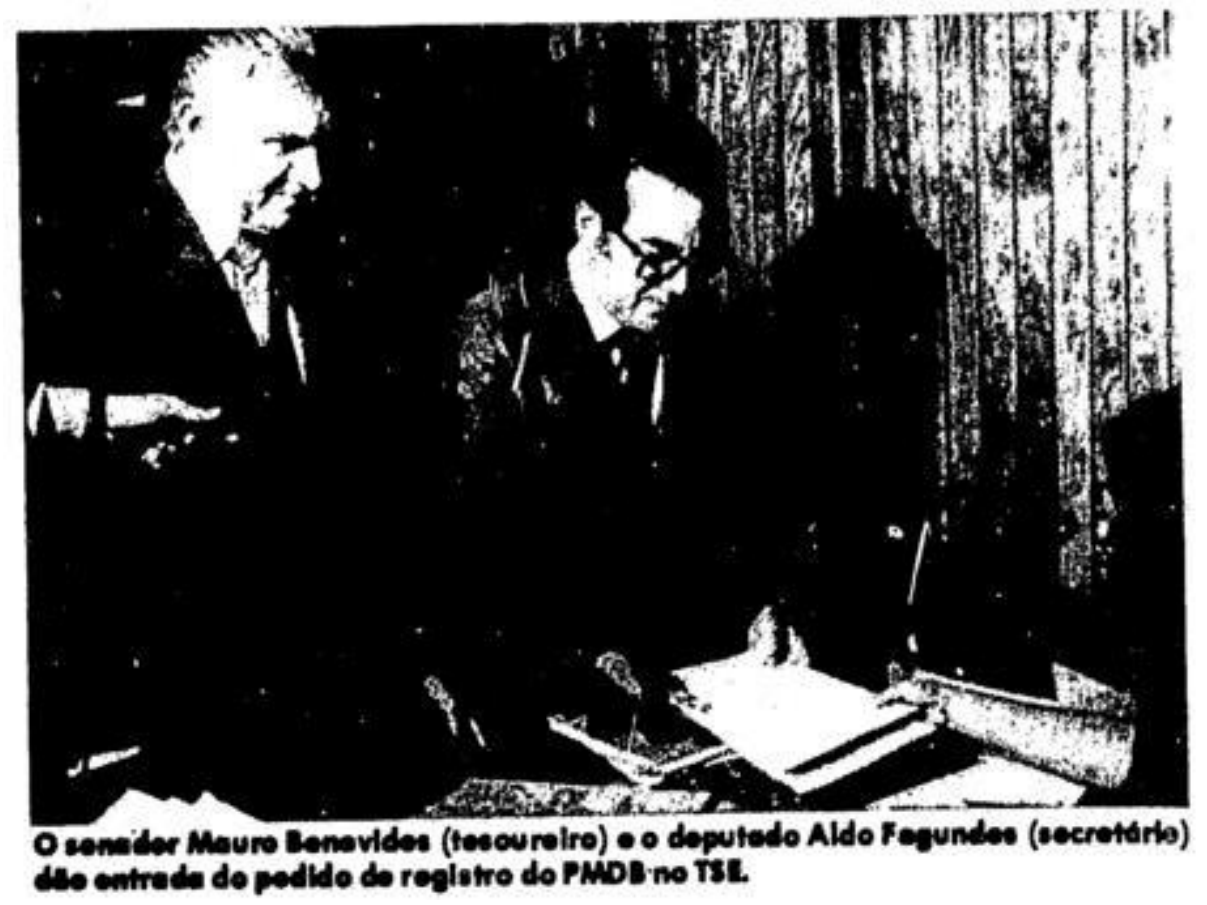

Dirigentes do PMDB dão entrada no pedido de registro provisório do partido. Folha de S. Paulo, 9 de fevereiro de 1980

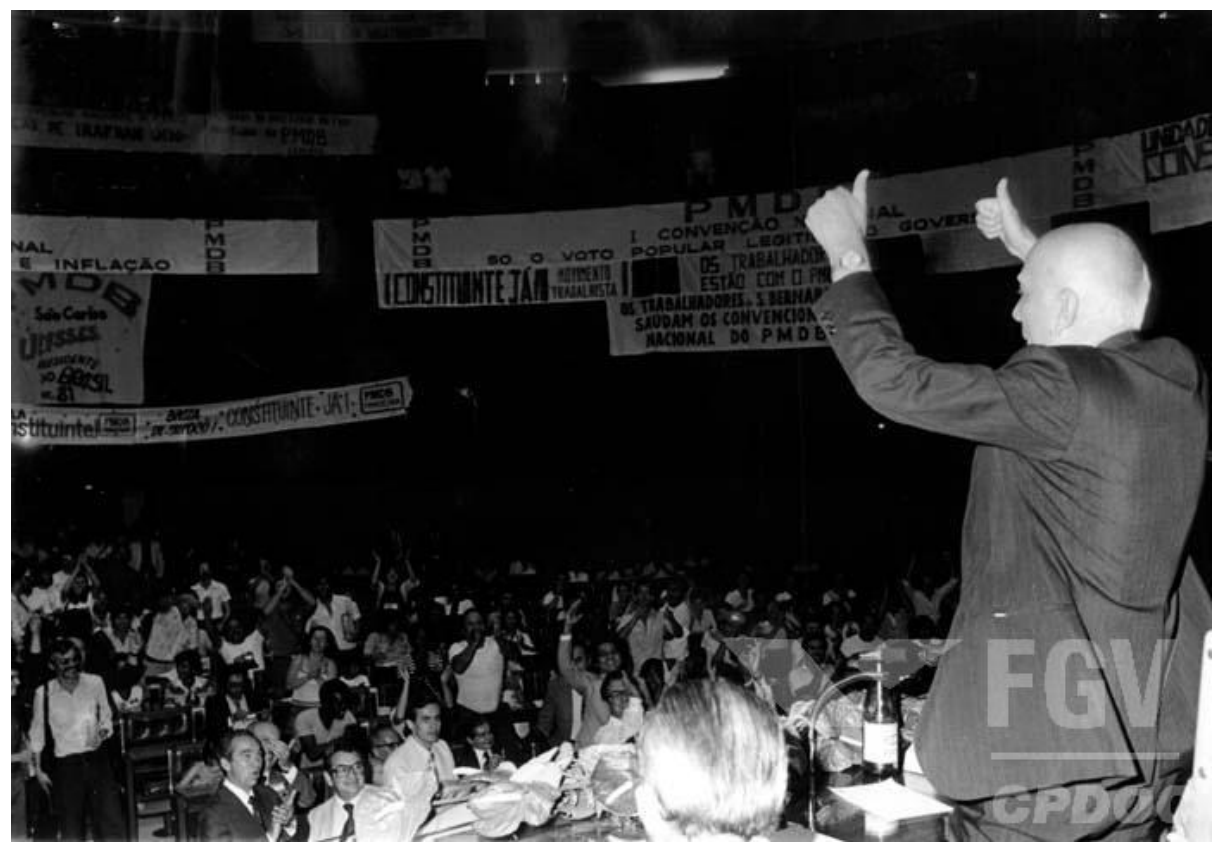

I Convenção Nacional do PMDB em 6 de dezembro de 1980. Acervo do $\mathrm{CPDOC} / \mathrm{FGV}$ 


\section{Capítulo 3 \\ Aproximação e incorporação do Partido Popular (1981-1982)}

Para compreender o que diferenciava o PMDB do Partido Popular (PP) no início do período pluripartidário deve-se conhecer, primeiramente, as diferentes circunstâncias do surgimento de cada partido. Em função disso, o primeiro objetivo deste capítulo será reconstruir a história do PP e descrever qual o perfil ideológico dos políticos que dele faziam parte antes de sua extinção formal. Dessa maneira, poderemos analisar quais foram as consequências do processo de incorporação desse partido para o PMDB, meses após o Regime Militar decretar o conjunto de medidas conhecido como "Pacote de Novembro".

O presente capítulo se divide em três partes. A primeira parte corresponde à Seção 1, na qual traçamos um perfil do que foi o Partido Popular em sua formação (um partido sobre o qual não há qualquer estudo de Ciência Política). A segunda parte corresponde às Seções 2 e 3, nas quais analisamos como se deu o processo de aproximação entre PP e PMDB. E, por fim, a terceira parte corresponde à Seção 4, na qual apresentamos as consequências da incorporação para a composição dos dois principais órgãos internos de decisão do PMDB, a saber, seu Diretório Nacional e sua Executiva Nacional, e também para uma desfiguração regional do partido.

1. A formação do PP: composição interna, posicionamento ideológico e organização nacional

Mesmo sendo o PP um partido bastante peculiar na história brasileira, não há qualquer pesquisa na Ciência Política que o tenha como objeto de estudo (Marques e Flesicher, 1999, p. 16). Relativamente relevante no cenário parlamentar durante sua curta 
existência (sempre se mantendo como a terceira maior bancada do Congresso), o partido se extinguiu antes mesmo de ter sido testado eleitoralmente. Seu "Manifesto de Fundação" data de 20 de dezembro de 1979, e sua extinção oficial se deu no dia 2 de março de 1982, quando o TSE reconhece seu processo de incorporação ao PMDB, pouco após o anúncio da Reforma Eleitoral conhecida como "Pacote de Novembro". O partido representa, assim, uma efêmera experiência partidária em meio ao processo de abertura.

O objetivo subjacente dos dois principais estrategistas políticos do governo Figueiredo (o então Ministro da Justiça Petrônio Portella e o Ministro-chefe do Gabinete Civil Golbery do Couto e Silva) quando elaboraram e encaminharam seu anteprojeto de reforma partidária ao Congresso era o de criar um sistema partidário que contivesse cinco partidos no máximo, dividindo a oposição e mantendo os governistas reunidos em uma só sigla. Como vimos no Capítulo 2, essa estratégia foi bem sucedida, salvo pela criação do PT, uma "anomalia" pela qual o Regime não esperava ${ }^{95}$. Com a criação de um pluripartidarismo moderado o Regime esperava criar também um partido de centro que atuasse como uma “oposição confiável”, que serviria para articular e possivelmente compor com o partido do governo nas futuras eleições em nível federal, e ao mesmo tempo poderia dividir as forças de oposição em nível estadual (Fleischer, 1988, p. 77). Esse partido seria uma articulação das forças liberais-conservadoras segundo Kinzo (1988, p. 209), ou então do "centro liberal" na visão de Sadek (1993, p. 16), congregando dissidentes arenistas e moderados/liberais emedebistas (Trindade, 1985, p. 20), que criariam um partido para ocupar um espaço inexistente durante a vigência do bipartidarismo.

\footnotetext{
${ }^{95}$ Sobre o caráter "anômalo" do PT na formação do sistema pluripartidário brasileiro, ver Keck (1991) e Meneguello (1989).
} 
Ao longo do processo de reforma partidária, esse partido de centro se materializou na criação do Partido Popular ${ }^{96}$. A literatura de Ciência Política sobre os partidos brasileiros apresenta algumas características dispersas, atribuídas a esse partido. Na visão de Keck (1991,p. 108), o PP representou a agremiação das elites mais conservadoras da antiga oposição (que se agrupava em torno do MDB). Para Schmitt (2000, p. 49) o partido seria equidistante da situação pedessista e da oposição peemedebista. Lima Jr. (1993, p.27) acha que o PP fez parte de um processo de acomodação das elites na mesma linha que seguiram futuramente PFL e PSDB: antes que o barco afunde, é melhor trocá-lo. A mesma visão é corroborada por Hagopian (1996, p. 216), para quem “o PP promoveu uma oportunidade de pular de um navio que naufragava para aterrissar em terra firme" (tradução minha). Para Carlos Estevam Martins (entrevista ao Folhetim, 24/02/1980, p. 6), o PP era o único partido que se apresentava como alternativa real de poder, perfeitamente aceitável pelo sistema burocrático-militar, pelo fato de ser uma alternativa dentro das classes dominantes.

Os dados apresentados nas Tabelas 5 e 6 do Capítulo 2, a respeito da nova composição partidária do Congresso após a Reforma Partidária, demonstram o perfil daqueles que formaram o PP. Entre os três principais partidos (PDS, PMDB e PP), o Partido Popular era o que apresentava a composição mais equilibrada entre políticos que haviam composto os extintos MDB e Arena. Como vimos, $59 \%$ de sua bancada na Câmara dos Deputados era composta por ex-emedebistas e $41 \%$ por ex-arenistas. No Senado a proporção era exatamente de $50 \%$ de ex-emedebistas e $50 \%$ de exarenistas. Essa composição equilibrada entre os dois partidos extintos demonstra que a característica atribuída ao PP por Trindade (1985, p. 20), de ser uma junção de governistas e oposicionistas, encontra respaldo na realidade empírica.

\footnotetext{
${ }^{96}$ Sobre os primeiros debates em torno da criação de um partido de centro durante o ano de 1979, ver reportagem publicada na Revista Veja, edição 562, 13 jun. 1979, p.20-21
} 
Com relação ao seu posicionamento político-ideológico de centro, as declarações de alguns políticos da época mostram que o partido procurava ocupar o espaço à direita do PMDB e à esquerda do PDS, ou seja, ao centro. Por exemplo, para Olavo Setúbal, Presidente do PP paulista, o partido seria o "fiel da balança" 97 das futuras eleições, um "algodão entre cristais (no caso, PDS e PMDB)" 98 , "um partido de centro, que tem um diálogo à esquerda e à direita" 99 . Ou ainda, na visão de Herbert Levy, fundador do Partido Popular, "seu propósito (ao coordenar uma dissidência da Arena) era formar um partido de centro, liberal, equidistante dos extremos, capaz de realizar uma política de justiça social sem demagogia"100. E, finalmente, segundo o próprio Tancredo Neves, o principal articulador do Partido, “o PP seria o partido da reordenação institucional do Brasil, na lei e na ordem, sem ódios nem revanchismos. (...). Seria o instrumento de transição pacífica do regime autoritário para o democrático"101.

Os dois principais articuladores do PP foram o Deputado e exgovernador de Minas Gerais Magalhães Pinto (diretor do Banco Nacional, forte eleitoralmente e economicamente desde os tempos de UDN - Benevides,1981, p. 232), e o Senador, também mineiro, Tancredo Neves (político experiente, ex-PSD, que exercera o cargo de Primeiro Ministro durante o curto período parlamentarista do regime pré-64). A força organizativa principal do partido era definitivamente Minas Gerais (Hagopian, 1996, pp. 216-217), mas também o Rio de Janeiro tinha importância, o que acabou por deixar o PMDB relativamente enfraquecido naqueles estados. Conforme mostrado no capítulo anterior, o PMDB conseguiu organizar diretórios municipais em apenas $20 \%$ dos municípios mineiros - Tabela 7 - e perdeu boa parte de sua bancada fluminense para o PP.

\footnotetext{
${ }^{97}$ Jornal da Tarde, $12 / 11 / 1980$

${ }^{98}$ Revista Veja, edição 694, 23 dez. 1981, p.3-4-6

${ }^{99}$ Folha de S. Paulo, 11/05/1981, p.4

${ }^{100}$ Folha de S. Paulo, $14 / 03 / 1982$, p.10

101 Folha de S. Paulo, 16/08/1980, p. 4
} 
Ademais, lideranças locais importantes em outros Estados contribuíram para a construção do partido. Entre os exoposicionistas, pertencentes ao extinto MDB, temos: no Rio de Janeiro o governador Chagas Freitas (que, como fora mostrado no capítulo anterior, levou consigo boa parte da bancada fluminense do MDB para o $\mathrm{PP}^{102}$ ); em Santa Catarina, o senador Evilásio Vieira; em Pernambuco o Deputado Federal Thales Ramalho e no Rio Grande do Norte o ex-deputado federal Aluísio Alves. Entre os políticos ex-arenistas que articularam o PP muitos haviam sido exgovernadores nomeados pelo Regime Militar: no Estado de São Paulo, o ex-governador Paulo Egídio, o ex-prefeito da capital Olavo Setúbal (proprietário do Banco Itaú), o ex-presidente da Arena paulista Cláudio Lembo e os Deputados Federais Herbert Levy e Caio Pompeu; no Rio Grande do Sul, o ex-governador Sinval Guazzelli; no Paraná, o ex-governador Jaime Canet; em Goiás, o ex-governador Irapuan Costa Júnior e na Bahia, o exgovernador Roberto Santos (inimigo político do grupo liderado por Antônio Carlos Magalhães do PDS).

Devido à sua formação baseada em diferentes forças exemedebistas e ex-arenistas, o Partido Popular apresentava uma forte heterogeneidade. Em São Paulo, por exemplo, os políticos do partido apresentavam um discurso que buscava representar a classe média para fazer com que o PP se tornasse o partido do "capitalismo moderno", do liberalismo e do empresariado urbano, sendo esses os setores que ali construíam o Partido (como Olavo Setúbal e Cláudio Lembo). Porém, em muitos Estados o PP apresentava uma forte marca conservadora e agrária, sendo formada por espólios da antiga Arena, como era o caso do PP paranaense, formado em torno de Jaime Canet, agropecuarista e um dos maiores produtores de café daquele Estado ${ }^{103}$. Esse aspecto teria posteriormente consequências importantes para o PMDB, quando o

\footnotetext{
${ }^{102} \mathrm{O}$ que gera inclusive uma disputa pela herança da antiga sede do MDB Fluminense.

${ }^{103}$ Verbete "Jaime Canet Júnior" do Acervo CPDOC/FGV
} 
TSE reconhece oficialmente a incorporação dos quadros do PP no início de 1982, o que será analisado na seção 4.

O primeiro documento emitido publicamente pelo Partido Popular data de 20 de dezembro de 1979, mesmo dia em que a lei de reforma partidária foi sancionada ${ }^{104}$. Tratava-se de um "Programa Básico" com 28 pontos programáticos, mais conciso do que aquele divulgado pelo PMDB na mesma data e que foi apresentado no Capítulo $2^{105}$. O documento foi lido pelo Deputado Magalhães Pinto na sede da Associação Brasileira de Imprensa, no Rio de Janeiro, e conta com apenas algumas páginas. Nele, o partido procura se colocar como oposição ao governo, fazendo críticas às suas políticas institucional, econômica e social, mas com um tom mais moderado do que as críticas presentes no documento emitido pelo PMDB. Isso mostra o quanto, desde suas origens, ambos PMDB e PP procuram se diferenciar no novo cenário pluripartidário que surgia, cada qual procurando ocupar o seu espaço e construir uma identidade própria dentro do espectro político.

Por exemplo, enquanto o PMDB defende unanimemente a convocação de uma Assembleia Constituinte (expressando isso em seu programa e em seu Manifesto de Fundação), no PP esse tema não é consensual. Havia quadros no partido que argumentavam preferir que o próprio Congresso reformasse a Constituição (como era o caso do Senador Tancredo Neves). O Programa divulgado pelo PMDB argumenta que deveria haver uma maior participação popular nas esferas de decisão e participação política (incluindo os partidos políticos), incentivando a sociedade civil organizada, enquanto que esse ponto não era tocado no Programa do PP. São

\footnotetext{
${ }^{104}$ Assim como o PMDB, o PP já se articulava mesmo antes do sancionamento da Reforma Partidária para se constituir como um futuro partido de oposição, mas que fosse de Centro neste caso. Revista Veja, edição 562, 13 jun. 1979 , p.20-21

105 Assim como o documento "Proposta de debate" do PMDB, não obtivemos, por meio de consulta ao TSE, essa primeira proposta programática do PP porque ela não constava no arquivo do partido. Porém, as edições de 21/12/1979 do jornal Folha de S. Paulo, e de 22/12/1979 do jornal O Estado de S. Paulo, reproduzem uma série de trechos do documento, que nos serviram como base para a análise esta seção.
} 
dignas de nota as diferenças no campo econômico dos dois programas, demonstrando a maior moderação das críticas feitas pelo PP ao Regime, em relação àquelas feitas pelo PMDB: enquanto o PP reivindicava a restrição do “capitalismo estatal" apenas aos setores indispensáveis, o PMDB coloca como condição fundamental para o cumprimento de seu programa a restrição do poder decisório sobre o campo econômico apenas ao Estado. Evidentemente há também pontos nos dois programas que aproximam PMDB e PP naquele momento, como, por exemplo, o diagnóstico de uma crise no país, assim como algumas soluções para ela: eleições diretas para todos os cargos, cumprimento do calendário eleitoral e devolução das prerrogativas perdidas pelo Poder Legislativo.

Seguindo o seu processo de regulamentação, em 10 de Janeiro de 1980 o PP elegeu em sua primeira reunião oficial os integrantes da Comissão Nacional Provisória do partido. Integram a Comissão: os Deputados João Menezes (do Pará), Miro Teixeira (Rio de Janeiro, nomeado Secretário Geral Provisório), Magalhães Pinto (Minas Gerais, Presidente Honorário), Senadores Tancredo Neves (Minas Gerais, nomeado também como Presidente Provisório), Alberto Silva (Piauí), Afonso Camargo (Paraná), Evelásio Vieira (Santa Catarina), Gastão Muller (Mato Grosso), ex-governador Aluisio Alves (Rio Grande do Norte), ex-governador Roberto Santos (Bahia) e o ex-prefeito Olavo Setúbal (São Paulo) ${ }^{106}$.

Alguns dias após a reunião, Cláudio Lembo (ex-presidente da Arena de São Paulo) publica um editorial na Folha de S. Paulo com caráter de manifesto, expressando o perfil ideológico liberal do novo partido que surgia:

“Entre os equívocos verificados, nestes últimos 15 anos, encontra-se um, em termos de nação, fundamental. (...). Este engano foi o sufocamento das

\footnotetext{
${ }^{106}$ A respeito da relação entre Olavo Setúbal e o PP, o site do político disponibiliza uma série de entrevistas e documentos seus a respeito do tema. O político tornou-se presidente do Partido no estado de São Paulo. Ver http://www.olavosetubal.org.br/
} 
raízes liberais existentes no Brasil.(..) Com o surgimento oficial do bipartidarismo em 1966, este segmento liberal da sociedade foi esmagado. (...) Esta violência gerou, desde logo, o aparecimento de duas facções. (...) Daí surgiu o radicalismo. A situação tornou-se insustentável. A nação exigiu reformas. (...) É neste exato instante que se recorporifica o pensamento liberal".

“Agora, pois, quando o pesadelo do autoritarismo vai se esvaindo - e os liberais jamais se calaram figuras idôneas da vida pública vão se reagrupando, em torno dos ideais liberais modernos, e vai surgindo, em cada município, de maneira espontânea, e nos parlamentos, como situação jurídica formal, o PP, Partido Popular"

"Os liberais, já declarados, pedem, agora, aos seus iguais, ainda silenciosos, que venham se juntar a eles para a manutenção dos princípios comuns." ("Por que PP?", Folha de S. Paulo 20/03/1980, p. 3)

Algumas semanas depois, no momento de reabertura do Congresso, em 1980, o primeiro "bloco parlamentar" congregando aqueles que pretendiam se filiar ao PP era composto por 81 deputados e 8 Senadores. Esse número foi se reduzindo gradualmente na Câmara, mas aumentou no Senado, chegando a 66 Deputados e 10 Senadores em Dezembro de 1980. Essa flutuação nos quadros do partido em seu primeiro ano se deu por dois motivos principais.

O primeiro deles foi uma mudança na estratégia de reformulação partidária por parte do Regime ${ }^{107}$. Com a adesão expressiva de dissidentes arenistas ao Partido Popular, o Regime passou a temer que seu partido de sustentação passaria à condição

\footnotetext{
${ }^{107}$ Sobre esta passagem, ver Fleischer $(1982,1988 b)$.
} 
de maioria simples no Congresso. Assim, procurou fortalecer o PDS, sugando quadros de PP e PMDB, através do oferecimento de cargos e secretarias ${ }^{108}$. O segundo motivo foi o falecimento do Ministro da Justiça Petrônio Portella, um dos principais articuladores do partido, que deixa "órfão" um bloco de políticos que o havia seguido rumo ao PP.

Com relação à sua atuação parlamentar em seu primeiro ano, o partido muitas vezes demonstrava o seu caráter centrista. Ora o partido se aproximava do partido governista, o PDS (por exemplo, quando da votação acerca da autorização para o presidente Figueiredo realizar visita ao Chile, governado por Pinochet, ocasião na qual o quórum e a votação só foram garantidos pelos deputados do PP), ora se aproximava dos outros partidos da oposição (por exemplo, fazendo coro às reivindicações pela revogação da Lei Falcão ${ }^{109}$ ). Porém, sua atuação parlamentar não era sua única preocupação naquele ano.

Durante os anos de 1980 e 1981 o partido dividiu suas atenções entre sua atuação no Congresso e sua estruturação nacional, tal como fizera o PMDB em 1980. Em seu processo de organização, o PP acaba por se tornar um dos partidos com maiores bases municipais do Brasil ${ }^{110}$. No primeiro semestre de 1981, o PP realiza suas Convenções, nos três níveis exigidos pela legislação, para se regulamentar formalmente junto ao TSE.

\footnotetext{
${ }^{108}$ Ibrahim Abi Ackel, Deputado Federal e futuro sucessor do Ministro da Justiça Petrônio Portella é um desses casos, que flerta com o PP mas acaba por aderir ao partido do governo.

${ }^{109}$ Sob orientação do então Ministro da Justiça Armando Falcão, foi elaborado, ainda em 1976, o Projeto de Lei da Reforma da Propaganda Eleitoral, que, alterando o Código Eleitoral, restringia o acesso dos candidatos aos meios de comunicação eletrônica, impedindo assim o livre debate, considerado um dos elementos determinantes da vitória oposicionista no pleito de 1974. O projeto de lei, que depois de aprovado ficou conhecido como Lei Falcão, estipulava que as emissoras de rádio e televisão reservariam, nos dois meses anteriores à realização dos pleitos, espaços na programação destinados à propaganda eleitoral gratuita, que deveria se reduzir à apresentação dos currículos e plataformas dos candidatos e de seus retratos, no caso da televisão, sob a fiscalização direta e permanente da Justiça Eleitoral (Acervo CPDOC/FGV - Verbete "Armando Falcão"). Sobre o impacto da Lei Falcão nas eleições até 1978 ver Duarte (1980).

${ }^{110}$ Levando o seu presidente Tancredo Neves a declarar que o PP seria o novo PSD do período pós-1979, um claro exagero.
} 
No dia 29 de março o Partido Popular elege diretórios em 2.145 municípios, em 19 Estados da Federação. Dessa maneira, o partido consegue cobrir mais de 55\% dos municípios brasileiros, tornandose o terceiro maior partido em número de bases municipais, além de ser também o terceiro maior em representação parlamentar. Os Estados com maior penetração do partido são Minas Gerais e Rio de Janeiro, como já dito, sendo que apenas nos Estados de Goiás, Acre e Alagoas o PP não realiza suas convenções naquela data.

Em 3 de maio de 1981, seguindo o processo de estruturação e regulamentação, o Partido realiza suas Convenções Estaduais em 18 estados (há problemas na formação de diretórios em Goiás, Amazonas, Acre, Espírito Santo e Alagoas). Nessa ocasião são definidos os titulares e suplentes dos Diretórios Regionais, os delegados a serem enviados à Convenção Nacional e ainda alguns futuros candidatos pelo partido para as eleições de 1982 (sobretudo para o cargo de governadores dos Estados).

Finalmente, no dia 7 de junho do mesmo ano, o Partido Popular realiza sua Convenção Nacional. Nela são escolhidos os membros do Diretório Nacional do Partido, com uma composição de 68 políticos (dos quais 44 eram deputados, 10 era senadores e 14 filiados notáveis), 22 suplentes e mais os cargos principais de direção de sua Executiva Nacional. É digno de nota que entre os 19 políticos que faziam parte de seu órgão máximo de direção, 12 eram ex-filiados a Arena e apenas sete eram ex-filiados ao MDB:

Presidente: Tancredo Neves

Presidente de Honra: Magalhães Pinto*

$1^{\circ}$ Vice-presidente: Aluisio Alves

$2^{\circ}$ Vice-presidente: Paulo Egídio*

$3^{\circ}$ Vice-presidente: Affonso Camargo

Secretário-geral: Miro Teixeira

$1^{\circ}$ Secretário: João Linhares*

$2^{\circ}$ Secretário: Jorge Vargas* 
$1^{\circ}$ Tesoureiro: Gastão Muller*

$2^{\circ}$ Tesoureiro: Alberto Silva*

Vogais: João Menezes, Antônio Mariz*, Celso Carvalho*, Antônio Moraes

Suplentes: Carlos Sant'Ana*, Márcio Macedo, Rubem Figueiró*, Louremberg Nunes Rocha*, Lúcia Viveiros*

Fonte: Pedido de Registro Definitivo - RGP n ${ }^{\circ} 40$ - Resolução/TSE $n^{\circ}$ 11.075

*Ex-arenistas

Superada a etapa da realização de suas Convenções, no dia 26 de junho de 1981 o PP ingressava junto ao TSE com a documentação necessária para a obtenção de seu registro definitivo ${ }^{111}$, sendo esse aprovado pelo Tribunal em 10 de setembro de $1981^{112}$. Porém, concomitantemente, intensificavam-se as conversas entre as cúpulas do PP e do PMDB visando uma possível fusão nacional entre os dois grupos. Antes de analisarmos as consequências da incorporação de um partido ao outro passemos primeiramente pela reconstrução do processo de aproximação gradual entre os dois partidos que, em sua gênese, apresentavam uma composição de forças políticas bastante distintas entre si.

2. O processo de aproximação entre os partidos

Institucionalmente, há uma gradual aproximação entre PP e PMDB, que começa em meados de 1980. Em um contexto de certa desconfiança por parte do $\mathrm{PMDB}^{113}$, os políticos mineiros são os principais interlocutores no início deste processo. O senador Itamar Franco, importante figura do PMDB em Minas Gerais, e

\footnotetext{
${ }^{111} \mathrm{O}$ PP tornou-se o quarto partido a requerer seu registro definitivo, tendo sido precedido por (pela ordem): PDS, PMDB e PTB.

${ }_{112}$ Pedido de Registro Definitivo - RGP n ${ }^{\circ} 40$ - Resolução/TSE n ${ }^{\circ} 11.075$

${ }^{113}$ Principalmente devido ao diálogo mais intenso que se dava entre o PP e o governo nos anos de $1980 \mathrm{e}$ 1981, e também por conta do posicionamento do PP em algumas votações polêmicas, como, por exemplo, a posição do partido em votar a favor de mensagem que autoriza a visita do então Presidente Figueiredo ao Chile, governado por Pinochet. A votação se deu em 24 de setembro de 1980.
} 
parte dos políticos que se autodenominavam “não-alinhados", de tendência mais liberal no partido, estabelecem um canal de diálogo com o PP, principalmente através dos deputados Carlos Cota e Luis Leal, do PP mineiro. Cria-se naquele estado a Comissão Interpartidária das Oposições, justamente para estabelecer uma articulação entre os dois partidos. Além dos parlamentares mineiros citados, outros políticos também procuram articular a fusão a partir das bases regionais, como foi o caso do senador peemedebista Humberto Lucena, da Paraíba, que reuniu as bancadas estaduais dos dois partidos em outubro de 1980 (meses antes da incorporação oficial) com o intuito de criar entendimentos entre as lideranças locais na sua atuação parlamentar.

Cabe ressaltar que a aproximação entre os partidos recémcriados não se restringia apenas ao PP e ao PMDB. Num período de grande flutuação dos quadros e de muitas incertezas quanto ao contexto no qual seriam realizadas as eleições de 1982 (caso elas não fossem adiadas como as de 1980), os líderes dos partidos oposicionistas mantêm contatos frequentes para debater possíveis fusões ${ }^{114}$. No contexto de grande insegurança institucional em que os partidos se encontravam, conforme o Regime sinalizava com alterações “casuísticas” na legislação eleitoral que pudessem prejudicá-los ou até inviabilizá-los (medidas estas que viriam a se materializar posteriormente no "Pacote de Novembro"), os partidos

\footnotetext{
${ }^{114}$ Franco Montoro (SP) e o senador Roberto Saturnino (RJ), deixaram as portas abertas do PMDB para o grupo liderado por Brizola desde que este começa a disputar a sigla do PTB com Ivete Vargas. Porém, como algumas tensões regionais e nacionais ficam evidentes neste processo (por exemplo, entre Leonel Brizola e o presidente do PMDB no Rio Grande do Sul Pedro Simon e, em nível nacional, a hostilidade da Tendência Popular à fusão com o grupo brizolista) essa possibilidade é descartada. Ao final, Brizola perde a sigla PTB para o grupo liderado por Ivete Vargas, opta por construir seu partido em torno de outra sigla, o PDT, e mesmo assim segue mantendo contatos com lideranças do PMDB.

Também é cogitada fortemente nos meses de maio e junho de 1981 uma fusão entre PP e PTB ( já registrado por Ivete Vargas naquele momento), diante das dificuldades que poderiam ser colocadas pelo governo à organização dos partidos. Com o intuito de realizar a fusão, seguiram-se inúmeras reuniões entre Tancredo Neves e os dois principais líderes no PTB naquele momento, Ivete Vargas e o expresidente Jânio Quadros. A proposta de fusão não foi em frente, sendo criticada por parte das lideranças pepistas por sentirem-se ameaçadas ao dividir o mesmo espaço político com a controversa figura do expresidente.
} 
passavam a dialogar mais ${ }^{115}$. Assim, o processo de aproximação entre os líderes de PP e PMDB se intensificava ou diminuía de acordo com as medidas adotadas pelo governo ${ }^{116}$.

No final de 1980, a Executiva do PP se reúne para debater pela primeira vez a proposta de fusão com o PMDB. Porém, naquele momento, a proposta acabou por ser esvaziada pelo seu presidente de honra, Magalhães Pinto. O político argumentava (e com razão) que a legislação apenas permitia a fusão de partidos que estivessem registrados, o que não era o caso do PP naquele momento. Com o passar dos meses e com o fim do processo de registro do Partido, os entendimentos entre PP e PMDB passam a ser mais frequentes, mas Magalhães Pinto mantem sua posição reticente quanto a incorporação ${ }^{117}$. Por sua vez, uma parte dos políticos do PMDB se mostrava reticente quanto à ideia de unir PP e PMDB, em 1980, sobretudo pelo forte rechaço a alguns quadros de perfil conservador do PP e que poderiam transformar o perfil ideológico almejado pelo PMDB. Exemplo disso seria a vinda para a legenda do governador do Rio de Janeiro, Chagas de Freitas, e de alguns dos ex-governadores que foram nomeados pelo Regime Militar e que faziam parte da cúpula do $\mathrm{PP}^{118}$.

O tema que acaba por aproximar os dois partidos e que se mantém em debate durante todo o ano de 1981 seria uma possível Reforma Eleitoral, futuro estopim da formalização da incorporação de um partido ao outro. De fato, os três principais partidos, PDS, PMDB e PP, apresentam no Congresso uma série de propostas sobre

\footnotetext{
115 A literatura que trata a respeito do regime militar classifica como "casuísmo" todas as medidas implantadas com o intuito de beneficiar o partido governista, seja a Arena no período 1965-79, ou o PDS, de 1979 a 1984.

${ }^{116}$ Esse ponto de vista era também compartilhado por algumas lideranças da época, como Magalhães Pinto em entrevista à Folha de S. Paulo, 1/10/1980, p.4.

${ }^{117}$ Uma posição que passa a ser claramente contrária quando da efetivação da incorporação do PP e que leva o político a se filiar ao partido governista depois de alguns meses.

${ }^{118}$ Esse rechaço a quadros de perfil conservador também ficou evidente quando da tentativa de Jânio Quadros de se filiar ao PMDB em 1981. O partido temia que com o ingresso de Jânio e uma série de seguidores seus - organizados principalmente em torno do Movimento Popular Jânio Quadros - o partido passaria por uma descaracterização muito profunda do seu perfil ideológico. Para uma descrição detalhada da tentativa de filiação de Jânio ao PMDB ver Delgado (2006).
} 
o assunto e, posteriormente, debatem em seu interior as medidas que se encontram em tramitação, buscando definir qual seria sua posição com relação a ela.

No primeiro semestre de 1981, PP e PMDB aproximam-se na sua atuação parlamentar, na tentativa de aprovar um projeto do senador Humberto Lucena (PMDB/PB) autorizando o sistema de coligações eleitorais e revogando as sublegendas ${ }^{119}$. A legislação a respeito do tema deixava margem a uma dupla interpretação e os partidos oposicionistas temiam (e com razão, como a história futuramente iria mostrar) que o governo tocasse neste tópico em sua futura Reforma. A estratégia dos partidos de oposição no Congresso era obstruir as votações no Senado, pedindo a verificação de quórum a cada sessão, para forçar um posicionamento do governo quanto à futura Reforma. Após inúmeras obstruções das bancadas dos partidos oposicionistas ${ }^{120}$, a proposta acabou por ser rejeitada em votação, mas o governo se comprometeu perante as oposições a apresentar sua proposta de Reforma Eleitoral até o dia 30 de junho daquele ano, última sessão do semestre (o que, ao final, não foi cumprido).

O governo, naquela votação, sinalizava às oposições que não haveria a possibilidade de coligações nas futuras eleições, fazendo com que a tese de fusão das oposições ganhasse força. Em meados de maio, surge no Congresso o "Movimento Pró-fusão das

\footnotetext{
${ }^{119}$ Outra tema que aproximam PMDB e PP na sua atuação parlamentar no ano de 1981 e que aqui não será analisada é a tentativa de barrar (desta vez com sucesso), qualquer tentativa do governo de aprovar uma proposta prorrogando o mandato dos deputados federais e senadores, adiando-as para 1984, assim como fez o governo com relação às eleições municipais que deveriam ter ocorrido em 1980. Neste caso é o PP que toma a frente do tema, com o senador Afonso Camargo (PP/PR) elaborando documento e colhendo assinaturas dos senadores demarcando posição contrária à aprovação da proposta governista sobre o tema. Muitos políticos da oposição encaram a questão com ceticismo, acreditando que o governo ainda não tem uma postura definida a respeito da reforma eleitoral e que a prorrogação é uma das possibilidades na mesa. Porém, no segundo semestre, com a edição do "Pacote Eleitoral" a possibilidade de prorrogação dos mandatos é retirada da mesa, e surgem assim outros problemas para as oposições.

${ }^{120}$ Nos meses de abril e maio de 1981, o Senado Federal chega a ficar 45 dias consecutivos sem sessões por conta das obstruções de PP e PMDB enquanto que na Câmara esse número chega a 7 dias. As obstruções contavam com o fato de que o governo não conseguia mobilizar todos os seus senadores para estarem presentes nas sessões do Senado. Com um quórum insuficiente, a oposição pedia a verificação dos Senadores presentes e isso impedia a Sessão. As obstruções só foram suspensas em 26 de junho de 1981, fazendo com que o Senado terminasse aquele semestre tendo realizado pouquíssimas sessões.
} 
Oposições", congregando mais de 150 deputados e senadores do PP e do PMDB, que elaboram um documento intitulado "Fora da Fusão não há salvação", retomando a ideia de se unirem. Entre os que assinam o documento estão importantes lideranças dos dois partidos, como o Senador Itamar Franco, presidente do PMDB mineiro, o Deputado Roberto Cardoso Alves, membro do Diretório Nacional do PMDB, e Herbert Levy, vice-líder e também um fundador do PP. Apesar desse amplo apoio de suas bancadas a proposta não conta com o apoio de parte da cúpula dos dois partidos, principalmente do $\mathrm{PMDB}^{121}$, que em seu discurso argumentavam ser melhor aguardar pela definição do governo quanto à reforma eleitoral que estava por vir. Após a coleta de assinaturas, o documento foi entregue para a apreciação dos presidentes do PP e do PMDB, respectivamente Tancredo Neves e Ulysses Guimarães, como uma forma de pressão por parte das representações dos partidos sobre suas respectivas cúpulas. Ambos os presidentes, porém, encaravam a fusão com ressalvas em meados de 1981: Ulysses se mostrava contrário à fusão, por conta dos entraves burocráticos, e Tancredo argumentava que o Regime poderia promover um retrocesso no processo de abertura política ao sentir-se ameaçado de perder o controle desse processo ${ }^{122}$.

É interessante notar que a proposta de fusão das oposições naquele momento surge apenas a partir das bases parlamentares filiados ao PP e ao PMDB. Os outros partidos mais claramente identificados com a oposição, PT e PDT, naquele momento se colocavam contrários à proposta de reaglutinação das oposições ${ }^{123}$, apesar de ambos enfrentarem maiores dificuldades para se

\footnotetext{
${ }^{121}$ Ulysses Guimarães declara que "Nem sabe o que fará com o documento quando lhe entregarem" e Pedro Simon argumenta que a proposta "não pode partir de agremiações que estão prestes a obter seu registro definitivo do TSE, como é o caso do PMDB.” Estado de São Paulo, 23/05/1981, p. 4

${ }^{122}$ Folha de S. Paulo: 11/06/1981, p. 5

${ }^{123}$ O presidente nacional do PT, Luís Inácio Lula da Silva, declara à época que a tese da fusão das oposições se dá por "interesses eleitoreiros" e acabaria por marginalizar as novas lideranças políticas que surgiram com o pluripartidarismo, como ele próprio. Estado de São Paulo, 23/05/1981, p. 4 A Executiva Nacional Provisória do PT também emite nota declarando que "no curto prazo o governo pode ganhar com a divisão das oposições, mas no longo prazo, haverá instrumentos eficazes para se opor ao regime". Folha de S. Paulo 29/05/1981.
} 
estruturar nacionalmente e terem menores chances de superar as barreiras colocadas pela legislação eleitoral do que PP e PMDB. O PMDB, naquele momento, era o partido de oposição que mais havia avançado no seu processo de regulamentação - aguardava apenas a resposta do TSE para obter seu registro definitivo - e possuía também as maiores bancadas oposicionistas no Congresso. Por sua vez, o PP já possuía uma ampla base de sustentação no nível local (lembrando que no momento de suas Convenções o PP possuía diretórios municipais em mais da metade dos municípios brasileiros) e a terceira maior bancada do Congresso. A despeito disso, somente esses dois partidos dão prosseguimento à ideia de se unir sob uma só legenda durante o primeiro semestre daquele ano.

Contudo, em maio de 1981, uma nota divulgada à imprensa pelo Deputado Tarcísio Delgado, membro da Executiva Nacional do PMDB, demonstra uma mudança na estratégia dos líderes peemedebistas. Em um cálculo político bastante refinado por parte de sua cúpula, define-se publicamente a posição que o partido passaria a adotar em relação à união das oposições:

“Fusão é utopia e casuísmo: o PMDB continua de braços abertos para todos" ${ }^{124}$.

O PMDB, a partir daquele momento, “deixava suas portas abertas" para os que quisessem se incorporar a ele, e não mais cogitava uma "fusão" entre os partidos. Sendo o partido que se encontrava no estado mais avançado de regulamentação perante o TSE, o PMDB possuía um forte poder de barganha perante o PP, que também cogitava essa união e que poderia levar àquele uma ampla rede organizativa (como vimos na primeira seção deste capítulo).

Em resposta à pressão de suas bancadas, que se articulavam em torno do “Movimento Pró-fusão", os presidentes de PP e PMDB decidem se reunir durante o recesso parlamentar de Julho de 1981 ,

${ }^{124}$ Folha de S. Paulo, 23/05/1981, p. 4 
e convocam os presidentes dos outros partidos em formação para discutir a proposta de fusão de todas as oposições. Tal medida desperta temores em alguns setores do Regime, temerosos de ver fracassar seu propósito de fragmentar partidariamente a oposição. Antes da realização da reunião, a Executiva Nacional do PMDB se reúne e emite uma nota pública na qual "aceita a reaglutinação de todas as siglas oposicionistas através de um pacto que preserve as propostas partidárias já colocadas”. Por sua vez, o PP alegara que iria à reunião “desarmado, sem posições e reivindicações”, nas palavras de seu presidente Tancredo Neves ${ }^{125}$.

$\mathrm{Na}$ reunião, ocorrida na sede da seção paulista da OAB, estiveram presentes representantes de PP, PMDB, PTB e PT, cada qual com seu respectivo presidente e algumas outras figuras proeminentes. O PDT optou por não enviar qualquer representante, argumentando que não se dispunha a dialogar com o PTB, classificado por Leonel Brizola como o "PTB Golberyano"126. Na ocasião da reunião, o Deputado Roberto Cardoso Alves (PMDB/SP), um dos principais articuladores da união das oposições na Câmara dos Deputados, é impedido de participar da reunião principal, mas isso não o impediu de apresentar à imprensa a proposta de “incorporação" dos outros partidos ao PMDB, ao invés de uma fusão de todas as oposições ${ }^{127}$.

Essa proposta, naquele momento, já possuía certa sustentação, já que no dia 10 de julho o Partido Popular anunciava sua extinção no Estado do Mato Grosso do Sul e a transferência de todos os seus filiados para o PMDB. Em novembro do mesmo ano, semelhante processo ocorreria em outros estados. Em Sergipe, o PMDB incorporou três políticos pepistas em seus quadros, os deputados federais Tertuliano Azevedo e Celso Carvalho e o Senador Gilvan Rocha (que também detinha a $2^{a}$ Vice-Presidência da casa) e na

\footnotetext{
${ }^{125}$ O Estado de S. Paulo 15/07/1981, p. 4

${ }^{126}$ Folha de S. Paulo, 11/07/1981, p.4 e O Estado de S. Paulo 15/07/1981, p.4

${ }^{127}$ O deputado é apontado por Melhem (1998, p. 116-117) como um deputado indiferente ao autoritarismo e que ingressa no MDB apenas por ter perdido espaço na ARENA.
} 
Paraíba, onde havia sido feito um acordo entre os partidos para definir qual deles lançaria um candidato ao cargo de governador e qual lançaria aos cargos legislativos. Tais trâmites consistiam no início do processo de aproximação das bases regionais dos partidos com vistas à incorporação.

Como resultado dessa reunião em julho de 1981, os partidos emitem uma nota pública definindo quais serão os objetivos das oposições quanto à sua atuação conjunta. Nela, foram definidas como metas a luta por eleições diretas em todos os níveis, a revogação dos instrumentos de exceção, como a Lei de Segurança Nacional, e por fim, apontam: "Com vistas a estes objetivos, os partidos de oposição manifestam o seu propósito de prosseguir, em novos encontros, na elaboração de um plano de atuação em comum e, se necessário, de promover a sua completa unidade de ação" ${ }^{128}$. Dessa maneira era aberto simbolicamente um canal de diálogo entre as oposições, ao mesmo tempo em que era indicada a possibilidade de uma fusão total das oposições, a depender do que o governo definisse em sua futura reforma eleitoral ${ }^{129}$.

$\mathrm{Na}$ próxima seção, demonstraremos como essa proposta de "fusão" de todas as oposições acabou por resultar na ideia de “incorporação” apenas do PP pelo PMDB.

\section{Um novo "Pacote Eleitoral" põe fim ao PP}

No segundo semestre de 1981, após o retorno do recesso parlamentar (durante o qual ocorrera a reunião das oposições para debaterem a proposta de fusão), governo e oposição apresentaram na Câmara seus projetos de Reforma Eleitoral e reacenderam os

\footnotetext{
${ }^{128}$ A íntegra do documento se encontra no ANEXO 3.

${ }^{129} \mathrm{Em}$ meio aos debates sobre a reforma eleitoral, renovam-se no ano de 1981 as lideranças e mesas diretoras do Congresso Nacional, momento no qual o PMDB procurava adotar uma postura mais combativa no Parlamento, escolhendo lideranças do campo da sua esquerda para liderar suas bancadas: na Câmara o líder do partido se torna o deputado gaúcho Odacir Klein (identificado com a "Tendência Popular", substituindo o ex-líder paulista Freitas Nobre) e no Senado o novo líder é o pernambucano Marcos Freire (um autêntico histórico, que substitui o gaúcho Paulo Brossard). No caso do PP, o Senador catarinense Evelásio Vieira passa a comandar a bancada do Senado, e o deputado paulista Thales Ramalho é o líder do partido na Câmara.
} 
debates acerca das regras que estariam em vigência para o pleito de 1982. Os impasses eram inúmeros e não havia consenso nem mesmo dentro do próprio PDS a respeito de quais seriam as regras vigentes no jogo eleitoral. Por fim, o projeto inicial apresentado pelo governo era menos impactante do que previam as oposições (dentre as medidas, o projeto estendia as sublegendas para as eleições para governador), mas surgem divergências por parte de governistas e opositores quanto à fixação da data para o pleito. Alguns setores do Palácio do Planalto defendiam o desdobramento do pleito em duas datas, segundo eles para facilitar a compreensão do eleitor sobre os cargos em disputa, enquanto que o próprio PDS no Congresso se mostra contrário a tal medida. Por sua vez, o projeto inicial de Reforma apresentado pelas oposições era mais amplo, propondo a revogação da Lei Falcão e das sublegendas, assim como uma série de mudanças no Código Eleitoral, entre outras medidas.

Seguiram-se meses de impasses no Congresso Nacional em torno dessas matérias, durante os quais obstruções e "rachas" dentro dos principais partidos ocorreram, sem que houvesse consenso nem mesmo depois das inúmeras reuniões de negociação entre o Ministro da Justiça Ibraim Ackel, o Ministro da Casa Civil Leitão de Abreu, lideranças do PDS e os líderes dos partidos de oposição. Finalmente, no dia 25 de novembro, poucos dias antes do recesso de fim de ano de 1981, o Presidente Figueiredo convocou seus ministros para uma reunião extraordinária. Ao final dela, o portavoz do governo Carlos Atila anunciava à imprensa: "Diante dos impasses nas negociações com as oposições, o Presidente Figueiredo tomou a decisão de propor (sic) a sua Reforma Eleitoral" ${ }^{130}$. Foram levadas a público, naquele momento, as novas Leis Eleitorais que iriam reger as eleições de 1982, em uma clara demonstração de que o Poder Executivo e o Regime desejavam manter as rédeas do processo de abertura ${ }^{131}$. Como consequência,

\footnotetext{
${ }^{130} \mathrm{O}$ texto integral da nota produzida pelo Palácio do Planalto encontra-se reproduzido no ANEXO 4

${ }^{131}$ Naquele momento, o PDS se mostrava cada vez menos coeso em sua atuação. Poucos meses antes, o Congresso rejeitou a emenda proposta pelo governo que estendia as sublegendas para as eleições para o
} 
rapidamente se intensificou o processo de aproximação nacional entre PP e PMDB, iniciado meses antes em nível regional.

A imposição dessa nova reforma eleitoral, em novembro de 1981, ficaria conhecida na história política brasileira como o "Pacote de Novembro", e foram o primeiro passo de mais uma série de casuísmos do Regime Militar que visavam beneficiar o partido do governo nas futuras eleições ${ }^{132}$. Porém, diferentemente da Reforma Partidária de 1979, que ocasionou a criação de novas legendas e a divisão da oposição, a consequência principal desta vez seria a extinção de uma sigla partidária (o PP) e o fortalecimento de uma sigla oposicionista (o PMDB).

A aprovação do Pacote se daria apenas por decurso de prazo no ano seguinte, ainda que houvesse uma Convocação Extraordinária do Congresso para votar a matéria em seu recesso. O Pacote impôs uma série de medidas que deveriam ser adotadas para as eleições de 1982 $2^{133}$ : a vinculação do voto do eleitor em todos os níveis, sob pena de nulidade do voto (o que obrigava o eleitor a votar em um mesmo partido para todos os cargos, os quais, pelo fato de as eleições de 1980 terem sido adiadas, seriam os de vereador, prefeito, deputado estadual e federal, senador e governador), obrigatoriedade de os partidos apresentarem candidatos para todos os cargos em disputa (fato que, na prática proibia coligações e alianças partidárias nas disputas eleitorais), e a condição de nãodesistência das candidaturas a governador, sob pena de nulidade dos votos dados ao partido" ${ }^{134}$. O governo "sugeria" também que a

cargo de governador, a primeira derrota de um projeto do governo na Câmara desde 1968. A votação contou com um racha do partido governo - 10 de seus deputados votaram com a oposição na questão -, que já contava com uma pequena e pouco confiável maioria na Câmara, e as oposições lograram assim rejeitar a medida.

${ }^{132}$ O Pacote se transforma na Lei 6978/1982 e sua íntegra se encontra no site http://www.planalto.gov.br/ccivil_03/leis/1980-1988/L6978.htm

133 A oposição (sobretudo o PMDB) há muito tentava evitar que novos casuísmos pudessem afetar as eleições de 1982 em favor do governo. O senador Itamar Franco (PMDB/MG) apresenta em 1981 uma proposta de lei complementar impedindo qualquer modificação na legislação eleitoral pelo menos um ano antes das eleições. Infelizmente, para as oposições, a proposta foi arquivada.

${ }^{134}$ Múltiplas fontes foram usadas para a análise do impacto do "Pacote de Novembro" sobre os partidos naquele momento: Folha de S. Paulo -26/11/1981, O Estado de S. Paulo-26/11/1981, Revista Veja, 
bancada do PDS fechasse questão em torno dessas e também de outras medidas que já tramitavam no Congresso naquele momento ${ }^{135}$, garantindo dessa forma a sua aprovação.

A primeira das propostas, a vinculação do voto em todos os níveis (fato que encerraria os impasses quanto ao desdobramento do pleito em dois dias), amparava-se na ideia de que o eleitor iria orientar seu voto primeiramente de acordo com os candidatos de seu município, para os cargos de prefeito e vereador, e a partir deles reproduziria o voto no mesmo partido nos outros níveis. O governo deixava clara, dessa maneira, sua confiança nas bases organizacionais municipais de seu partido, sobretudo nos Estados do Norte e do Nordeste, para manter a sua representação majoritária no Congresso. A ideia de uma "municipalização das eleições" tinha respaldo no resultado das eleições municipais anteriores, de 1976, quando o partido do governo tinha sido o grande vencedor: a Arena havia ganho 3.176 prefeituras e elegido 27.120 vereadores, frente aos 614 prefeitos e 9.486 vereadores eleitos pelo MDB (Lamounier, 1990, e TSE, Dados estatísticos, vol. 12,1988$)^{136}$.

A segunda medida, que tornava obrigatória a apresentação de candidatos em todos os níveis, na prática proibia as coligações, um ponto ainda obscuro na legislação eleitoral até aquele momento. Essa mudança forçava os partidos oposicionistas a brigar entre si pelos votos do eleitorado, mesmo que se não o quisessem. Caso houvesse a possibilidade de coligações, as oposições poderiam traçar uma linha demarcatória mais clara para o eleitorado, para situar quais partidos realmente estavam no lado da oposição ao governo e quais representavam o papel de "oposição confiável"

Edição n. 691, 2/12/1981 e Coluna Castello Branco publicadas no Jornal do Brasil nos dias 26,27 e 28/11/1981.

${ }^{135}$ Caso o partido aprovasse o "Fechamento de questão" em seu Diretório Nacional, o parlamentar que votasse contra a orientação do governo poderia perder o seu mandato. A medida visava também a aprovação de outras medidas casuísticas já em tramitação, como, por exemplo, a criação do Estado de Rondônia.

${ }^{136}$ Para uma análise das eleições de 1976, ver Reis (1978b). 
para o Regime. A medida também prejudicava diretamente os partidos menores, que devido a ela teriam dificuldades para apresentar candidatos em alguns estados onde já haviam iniciado diálogos visando possíveis coligações ${ }^{137}$.

Após o anúncio do Pacote, a primeira reação pública dos partidos de oposição foi uma nota elaborada por parte das bancadas da oposição no Senado, órgão que havia sido fonte dos primeiros entendimentos visando à fusão das oposições meses antes. No documento, repudiam a decisão do governo pela suspensão das negociações que vinham em curso e apontam a fusão de todas as oposições como uma solução possível ${ }^{138}$. No fim do mesmo dia em que a nota fora emitida, PMDB, PP e PDT também emitem notas oficiais repudiando a ação do governo e anunciam que irão se reunir e convocar as lideranças dos outros partidos para discutir a proposta de fusão das oposições, em resposta à tentativa do governo de manter as oposições divididas sem que fosse dada a possibilidade de se coligarem.

Porém, apesar dessa reação inicial, a tese de fusão total das oposições em torno de um só partido, algo como um "novo MDB", se estende por pouco tempo. Através de uma consulta a dois juristas (Arnaldo Malheiros e Marcos Heusi), os partidos avaliam que a tese de fusão representava um longo caminho a ser percorrido e que se concluiria apenas meses antes do pleito, em meados de 1982. Ao mesmo tempo, novas medidas propostas pelo Regime contribuíam para que os pequenos partidos se afastassem da proposta de união das oposições ${ }^{139}$. A principal delas seria o

${ }^{137}$ O Pacote tinha também um impacto de longo prazo mais profundo, mas que não será analisado aqui por estar além dos objetivos desta pesquisa. Caso se confirmassem as previsões de crescimento das oposições naquelas eleições, o governo corria o risco de perder o controle do Colégio Eleitoral de 1985, que iria eleger o sucessor do Presidente Figueiredo. Dessa forma, o conjunto de "novos casuísmos" poderia beneficiar o partido governista em seu desempenho eleitoral, fazendo com que a composição do futuro Colégio fosse melhor para o Regime.

${ }_{138} \mathrm{O}$ texto da nota em sua íntegra se encontra no ANEXO 5.

${ }^{139}$ Alguns partidos desde o princípio mantinham uma posição reticente quanto à fusão total, como era o caso de PT e PDT, e as novas medidas representam a gota d'água para que eles se afastem do processo de fusão. Líderes dos dois partidos descartavam o uso da fusão como uma "ação política de curto prazo", que visava apenas as eleições de 1982, e tomavam como posição o fortalecimento do seu próprio partido para 
adiamento para as eleições de 1986 das exigências mínimas de apoio eleitoral que os partidos deveriam obter, fazendo com que os pequenos partidos pudessem descartar a fusão e procurar se regulamentar definitivamente apenas em 1986.

Conforme a hipótese de uma fusão total das oposições passa a se mostrar inviável, a possibilidade de uma fusão apenas entre PP e PMDB passa a ganhar força rapidamente, no mês de dezembro de 1981, transformando-se em uma proposta de “incorporação" do primeiro ao segundo ao invés de uma "fusão" por conta do prazo mais curto para ser implementada ${ }^{140}$. A proposta foi, de fato, feita pela cúpula de ambos partidos, mas não havia unanimidade em suas bases a respeito dessa solução.

No que tange o nível regional dos dois partidos, alguns diretórios se mostravam inteiramente contra o processo de incorporação feito através de acordo entre as cúpulas.

Como exemplo temos o caso do diretório paulista do PP, que não aceitava a proposta, alegando que já estava em campanha para a candidatura de Olavo Setúbal ao governo do estado e que contava com uma rede organizativa ampla o suficiente para ultrapassar a barreira mínima de votos necessária para se manter existindo. Da mesma maneira, o diretório fluminense do PMDB, que contava com uma forte ala ligada ao MR-8, não aceitava compartilhar da mesma sigla que a "máquina chaguista" do PP e que seria incorporada a partido naquele Estado. De fato, a bancada federal peemedebista do

diferenciarem-se das outras agremiações partidárias de oposição e visar disputas eleitorais futuras. Já com relação ao PTB, que havia acabado de incorporar mais uma vez em seus quadros o ex-presidente Jânio Quadros, a proposta de fusão com os outros partidos seria muito difícil pelo recente veto de filiação que o PMDB havia aplicado ao político. Ademais, uma outra medida aprovada pelo Regime afastou de vez os três pequenos partidos da proposta de fusão. Através dela, estipulava-se que nos municípios onde os partidos não estivessem organizados, o eleitor poderia votar apenas nos cargos estaduais e federais. A medida beneficiou diretamente os partidos pequenos (PTB, PDT e PT), que contavam com uma rede organizativa menor.

${ }^{140}$ A literatura a respeito dos partidos políticos brasileiros que cita esse processo não distingue os termos "fusão" e "incorporação", sendo o primeiro o mais usado e de maneira errônea, ao considerarmos que os dois processos exigem medidas e resultados totalmente distintos. Enquanto a incorporação mantem a existência de uma das siglas, a fusão obrigava a criação de um novo partido político, com uma nova sigla partidária. 
Rio de Janeiro se reúne e emite uma nota pública, declarando-se unanimemente contrária à incorporação.

Apesar das discordâncias regionais, a proposta de incorporação ganha rapidamente a simpatia das cúpulas de ambos partidos, que decidem levar adiante o processo. Ela é analisada tanto pela Direção do PMDB, em sua $2^{a}$ Convenção Nacional, nos dias 5 e 6 de dezembro de 1981, quanto pelo PP, em reunião da sua Comissão Executiva Nacional em conjunto com os presidentes dos Diretórios Regionais, no dia 10 de dezembro do mesmo ano ${ }^{141}$. Como resultado dessas reuniões e segundo suas avaliações internas, PP e PMDB decidem iniciar o processo de incorporação, seguindo os passos apontados pelos juristas consultados, supracitados. A próxima medida seria convocar seus partidos a realizar na mesma data suas respectivas Convenções Nacionais, com o intuito de homologar o processo.

Quando da realização das Convenções, no dia 20 de dezembro, tornaram-se evidentes os focos de contrariedade ao processo naqueles que seriam os Estados nos quais seria mais difícil uma nova acomodação das elites locais, desta vez sob a mesma sigla partidária. O acordo estipulado entre os partidos definia que a composição do Diretório Nacional do "novo PMDB" deveria ser proporcional à representação de ambos os partidos em nível federal, e que o mesmo critério seria aplicado aos Diretórios Regionais de acordo com suas representações em cada Assembleia Estadual. Esse acordo serviu para apaziguar os interesses dos dois partidos em certos Estados mas os entraves ao processo (políticos e ideológicos) se mantiveram em debate, sobretudo naqueles estados onde o PP era mais forte que o PMDB, tendo consequências futuras para a distribuição de forças no interior do PMDB (como veremos na seção 4).

\footnotetext{
${ }^{141} \mathrm{Na}$ reunião do PP, os líderes do partido emitem uma nota pública anunciando que levarão adiante a discussão em torno da proposta de incorporação. A nota em sua íntegra se encontra reproduzida no Anexo 6.
} 
Ao final das Convenções a proposta de incorporação é finalmente aprovada por ambos os partidos em nível nacional. Na Convenção do Partido Popular, na qual eram necessários 156 votos favoráveis à proposta (número que representava a maioria absoluta de 311 votos dos convencionais, com a ressalva de que alguns políticos teriam o direito a mais de um voto), o resultado da votação é de 162 votos a favor e 96 contra. O resultado explicitou as divergências que existiam no partido com relação à proposta, com divisões na votação dos convencionais de alguns Estados, sobretudo na bancada de Minas Gerais. Já na Convenção do PMDB, dos 503 votos possíveis, a proposta deveria obter a metade dos votos daqueles presentes e assim o fez, alcançando 331 votos a favor e 41 contra. Os convencionais peemedebistas fluminenses reafirmaram sua posição e todos votaram contrariamente à proposta (entre eles o deputado federal Paulo Rattes, $1^{\circ}$ Secretário do partido), assim como alguns representantes da Paraíba ${ }^{142}$.

No dia 14 de fevereiro de 1982, PP e PMDB realizaram enfim uma Convenção Nacional Conjunta, que contava com os membros de ambos partidos. Seu objetivo era referendar a incorporação do primeiro ao segundo e definir a nova composição do Diretório Nacional e da Executiva do PMDB. Ao mesmo tempo, inicia-se um processo de defecções por parte daqueles políticos que se colocaram contra a incorporação (beneficiados com a reabertura do prazo de filiação partidária), movimento esse que acabaria gerando espólios para o partido do governo. A votação da Convenção foi expressiva: dos 673 presentes, a proposta recebeu 635 votos favoráveis ${ }^{143}$. Na mesma ocasião foram eleitos os novos membros do Diretório Nacional, que seria composto por 69 membros (46 peemedebistas e 23 ex-pepistas), e da Executiva Nacional do "novo PMDB”, que iria dirigir o partido até dezembro de 1983, sendo

\footnotetext{
${ }^{142}$ Folha de S. Paulo, 21/12/1981, p. 4

${ }^{143}$ Revista Veja, edição 703, 24 fev. 1982, p.20-22.
} 
distribuídos os cargos entre os dois partidos ${ }^{144}$. Na ocasião, a nova composição da Comissão Executiva Nacional passa a ter 9 membros que já eram pemedebistas e 4 ex-pepistas, com a seguinte composição:

Presidente: Ulysses Guimarães

$1^{\circ}$ Vice-presidente: Tancredo Neves

$2^{\circ}$ Vice-presidente: Miguel Arraes

$3^{\circ}$ Vice-presidente: Pedro Simon

Secretário-geral: Francisco Pinto

$1^{\circ}$ Secretário: Miro Teixeira

$2^{\circ}$ Secretário: Euclides Scalco

Tesoureiro Geral: Mauro Benevides

$2^{\circ}$ Tesoureiro: Tarcísio Delgado

Vogais: Mendes Canale, Aloisio Alves, Teotônio Vilela e Paulo Rattes

Suplentes: Fernando Cunha, Nabor Junior, Chagas Rodrigues, Mário Moreira, João Linhares, Renato Archer e João Menezes

Fonte: Processo 6.371 - Resolução/TSE n 11.192

Restava apenas aguardar pelo reconhecimento e homologação do Tribunal Superior Eleitoral. Finalmente, apesar das inúmeras manobras do governo e de pepistas e peemedebistas descontentes com a incorporação ${ }^{145}$, no dia 2 de março o Tribunal Superior Eleitoral aprovou o processo, por 4 votos a 2. Estava dado o último passo para o processo de incorporação nacional de um partido ao

\footnotetext{
${ }^{144}$ A nova composição do Diretório Nacional do PMDB será analisada no tópico seguinte e a lista com os diretores se encontra no ANEXO 7, reproduzida da Resolução Processo 6.371 - Resolução/TSE n ${ }^{\circ}$ 11.192 .

${ }^{145}$ A primeira manobra já se deu quando ainda ocorriam as primeiras reuniões entre representantes dos partidos para estudar a proposta de incorporação, sendo um projeto de lei do Deputado Jorge Arbage (PDS/PA), proibindo fusões e incorporações entre partidos que tivessem menos de 3 anos de existência. Posteriormente, há também resistências entre os próprios pepistas: no Rio Grande do Sul (sob a liderança do Secretário Geral desta Executiva, o ex-porta voz da linha dura do Regime, Clóvis Stenzel) e em São Paulo, os descontentes divulgam à imprensa seus "Manifestos" contrários à incorporação. Entre os peemedebistas, presidentes do partido de algumas zonas eleitorais do RJ também enviam pedidos de impugnação da incorporação ao TSE.
} 
outro. Extinguia-se uma efêmera experiência partidária de nossa história política. Uma vez incorporado o PP ao PMDB, enterrava-se também o projeto de Golbery e Petrônio Portella, de criação de um partido que ocupasse o centro do espectro partidário e que pudesse se coligar com o partido governista.

Ao mesmo tempo, surgia naquele momento um novo PMDB, o "PPMDB", com uma nova composição interna e ainda maior do que fora o extinto MDB, contando com 29 senadores, 181 deputados e 1 governador de Estado, o governador do Rio de Janeiro, Chagas Freitas. O "Pacote" editado meses antes com o intuito de beneficiar o Regime e o seu partido de sustentação acabaria também por prejudicá-los, ao acarretar a união dos dois principais partidos de oposição e manter a proposta de pluripartidarismo editada em 1979. Como assinalou Linz (1978, citado em Melhem 1998, p. 76), os fatos nem sempre caminham em conformidade com a engenharia política que os engendra.

$\mathrm{Na}$ próxima e última seção deste capítulo, analisamos as consequências internas do processo de incorporação para o PMDB. Utilizamos como indicadores empíricos a nova composição do seu Diretório Nacional e de sua Executiva Nacional, além de apresentar alguns elementos da formação do novo PMDB em alguns estados.

\section{Surge um novo PMDB, o "PPMDB"}

A incorporação do PP foi um evento inesperado para o Regime Militar, que procurava a todo custo manter o controle do processo de abertura "lenta, segura e gradual". Com a proibição das coligações, efeito implícito do Pacote de Novembro, gerou-se uma coligação permanente entre os dois maiores adversários eleitorais do Regime. Porém, após a homologação da incorporação, alguns efeitos colaterais fizeram com que o governo tolerasse essa união (como os “espólios” gerados para o partido governista) ${ }^{146}$. Não está

\footnotetext{
${ }^{146}$ Contando com uma minoria escassa na Câmara dos Deputados, o governo reabre o prazo de filiação partidária após a extinção do PP e se beneficia com a migração dos deputados descontentes com a
} 
entre os objetivos desta pesquisa fazer uma análise sobre quais motivos levaram a incorporação do PP ao PMDB, ou o porquê do Regime Militar aceitar esse acontecimento. Partiremos do princípio que a incorporação é um fato histórico consumado, e cabe-nos apenas apontar que os poucos estudos que citam o processo de incorporação julgam que ela se deu em decorrência das dificuldades colocadas pelo governo para a participação do PP nas eleições de 1982 (Kinzo, 1988, p. 212; Kinzo, 1989, p. 9; Kinzo, 1993, p. 39; Delgado, 2006, p. 210; Ferreira, 2001, p. 156; Ferreira, 2006, p. 193; Melhem, 1998, p. 262). O Partido Popular teria, de acordo com esses estudos, dificuldades em apresentar candidatos para todos os cargos e vencer a barreira do voto vinculado em seu primeiro teste eleitoral (Segrillo, 2005, p. 123; Melhem, 1998, p. 81), sendo, assim, inviável eleitoralmente. Algumas evidências indicam que esses argumentos podem ser relativizados ${ }^{147}$ e que novas interpretações sobre esse processo poderiam surgir ${ }^{148}$, mas investigá-los não é um dos objetivos desta pesquisa. Nosso objetivo é evidenciar as consequências do processo de incorporação para a composição interna do PMDB, um aspecto nunca explorado pela literatura sobre o partido.

incorporação. A representação do partido governista na Câmara foi de 214 para 221, assegurando a maioria para o governo durante o ano de 1982. Além disso, lideranças importantes que estavam no PP migraram nos meses seguintes para o partido governista. Foi o caso dos deputados Thales Ramalho (PP/PE, que classificava a incorporação como "uma estupidez" - Revista Veja, edição 694, 23 dez. 1981, p.23) e Herbert Levy (PP/SP, que argumentava que "a ausência de um partido como o PP representa um mal para a efetiva consolidação democrática do país" Folha de S. Paulo, 4/2/1981, p.1), assim como de Magalhães Pinto, Paulo Egídio e Claudio Lembo. Outro fato que pode ter levado o governo a aceitar a incorporação foi a recusa dos pequenos partidos a participar do processo. A sinalização do governo de que haveriam mudanças nas exigências percentuais de votos para a legalização dos partidos, mais um dos casuísmos do governo, serviu como estímulo para afastar as pequenas siglas da tese de "fusão total" das oposições . Dessa forma, manteve-se o pluripartidarismo que era tão anunciado pelo Palácio com as reformas promovidas em 1979 e 1981 e o governo conseguia assim manter as oposições ainda divididas, evitando que surgisse um "novo MDB".

${ }^{147}$ Como, por exemplo, o fato dos dois partidos possuírem as maiores redes de diretórios da oposição e assim terem as maiores chances de superar as exigências legais impostas pela legislação para as eleições de 1982. Ou também o fato de que muitos candidatos do PP já vinham liderando as pesquisas eleitorais em alguns estados, como no Amazonas, com Gilberto Mestrinho, ou em Minas Gerais, com Tancredo Neves.

${ }^{148}$ A incorporação representou também uma ação concreta das oposições frente aos casuísmos do governo, num contexto onde o pragmatismo eleitoral dos dois partidos pode ter superado as suas divergências ideológicas. 
Apenas três autores apontaram que podem ter havido consequências para o PMDB por conta da incorporação, mas nenhum deles procurou apresentar evidências para comprovar seus argumentos. Segundo Soares (1984, p. 111), a incorporação do PP trouxe para o PMDB fragmentos de uma importante rede organizacional a nível municipal ${ }^{149}$ e um número nada desprezível de votos de classe média e da elite, principalmente rurais e de pequenas cidades, antes vinculados à Arena, e que passaram ao PMDB por meio do PP. Por sua vez, Power (1997, p.77) apontou que o partido viu ser acrescida à sua composição interna uma pequena ala conservadora após a incorporação. E, por fim, Benevides (1986), para quem naquele momento teve início o processo de "deformação mórbida" (do PMDB), devido à assimilação do PP, ironicamente apelidado "partido dos patrões", ou "partido clandestino da burguesia". Nosso objetivo nesta pesquisa será especificamente demonstrar parte das transformações que foram apontadas por esses autores, especificamente as que dizem respeito à composição interna do PMDB.

Para parte da opinião pública da época, a incorporação representou apenas o retorno de alguns correligionários ao seio de seu antigo partido e não gerou tanta repercussão. Porém, a incorporação foi um processo que vai para além disso e há depoimentos de políticos peemedebistas da época que expressam essa perspectiva.

Para Renato Archer, um dos Fundadores do PMDB:

"A dissidência do PP foi importante e chegou a confundir a opinião pública, porque um pedaço dela saiu do MDB, com pessoas que lutaram contra a ditadura. Mas ao PP aderiu imediatamente uma fatia grande da Arena, que queria se desmarcar do estigma de

\footnotetext{
${ }^{149}$ Segundo reportagens do jornal Folha de S. Paulo - 18/04/1982, p.6 e 06/05/1982, p. 6- e declarações de seus partidários o PMDB passaria de 2064 diretórios pré-incorporação para mais de 3 mil diretórios municipais.
} 
ter apoiado a revolução. Mas o PP resultou inviável, fundiu-se ao PMDB e trouxe no seu bojo (como uma espécie de "presente de grego", de cavalo de Tróia) uma descaracterização deste como um partido exclusivamente composto por pessoas que combateram a ditadura. Muitos dos que vieram do PP junto com o Tancredo eram altamente comprometidos com os acontecimentos do período autoritário" (Melhem e Russo, 2004, p. 404) ${ }^{150}$.

Para Maria da Conceição Tavares, importante quadro intelectual do PMDB:

“(o comando da Executiva) mudou depois que o PMDB incorporou o PP, depois que chegou o Tancredo. O grupo do Ulysses era o chamado Travessia, ao qual pertencíamos (Maria da Conceição Tavares), que se situava mais à esquerda, e o do Tancredo era o grupo que veio do PP, que não me lembro mais como se chamava. Todos fomos convocados para a incorporação, porque havia resistências, gente que não queria. (...) Depois da fusão a executiva do PMDB passou a ter sete membros do Grupo Travessia e sete que o Dr. Tancredo indicara. Neste grupo tinha políticos duros como o Roberto Cardoso Alves, mas também tinha uma banda progressista." (Melhem e Russo, 2004,p. 258-259). ${ }^{151}$

Segundo Bresser-Pereira (1984), que viria a ser Secretário do governo de São Paulo durante a primeira administração peemedebista, a incorporação do PP levou o PMDB para a direita, pois o PP era o partido de centro-direita que representava o pensamento do empresariado progressista, mas conservador no Brasil, enquanto o PMDB, não obstante sua imensa variedade, era o

\footnotetext{
${ }^{150}$ Entrevista concedida às autoras em 19/07/1993

${ }^{151}$ Entrevista concedida às autoras em 1993.
} 
partido de centro-esquerda, o partido dos trabalhadores, das classes médias assalariadas e de uma parte da pequena e média burguesia. Para ele, a incorporação do PP não chegou a desfigurar o PMDB, mas o fez perder um pouco de sua identidade com os trabalhadores. Ainda segundo Bresser-Pereira:

“Tancredo tinha criado o PP exatamente quando o MDB se tornou PMDB, para construir um partido mais ao centro. Depois teve a visão de acabar com o PP e retornar ao PMDB e, ao fazê-lo, acabou ocupando a ala mais à direita dentro deste partido, com a qual os empresários naturalmente se identificavam mais." (Melhem e Russo, 2004, p. 212).

Para Fernando Henrique Cardoso, suplente de Senador e também um importante quadro intelectual do partido:

“A nau pepista encalhou no "pacotão" eleitoral e não teve outro jeito senão buscar o calado de uma aliança com o PMDB. Formou-se, de novo, a frente eleitoral contra o governo." (Folha de S. Paulo, 18/02/1982, p. 2)

Como visto nos depoimentos citados, o espaço ocupado por essa nova ala de políticos, que a partir de então ingressaram no PMDB, alterou a composição interna do partido. Se até o final de 1981 o partido apresentava uma composição interna mais homogênea, devido à saída de "moderados" e "adesistas" que passaram ao PP e PDS, a partir da incorporação cresce o setor "moderado" no PMDB e engrossam-se as fileiras de políticos ex-arenistas.

Em seu novo Diretório Nacional, eleito após a Convenção Nacional Conjunta que homologou a incorporação, os pepistas tiveram direito a um terço de sua composição total: 23 postos de um total de 69 membros. Ou seja, são 23 novos políticos moderados que passam a compor o Diretório Nacional do PMDB; políticos que 
pouco tempo antes participavam de um partido que estava à direita desse partido, e que buscavam ocupar o centro do espectro partidário. Desses 23 ex-pepistas, pelo menos 10 (23\%) tiveram alguma vinculação com a Arena durante o Regime Militar. Ou seja, a partir daquele momento, o PMDB passaria a ter menos membros ex-emedebistas em seu Diretório Nacional e passaria a ter 16 exarenistas, que engrossam as fileiras do seu campo moderado e que passam a disputar o perfil ideológico do partido com suas outras alas, sobretudo a que se identificava como "Tendência Popular". Ironicamente, a partir daquele momento, os herdeiros do MDB, que tanto havia lutado contra o Pacote de Abril em 1977, agora viam o PMDB ter em seu Diretório Nacional alguns dos senadores biônicos nomeados justamente através daquele Pacote.

Por sua vez, a composição da Executiva Nacional representava um equilíbrio entre os setores moderados, que ocupavam novos espaços, e a "Tendência", evidenciando a transformação pela qual o partido havia passado com a incorporação. A $1^{\text {a }}$ Vice-presidência e a $1^{\text {a }}$ Secretaria foram entregues a políticos moderados, respectivamente Tancredo Neves e Miro Teixeira, mas a ala à esquerda do partido logrou manter Miguel Arraes na $2^{a}$ Vicepresidência e Francisco Pinto, um de seus mais aguerridos representantes, passava a ser o Secretário Geral do Partido ${ }^{152}$. Entre os vogais, dois novos membros ex-arenistas substituiriam dois integrantes do grupo "autêntico" na Executiva. Entravam o Senador Mendes Canale e o ex-governador do Rio Grande do Norte Aloisio Alves, e saíam Alencar Furtado e Fernando Cunha.

Tabela 8. Comparação entre a filiação partidária prévia dos componentes do Diretório Nacional do PMDB eleitos na primeira Convenção Nacional e após a Convenção que aceitou a incorporação do PP

\footnotetext{
${ }^{152}$ Uma escolha vista com apreensão por parte do governo, que acredita que o PMDB optou por uma
} linha mais "radicalizante" na sua nova composição - Folha de S. Paulo 18/02/1982, p. 1 


\begin{tabular}{lcc|cc}
\hline & $\mathrm{N}$ & \% do total & $\mathrm{N}$ & \% do total \\
\hline MDB & 61 & $88,4 \%$ & 53 & $76,8 \%$ \\
\hline Arena & 8 & $11,6 \%$ & 16 & $23,2 \%$ \\
\hline $\begin{array}{l}\text { Diretório } \\
\text { Nacional }\end{array}$ & 69 & $100 \%$ & 69 & $100 \%$ \\
\hline
\end{tabular}

Fontes: elaboração própria a partir de informações coletadas do Centro de Pesquisa e Documentação de História Contemporânea do Brasil (CPDoC/FGV) e do Acervo do TSE

Com relação à sua representação legislativa, o PMDB viu suas bancadas aumentarem com a incorporação do PP, mas em um processo que em seu bojo trouxe para o PMDB uma camada de políticos que pertencia à ala "moderada" do antigo MDB, além de um setor de ex-arenistas que quase não se fazia presente no partido até então. A representação legislativa do PMDB será tratada em mais detalhes no próximo capítulo; até lá a Tabela 12 permitirá visualizar o quanto a bancada do partido aumentou após aquele processo. Foi neste momento que teve início o processo de "inchaço" das fileiras do PMDB (a entrada de quadros não comprometidos com o seu programa), que muitos autores atribuem apenas ao período da sua chegada ao governo federal, em 1985, ou ao resultado das eleições de 1986 (Couto,1997, p.35; Sadek, 1989a, p.67; Sadek, 1989b, p.113; Bresser Pereira, 1993, p.240; Lamounier, 1989, p.52; Power, 1997, p.77).

Tabela 9. Distribuição partidária no Congresso antes e após a Incorporação do PP ao PMDB

\begin{tabular}{|c|c|c|c|c|c|c|}
\hline & \multicolumn{3}{|c|}{ Pré-incorporação } & \multicolumn{3}{|c|}{ Pós-incorporação } \\
\hline & Câmara & Senado & Congresso & Câmara & Senado & Congresso \\
\hline PDS & 214 & 37 & 248 & 221 & 36 & 257 \\
\hline PMDB & 121 & 22 & 144 & 180 & 29 & 209 \\
\hline P P & 67 & 8 & 76 & - & - & - \\
\hline PDT & 9 & & 9 & 9 & & 9 \\
\hline $\mathbf{P T}$ & 5 & & 5 & 5 & 1 & 6 \\
\hline РTB & 4 & & 4 & 5 & & 5 \\
\hline $\begin{array}{l}\text { Sem } \\
\text { Partido }\end{array}$ & & & & & 1 & 1 \\
\hline Total & 420 & 67 & & 420 & 67 & \\
\hline
\end{tabular}


Fontes: Folha de S. Paulo, 17/11/1981, p. 4, 3/01/1982, p.8, e 6/03/1982, p.

Como dito anteriormente, o processo de incorporação também acabou por ter consequências para o PMDB que aumentaram a sua heterogeneidade regional. Esse fenômeno contribuiu para um processo de “desfiguração nacional” do partido logo em seus primeiros anos, fazendo com que o PMDB tivesse um caráter diferente em cada Estado, a depender da maneira como se houvesse dado a incorporação no nível local. Enquanto em alguns estados o PMDB não teve de incorporar o PP, dada a inexistência deste último (como foram o caso de Goiás, Alagoas e Rondônia), em outros ocorreram processos específicos de acomodação das elites locais. Alguns casos ilustrativos e que podem nos servir como exemplo desse processo, numa perspectiva comparativa, são o do Rio de Janeiro, de Minas Gerais, de São Paulo e da Paraíba.

No Rio de Janeiro, o PMDB pré-incorporação era menor que o PP e apresentava uma forte ala de esquerda, com políticos claramente identificados com o MR-8 e o PCdoB. Após a incorporação, a "máquina chaguista" e o seu principal expoente, o governador nomeado Chagas Freitas, ingressam no PMDB, que naquele estado, especificamente, havia adotado um critério de paridade na divisão dos cargos entre ex-pepistas e peemedebistas. Com isso, apesar de trazer para si uma importante rede organizacional naquele Estado, o PMDB pagou um preço: importantes figuras e lideranças políticas evadem à sigla ${ }^{153}$ (entre eles o Senador Saturnino Braga, pré-candidato ao governo do Estado, que acaba por perder espaço para a ala chaguista, e

\footnotetext{
${ }^{153}$ Enquanto o MDB possuía quatro senadores no Rio de Janeiro no período pré-reforma partidária, o PMDB não possui qualquer senador. Amaral Peixoto se transferiu ao PDS logo após a reforma, enquanto que Saturnino Braga passa ao PDT, e Hugo Ramos e Nelson Carneiro para o PTB, todos descontentes com o processo de incorporação do PP naquele estado.
} 
posteriormente ingressa no PDT de Brizola para concorrer a uma vaga ao Senado $)^{154}$.

Essa nova feição "governista" e conservadora do PMDB no Estado, que agora teria como presidente regional o ex-pepista Miro Teixeira, gera-lhe consequências de médio prazo no pleito de $1982^{155}$.

O eleitorado tradicionalmente oposicionista do Rio de Janeiro acaba por repelir o novo perfil do PMDB, que vinha construindo uma candidatura oposicionista e que a partir de então passava a construir uma candidatura de continuidade governista.

Ao mesmo tempo, as candidaturas de Sandra Cavalcanti (PTB) e Emílio Ibrahim (PDS), que foram identificados com a Arena em um momento de sua historia política anterior à reformulação partidária, também passam a declinar. Assim, abriu-se espaço para a vitória de Brizola, que se encontrava em terceiro nas pesquisas e arranca para a vitória no governo do estado, mostrando-se como o único candidato "verdadeiramente oposicionista" perante o eleitorado.

Fenômeno semelhante ocorreu com o PMDB Mineiro, que acabou por ser "incorporado ao PP"156, mas que, diferentemente do caso fluminense, ainda se sagra vitorioso na eleição para governador em 1982. O Partido Popular possuía, quando de sua incorporação, 18 deputados estaduais e mais de 600 diretórios, encontrando-se à frente do PMDB, que possuía 8 cadeiras e 265 diretórios ${ }^{157}$. Após a incorporação, a nova composição do Diretório

\footnotetext{
${ }^{154}$ Outros políticos que deixaram o PMDB naquele estado após a incorporação foram os Deputados Florim Coutinho, José Maria de Carvalho, Felipe Pena, Edson Khair e Délio dos Santos e o Senador Nelson Carneiro.

${ }^{155}$ Em relação à história política do Rio de Janeiro nesse período, ver Ferreira (2006) e Alkmin (2014). Com referência ao "chaguismo", ver Diniz, op. Cit. e Sarmento (2002) e para um estudo de caso a respeito do "chaguismo" em nível municipal, ver Cantalejo (2008).

${ }^{156} \mathrm{Na}$ seção regional do Rio Grande do Norte do PMDB parece ter ocorrido um processo que se assemelha aos casos mineiro e fluminense, com o PP "incorporando" o PMDB, que possuía uma certa ala de esquerda, mas que ao final tem sua candidatura ao governo do estado derrotada pelo PDS.

${ }^{157}$ Para uma análise específica da história política mineira no período de transição, ver The traditional political elite and the transition do democracy, em Hagopian (1996, capítulo 7).
} 
Regional do PMDB no Estado passa a contar com mais ex-pepistas do que peemedebistas. Nos meses seguintes, as duas alas que passam a formar o partido naquele estado começam a disputar espaço na política estadual, fazendo emergir tensões entre o grupo peemedebista pré-incorporação (liderado principalmente por Itamar Franco, que já era pré-candidato ao governo do Estado) e o novo grupo pepista (encabeçado por Tancredo Neves). O grupo liderado pelos ex-pepistas acaba por vencer a disputa e ganha a indicação do candidato a governo do Estado. Enfim, o $1^{\circ}$ Vice-presidente do "novo PMDB" torna-se o candidato do partido ao governo estadual e indica como vice Hélio Garcia, deputado eleito pela Arena anos antes, e os dois acabam por ser eleitos.

Por sua vez, no Estado de São Paulo, a incorporação não chega efetivamente a "mudar o caráter" do PMDB por uma série de motivos. Em primeiro lugar, a pouca expressividade (em comparação à obtida em outros estados) do PP local. Em segundo lugar, pelo fato de o PMDB contar com uma parcela de militantes do campo da esquerda pouco representativa naquele estado (o PCB dentro do MDB paulista atuava mais na juventude do partido, segundo Melhem, 1998, p. 109), ao mesmo tempo que o partido era regionalmente disputado por duas fortes lideranças: Franco Montoro e Orestes Quércia (Melhem, 1998). O último motivo era o fato de que muitos dos pepistas contrários à incorporação se encontravam nesse Estado e parte deles opta por retirar-se da vida pública (como fora o caso de Olavo Setúbal) ou então ingressar no partido do governo (como o fizeram Claudio Lembo e Herbert Levy). Dessa forma, o PMDB herda boa parte da rede de diretórios do PP paulista sem ter que passar pelo mesmo processo de acomodação das elites que outros diretórios regionais tiveram que enfrentar ${ }^{158}$. O ex-pepista Caio Pompeu é o único membro do extinto partido que ingressa na Comissão Executiva Regional do

\footnotetext{
${ }^{158}$ Cabe apontar também que um número não muito significativo de diretórios municipais do extinto PP optou por se transferir para o PTB naquele estado.
} 
PMDB. Em uma perspectiva comparada, enquanto o "novo PMDB" do Rio de Janeiro apresentava um perfil ideológico claramente conservador, de continuidade do governo (que o faz perder as eleições naquele Estado), em São Paulo e em Minas Gerais o partido apresentava uma feição oposicionista e mais progressista do que naquele Estado, ainda que moderada por conta de suas principais lideranças.

A Paraíba representou também um caso bastante específico de acomodação das elites após o processo de incorporação, e que requer maiores estudos. Marcondes Gadelha, um dos líderes do PMDB naquele estado e ex-integrante do MDB Autêntico, migra para o PDS para não ter que partilhar o espaço do partido com os egressos do PP, que giravam em torno de Antônio Mariz, deputado eleito pela Arena e rival histórico na política daquele estado. Assim, pode-se dizer que na Paraíba, enquanto o PDS se "emedebiza" com o ingresso de uma liderança combativa, o PMDB se "areniza".

\section{Considerações finais}

De sua Fundação, no início de 1980, até o momento em que ocorre a incorporação do PP, em novembro de 1981, o PMDB conseguiu se manter com uma composição interna mais homogênea que o seu antecessor, o MDB. O partido havia conseguido se estruturar nacionalmente enquanto "partido político" e não mais como “frente política", colocando-se no sistema partidário à esquerda do PP e do PDS. Porém, após o processo de incorporação do PP, isso começou a mudar.

Como pudemos verificar através da composição dos seus principais órgãos de direção, o PMDB, a partir daquele momento, recebe um reforço em sua ala moderada. Retorna ao seio do partido a ala dos moderados que havia se transferido para o PP, reforçados pelo ingresso de um grupo de ex-arenistas. Dessa forma, o processo de incorporação acabou por afetar a homogeneidade interna que o 
PMDB havia mantido desde a passagem para o pluripartidarismo, em 1979, até o final de 1981. Surgia naquele momento um novo PMDB, com uma nova composição interna, o "PPMDB".

O processo de incorporação também gerou consequências importantes no sentido de uma desfiguração regional do partido. A depender do tamanho que PP e PMDB tinham em cada Estado no momento da incorporação, o "novo PMDB" surgiu mais forte, mas apresentando em cada Estado um perfil ideológico distinto. O processo de acomodação das elites políticas nos Estados que foram tratados na seção anterior assim nos demonstra.

O próximo passo a ser dado para analisarmos o impacto da incorporação para a composição interna do PMDB é analisar os resultados das eleições de 1982. Como vimos no primeiro capítulo, o PMDB desde sua fundação possuía uma forte base parlamentar no Congresso Nacional. Assim, a análise dos resultados de seu primeiro teste eleitoral para aquele mesmo locus nos permite perceber as diferenças na composição interna do partido antes e após o processo de incorporação. 


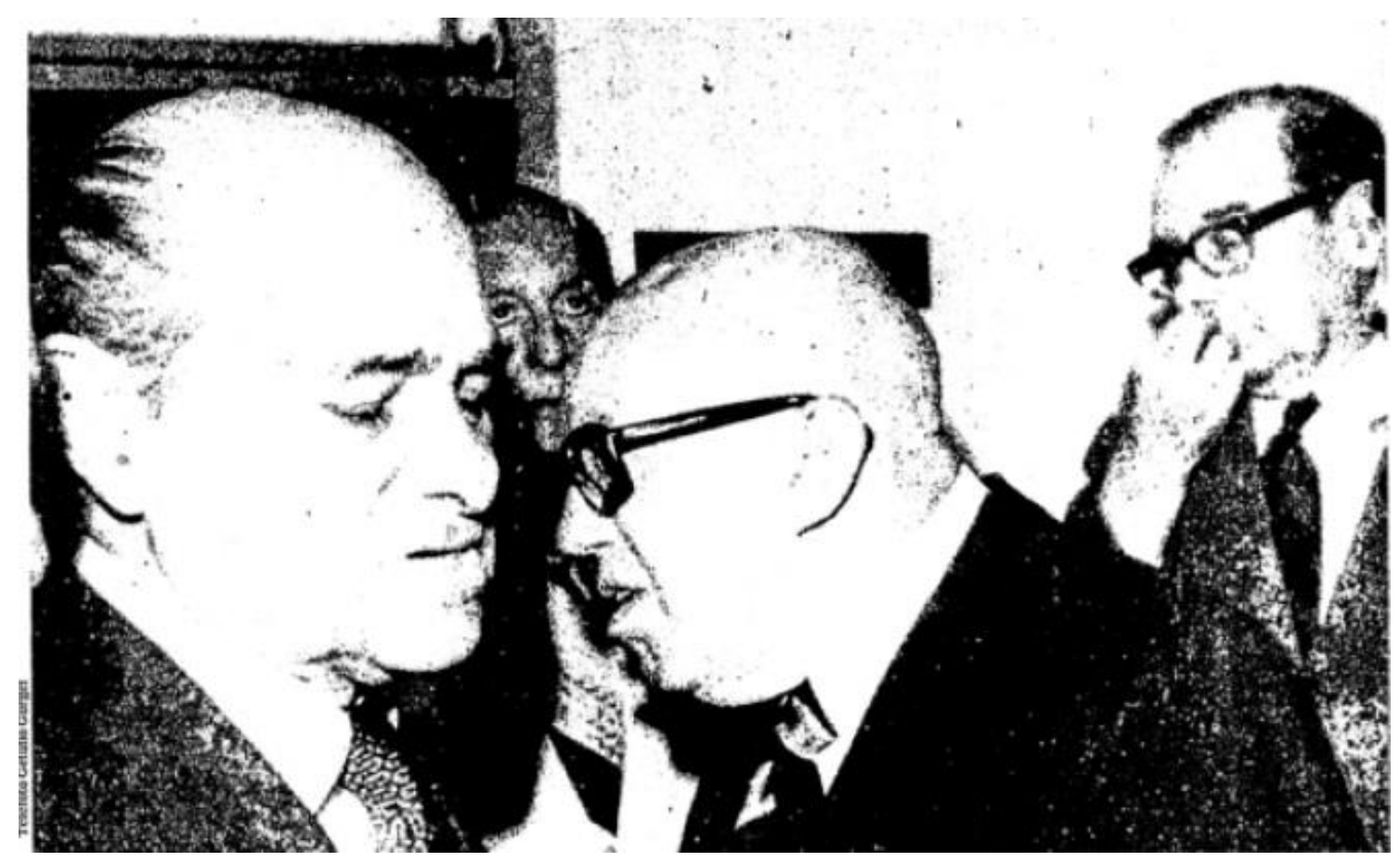

Tancredo Neves, Herbert Levy (ao fundo), Magalhães Pinto e Olavo Setúbal: alguns dos principais articuladores do Partido Popular. Folha de S. Paulo - 13/02/1980

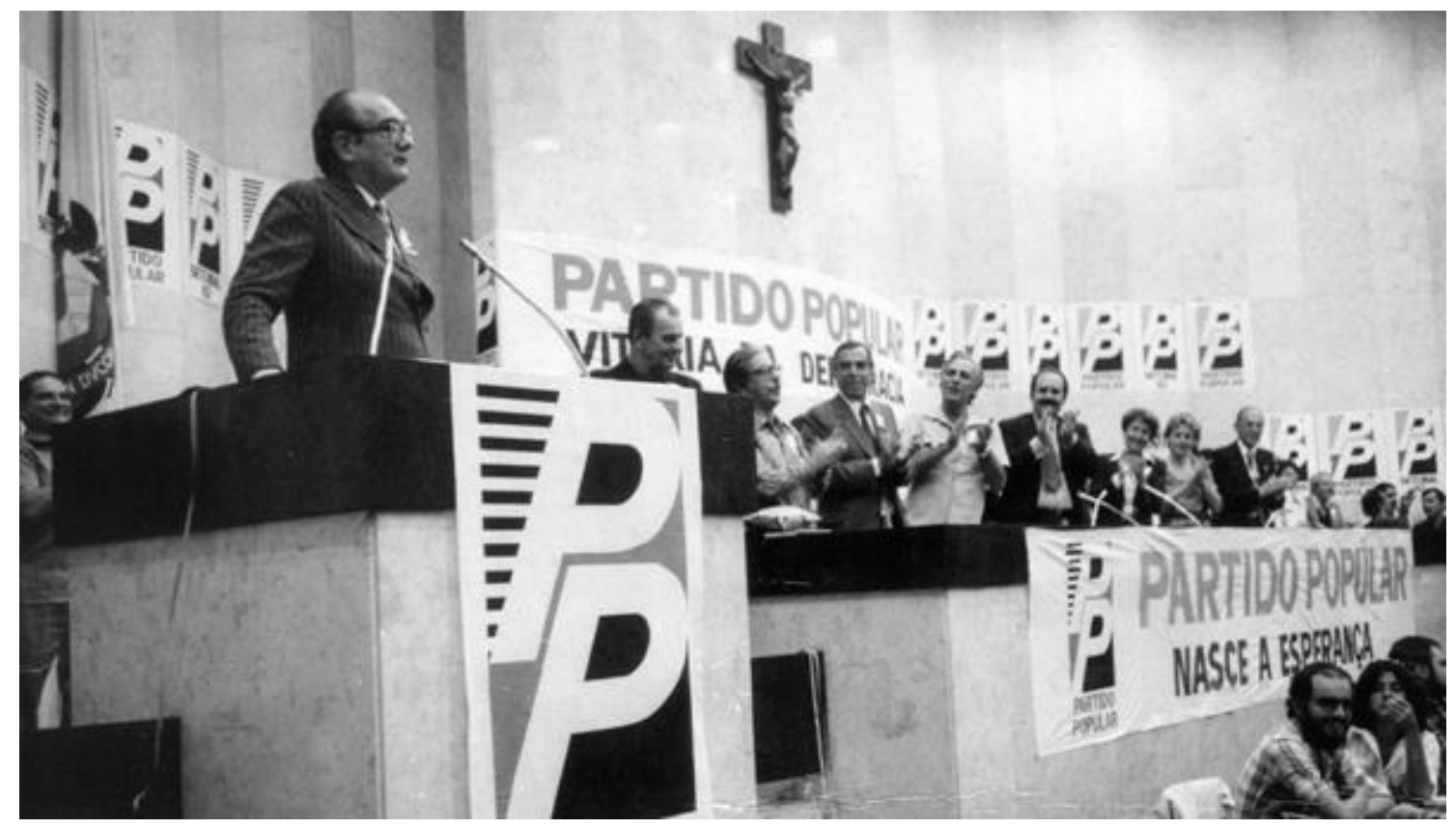

Olavo Setúbal discursa em Convenção do Partido Popular (acervo Olavo Setúbal - http://www.olavosetubal.org.br/ visitado em $3 / 03 / 2014)$ 


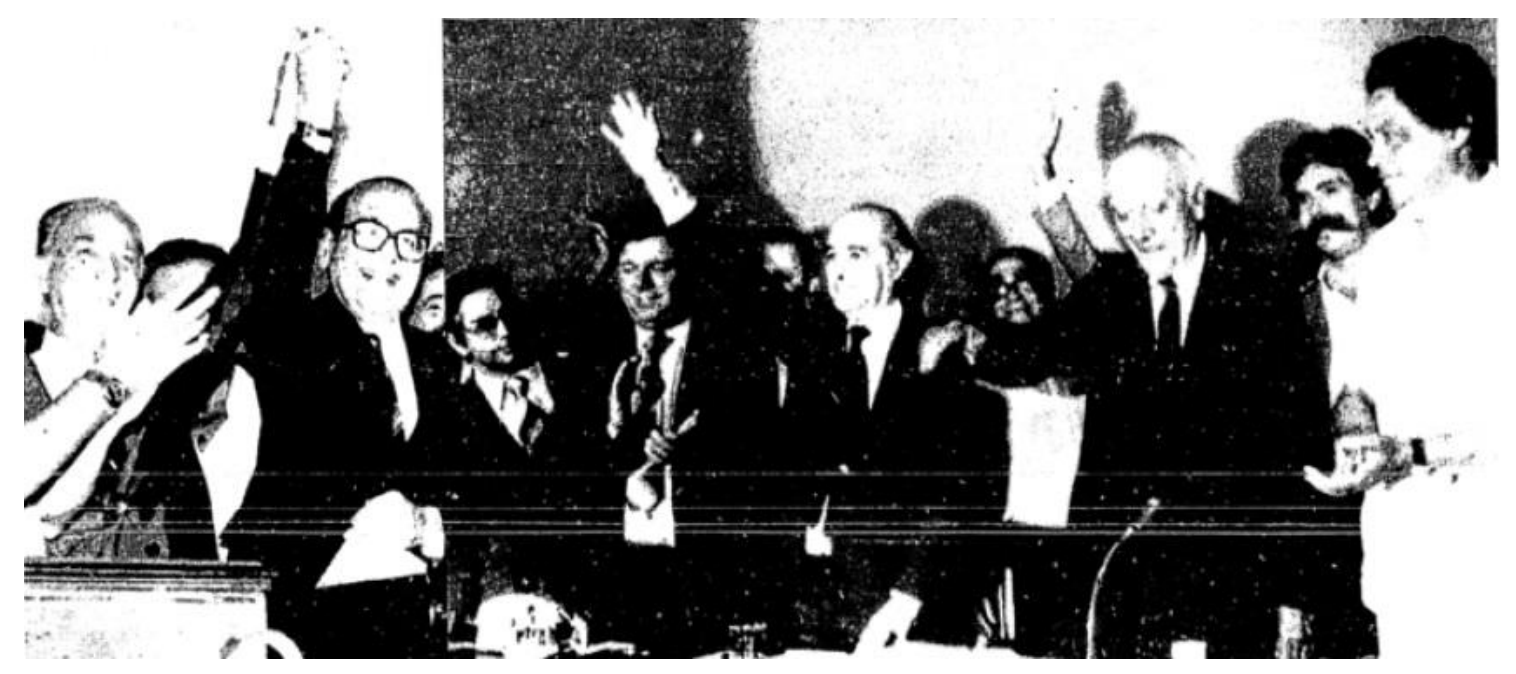

Convenção Nacional Conjunta que homologa a incorporação do PP ao PMDB. Folha de S. Paulo - 15/02/1982 p.1

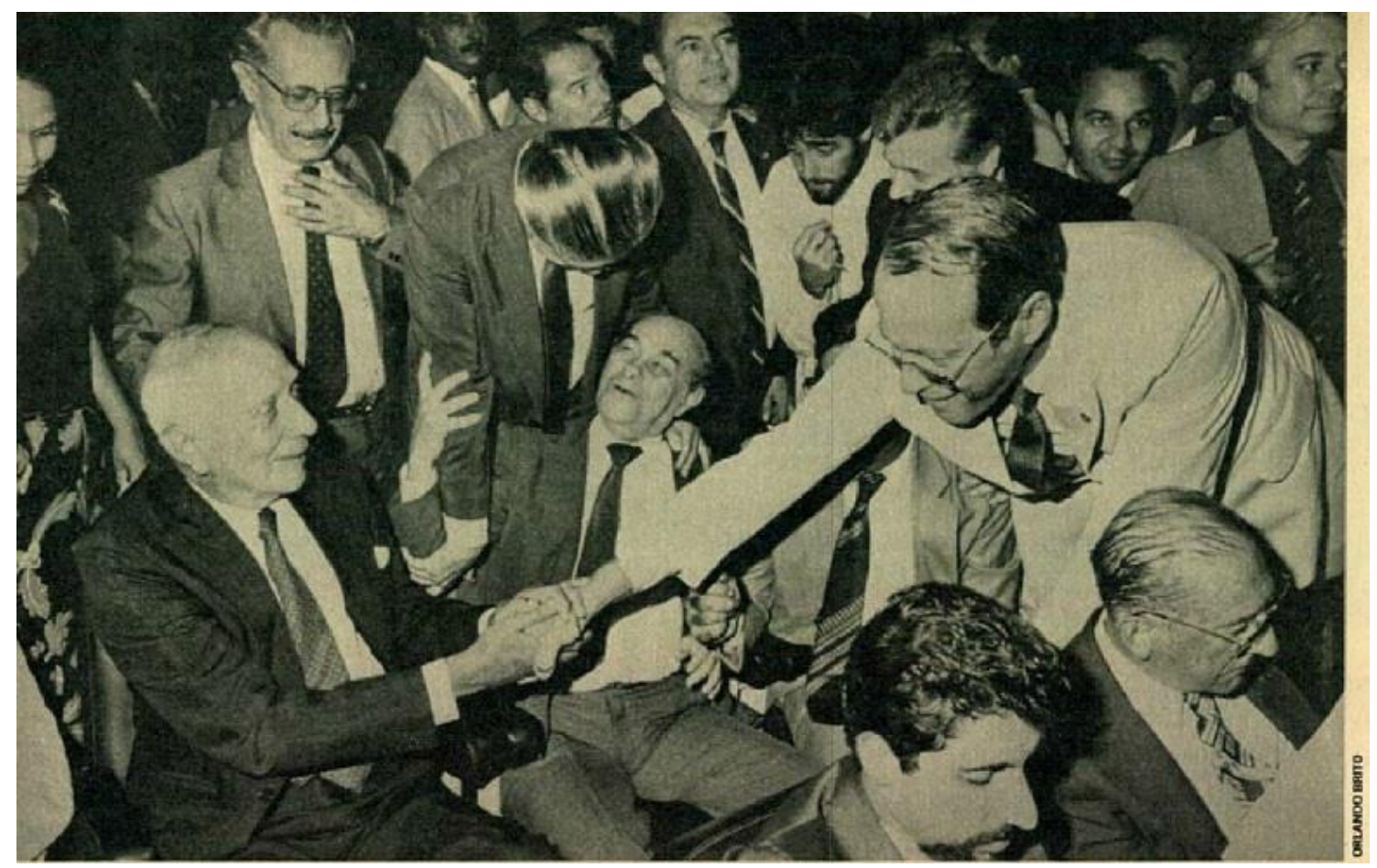

Ulysses Guimarães e Tancredo Neves recebem os cumprimentos ao ouvirem a decisão do TSE favorável à incorporação. Revista Veja $10 / 03 / 1982$, p. 24 


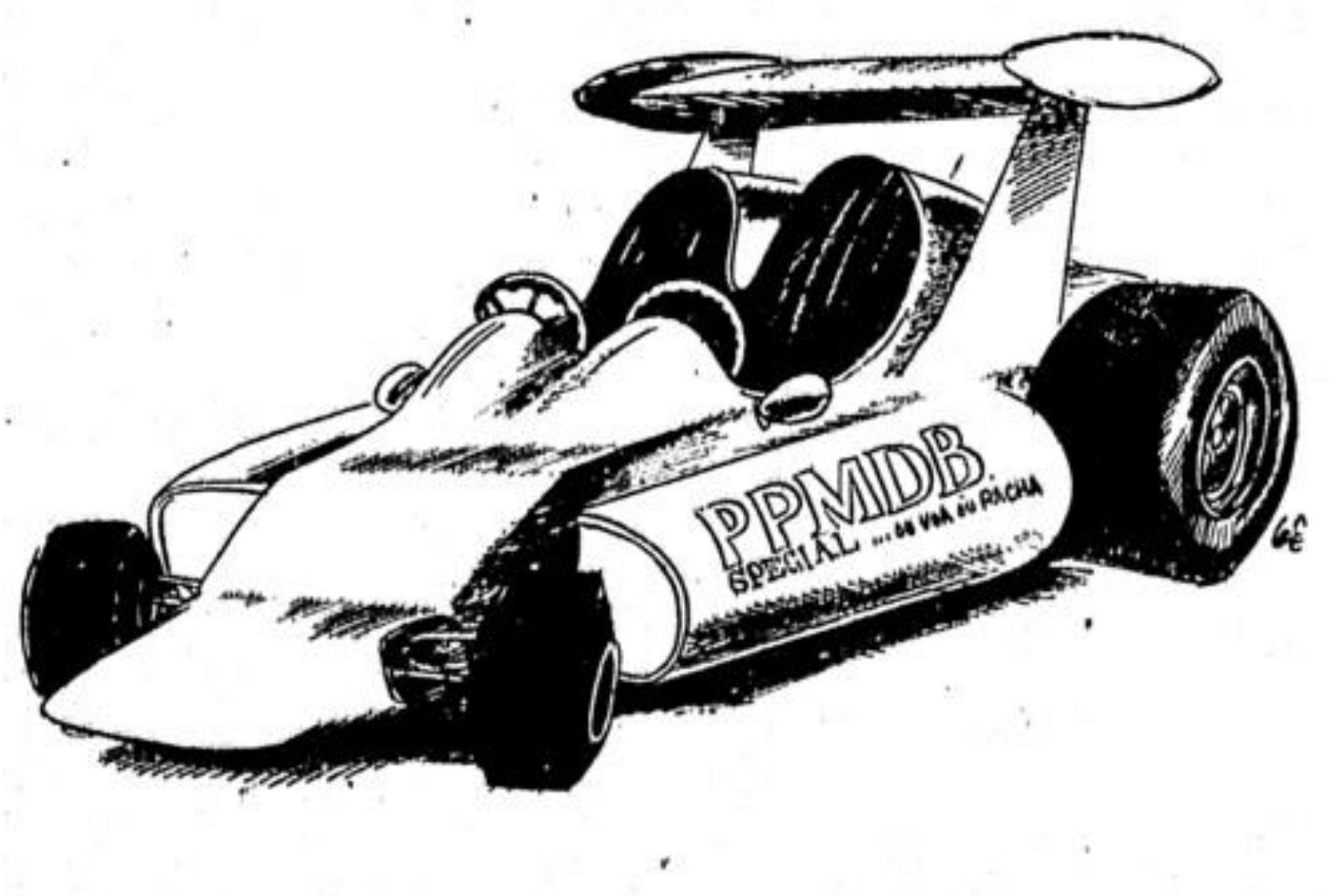

Charge publicada na Folha de S. Paulo - 7/01/1982, p. 2 


\section{Capítulo 4 \\ O PMDB e as eleições de 1982}

O objetivo deste último capítulo é apresentar outro indicador empírico que nos permite demonstrar o quanto a incorporação do PP contribuiu para o aumento da heterogeneidade interna do PMDB. Como vimos no Capítulo 2, o PMDB é um partido com fortes bases parlamentares desde sua gênese, mantendo essa característica em seu primeiro teste eleitoral. A eleição de 1982 lhe outorgou amplas bancadas tanto na Câmara dos Deputados quanto no Senado. Sabendo da força parlamentar apresentada pelo partido desde sua fundação, torna-se evidente que o Congresso Nacional é um importante locus para mensurar o quanto a incorporação do PP contribuiu para o aumento da heterogeneidade interna do PMDB.

Este capítulo se divide em três seções. Na primeira, apresentamos a conjuntura histórica das eleições de 1982 e os cargos que estiveram em disputa. Na segunda, será exposto um panorama geral do desempenho do partido naquelas eleições, com ênfase nos resultados do Congresso Nacional. Por fim, na última seção, fazemos uso de dados inéditos acerca da filiação partidária prévia dos candidatos eleitos pelo PMDB para o Congresso. Por meio desses dados, comprova-se o aumento de ex-arenistas no PMDB, egressos do PP, evidenciando a nova composição do partido dirigido por Ulysses Guimarães.

1. Conjuntura histórica das eleições de 1982

As eleições de 1982 foram a primeira disputa eleitoral desde que o pluripartidarismo havia sido restabelecido, em 1979, e consistiram no quarto de uma série de pleitos (ocorridos antes em 1974, 1976 e 1978) no contexto da “distensão lenta, gradual e segura" do Regime Militar. Segundo Fleischer (1988a, pp. 12-13), 
aquelas eleições foram "um divisor de águas mais ou menos no meio do caminho do processo de 'distensão-abertura'", que já durava 8 anos. Ainda segundo o autor, uma série de fatores contribuiu para o caráter daquela eleição: nela, a oposição pela primeira vez alcançou os governos estaduais de muitos Estados. Pela primeira vez também o partido de sustentação do Regime perdeu a maioria absoluta na Câmara, o que posteriormente propiciou suas primeiras derrotas em votações de decretos-lei desde 1964. Por fim, a nova composição do Congresso também teria importantes implicações na correlação de forças do Colégio Eleitoral de 1985, na convocação da Assembleia Nacional Constituinte e no restabelecimento das eleições para capitais de Estados e áreas de segurança nacional. Os três últimos aspectos excedem o recorte de tempo desta pesquisa e não serão analisados.

No pleito de 1982 cinco partidos apresentaram-se para o eleitorado: PDS, PMDB ("incorporado"), PDT, PTB e PT. No campo da oposição, a existência de mais de um partido - um contraste com a situação pré-1979 - implicava que cada um deles deveria desenvolver sua identidade própria perante o eleitorado (Keck, 1991, p.151).

Para o PMDB, as eleições de 1982 representavam a primeira chance real de o partido chegar ao cargo majoritário em alguns Estados. Para alcançar esse fim, o partido buscava se apresentar ao eleitorado como uma real alternativa de poder, sendo o herdeiro legítimo do antigo $\mathrm{MDB}$ e, por isso, o único partido viável de oposição (ibidem, p.146). Nesse sentido, a campanha do PMDB buscou atribuir um caráter plebiscitário e bipolarizado às eleições ${ }^{159}$. Seus dirigentes declaravam, visando canalizar os votos oposicionistas somente para si, que o voto no partido seria um "voto útil", que poderia levar pela primeira vez um partido de oposição a ter acesso às esferas de poder para fazer frente ao

\footnotetext{
${ }^{159}$ Uma visão até maniqueísta da política, como uma disputa entre o "bem" e o "mal", que preocupava setores do Regime Militar que acusam o PMDB de "revanchista".
} 
Regime. Ao observarmos os resultados das eleições, como faremos na próxima seção, nota-se que a estratégia obteve relativo sucesso. Apenas os Estados do Rio Grande do Sul e Rio de Janeiro constituem exceções, pois, naqueles estados, o PDT também se mostrava como um adversário forte (Estados estes onde o PDT conseguiu também "vestir a camisa da oposição viável” - idem) ${ }^{160}$.

Para as outras agremiações da oposição (no caso, o PT, o PTB e o PDT), aquele pleito representava uma disputa horizontal entre partidos, cujo objetivo era demarcar um território eleitoral próprio (Keck, 1991, p. 146) e também superar as barreiras percentuais estabelecidas pela nova legislação eleitoral para sua regulamentação (que só viriam a ser adiadas em uma data próxima ao pleito). Esses partidos tentavam se apresentar ao eleitorado como sendo também "viáveis" eleitoralmente, argumentando que tinham o direito de concorrer àquelas eleições. Ao mesmo tempo, acusavam o PMDB de ser um partido "eleitoreiro", uma verdadeira frente política, que reivindicava somente para si a condição de oposição ao regime.

As entrevistas concedidas por Ulysses Guimarães, então presidente nacional do PMDB, e Luís Inácio Lula da Silva, então presidente do PT, ao jornal Folha de S. Paulo expressam bem as visões de seus respectivos partidos sobre aquelas eleições e exemplificam o teor das opiniões dos partidos de oposição. Enquanto Ulysses declarava que "a comemoração do povo será no dia 15 de novembro, plebiscitando contra tudo que aí está", em menção da celebração do golpe de 1964 promovida pelo Regime ${ }^{161}$, Lula afirmava que "o adversário de seu partido nas urnas, naquela eleição, era o PMDB, apesar de o inimigo ser o PDS." 162

Antes de apresentar aqui os resultados das eleições de 1982, cabe destacar que o Regime fez uso de mais uma série de casuísmos

\footnotetext{
${ }^{160}$ Sobre a disputa entre PDT e PMDB no Rio Grande do Sul ver Trindade (2011).

${ }^{161}$ Folha de S. Paulo, 4/04/1982, p. 6 - "Para Ulysses, eleição será plebiscitária".

${ }^{162}$ Folha de S. Paulo, 16/05/1982, p.5 - "Nosso adversário é o PMDB, afirma Lula".
} 
antes do pleito, alterando aspectos então vigentes da legislação eleitoral. O governo temia que, caso se mantivesse a tendência de crescimento do desempenho eleitoral da oposição, sua sustentação majoritária no Congresso fosse prejudicada.

Então, por meio de duas medidas o Regime alterou a quantidade de cadeiras que estariam em disputa no Congresso Nacional: a elevação do Território de Rondônia à categoria de Estado e a adoção de um novo cálculo para a distribuição de cadeiras, de acordo com a população de cada estado, sobrerepresentando os Estados menos populosos, nos quais o Regime historicamente tinha um bom desempenho. Dessa forma, o número de cadeiras em disputa na Câmara subiu de 420 para 479 e a quantidade de vagas em disputa para o Senado foi aumentada em duas cadeiras.

O governo também adiou para as eleições de 1986 o prazo para o cumprimento das exigências percentuais eleitorais para a regulamentação dos partidos (vistas no Capítulo 2). Dessa forma, os pequenos partidos (PTB, PDT e PT) não perderiam as cadeiras que porventura ganhassem, fazendo com que a oposição continuasse dividida no âmbito legislativo.

Ademais, o Regime restabeleceu o quórum mínimo de $2 / 3$ para a aprovação de novas emendas constitucionais (para a qual a legislação anteriormente exigia apenas a maioria absoluta), dificultando mudanças constitucionais justamente em um momento no qual o PDS possuía uma bancada cada vez menos coesa e uma maioria cada vez mais exígua no Congresso. Por fim, abrandou as exigências para o lançamento de candidaturas a nível municipal, favorecendo os pequenos partidos e prejudicando o discurso de bipolarização das eleições que o PMDB procurava promover ${ }^{163}$.

\footnotetext{
${ }^{163}$ Houve ainda uma tentativa fracassada de implantação do voto de representação distrital misto, através da Emenda Constitucional n. 22, de 29 de junho de 1982, mas a Emenda nunca foi aplicada ao contexto político ficando apenas no texto jurídico, sendo revogada pela Emenda Constitucional n.25 em 1985. O regime também alterou a composição do futuro Colégio Eleitoral que elegeria o sucessor do Presidente
} 
Cabe lembrar que o "voto vinculado", medida estabelecida a partir do Pacote de Novembro, também vigoraria no pleito de 1982. Os eleitores seriam obrigados a votar apenas em candidatos de um mesmo partido para todos os cargos que estariam em disputa, a saber: vereadores, prefeitos, deputados estaduais, deputados federais, senadores, e governadores de estado.

2. O desempenho do PMDB em seu primeiro teste eleitoral

Tendo em mente que o PMDB contava com uma forte base parlamentar desde sua fundação (como demonstramos ao longo do Capítulo 2) e também com uma ampla rede organizativa (em parte herdada do Partido Popular, como demonstramos no Capítulo 3), cabe-nos agora analisar como o partido fez uso dessa sua estrutura organizativa em prol de um bom desempenho em seu primeiro teste eleitoral. A análise dos resultados das eleições para o Congresso Nacional, apresentados no final desta seção, será essencial para evidenciar, na última seção deste capítulo, o quanto o PMDB havia se transformado após apenas dois anos de funcionamento.

Como dito anteriormente, diferentemente dos partidos menores (com exceção dos candidatos do PDT no Rio de Janeiro e Rio Grande do Sul), o PMDB se apresentava àquele pleito como uma real alternativa de poder perante o eleitorado, efetivamente disputando com os candidatos do Regime a possibilidade de alcançar o Poder Executivo em muitos Estados. Por fazer uso de uma enorme rede organizativa, herdada ao tornar-se o que chamamos no capítulo anterior de "PPMDB", o partido pôde apresentar candidaturas para todos os principais cargos em disputa em todos os Estados da federação (governador, senador, deputado federal e deputado estadual). Reforçado pela incorporação do PP, o partido é aquele que, entre os partidos de oposição, apresentou o maior número de candidatos aos principais cargos em disputa.

Figueiredo com o intuito de manter o controle do seu processo sucessório, mas as consequências da medida excedem o recorte de tempo aqui estudado. 
Tabela 10. Quantidade de candidatos por partido em 1982

\begin{tabular}{l|c|c|c|c}
\hline \hline Partido & Governador & Senador & $\begin{array}{c}\text { Deputado } \\
\text { Federal }\end{array}$ & $\begin{array}{c}\text { Deputado } \\
\text { Estadual }\end{array}$ \\
\hline \hline PDS & 22 & 45 & 538 & 1335 \\
\hline PMDB & 22 & 45 & 523 & 1242 \\
\hline PT & 21 & 25 & 185 & 393 \\
\hline PDT & 12 & 12 & 147 & 308 \\
\hline PTB & 10 & 12 & 186 & 327 \\
\hline \hline
\end{tabular}

Fontes: Folha de S. Paulo - 14/11/1982 e elaboração própria a partir de dados disponíveis no Repositório de Dados Eleitorais do TSE

O desempenho geral do PMDB no pleito de 1982 foi bastante positivo.

Nas eleições municipais, realizadas por conta do adiamento das eleições de 1980, o partido mostrou a força de sua rede organizacional. Contando com uma rede de mais de 3.200 diretórios no momento das eleições ${ }^{164}$, o partido obteve um desempenho bastante expressivo, ainda mais se comparado ao dos outros partidos oposicionistas. Das 3.941 cidades que tiveram eleições para prefeito (todas em turno único, em acordo com a legislação do período), 1.377 tiveram prefeitos eleitos pertencentes à legenda, um percentual de $34,9 \%$ do total. O PMDB ficou até mesmo à frente do partido governista em alguns Estados importantes, sobretudo nos mais urbanizados (por exemplo, em São Paulo, onde o PMDB elegeu 308 prefeitos, e o PDS, 249) ${ }^{165}$. Os resultados deixaram claro que, no plano municipal, PDS e PMDB foram os partidos que mais puderam se beneficiar da estrutura organizativa que montaram e que herdaram de seus antecessores

\footnotetext{
${ }^{164}$ Folha de S. Paulo-02/05/1982, p.4

165 Analisando as eleições de 1986, Sadek (1989) nota a mudança das bases eleitorais do PMDB em relação ao desempenho do antigo MDB, evidenciando uma possível "interiorização" do partido. A vitória do PMDB em um grande número de cidades de São Paulo e Minas Gerais (incluído cidades pequenas) sugere que as bases eleitorais do partido poderiam estar se transformando desde 1982, em parte beneficiadas pela incorporação da rede organizacional do PP, mas esta é uma hipótese que necessita de comprovação futura.
} 
(respectivamente, Arena e MDB), cabendo aos outros partidos apenas $1 \%$ de todas as prefeituras do país ${ }^{166}$.

Tabela 11. Número de prefeitos eleitos por partido em $1982 * 167$

\begin{tabular}{lcc}
\hline \hline Partido & $\mathbf{N}$ & $\mathbf{\%}$ \\
\hline \hline PDS & 2533 & 64,3 \\
\hline PMDB & 1377 & 34,9 \\
\hline PDT & 22 & 0,6 \\
\hline PTB & 7 & 0,2 \\
\hline PT & 2 & 0,1 \\
\hline Total & $\mathbf{3 9 4 1}$ & $\mathbf{1 0 0}$ \\
\hline \hline
\end{tabular}

Fontes: Fleischer (2002), Nicolau (1998)

* Apenas as capitais de Estados e aqueles municípios que eram designados como "áreas de segurança nacional" e estâncias hidrominerais não puderam eleger seus prefeitos em 1982, algo em torno de 130 cidades.

Tabela 12. Porcentagem de vereadores eleitos por partido em 1982

\begin{tabular}{lc}
\hline \hline Partido & \% \\
\hline \hline PDS & 61,6 \\
\hline PMDB & 36,2 \\
\hline PDT & 1,4 \\
\hline PTB & 0,5 \\
\hline PT & 0,3 \\
\hline Total & $\mathbf{1 0 0}$ \\
\hline \hline
\end{tabular}

Fontes: Soares (1984)

As eleições para governador de Estado, por sua vez, representaram o grande cargo em disputa nas eleições de 1982, cargo para o qual não eram realizadas eleições diretas desde 1965. Como visto na Tabela 10, o PMDB foi um dos dois únicos partidos a apresentar candidatos em todos os vinte e dois Estados da União que tiveram eleições naquele ano, igualando-se neste quesito

\footnotetext{
${ }^{166}$ De acordo com Fleischer (1988a, p. 80) em alguns Estados o PMDB pulverizou o PDS a nível municipal por causa do efeito coattails "de cima para baixo", que fez com que os eleitores orientassem o seu voto primeiramente pelo candidato a governador do Estado, o resultado inverso do esperado pelos estrategistas políticos do Regime.

${ }^{167}$ Infelizmente, após consulta ao TSE, foi verificada pouca disponibilidade de dados a respeito das eleições municipais de 1982, o que nos impediu de realizar uma análise da distribuição geográfica das prefeituras conquistadas pelo partido. Felizmente, este fato não interfere nas conclusões desta pesquisa, mas torcemos para que no futuro novos dados venham à tona e permitam aos pesquisadores realizar essa análise com relação à primeira eleição do PMDB.
} 
apenas ao partido governista ${ }^{168}$. A amplitude de suas candidaturas é mais uma evidência da solidez de sua rede organizacional e de sua penetração territorial, em parte herdada do PP, como fica claro ao analisarmos os governadores eleitos pelo partido.

O PMDB conquistou o Poder Executivo em nove Estados da Federação: Acre, Amazonas, Pará, Goiás, Mato Grosso do Sul, Minas Gerais, Espírito Santo, São Paulo ${ }^{169}$ e Paraná. Em dois desses Estados, os seus governadores eleitos haviam sido filiados ao PP antes da incorporação: Tancredo Neves, em Minas Gerais, e Gilberto Mestrinho, no Amazonas. O único governador eleito pela oposição que não era filiado ao PMDB foi Leonel Brizola, no Rio de Janeiro, eleito pelo PDT $^{170}$. Por sua vez, o PDS, partido governista, elegeu os outros doze governadores naquela data ${ }^{171}$.

A disparidade entre o número de eleitos da oposição e do governo, e entre o PMDB e os demais partidos de oposição, comprova a penetração que esse partido detinha já em seu primeiro teste eleitoral.

Tabela 13. Governadores eleitos em 1982

\begin{tabular}{l|c|c}
\hline \hline Região/Estado & Eleito & Partido \\
\hline \hline Norte & Nabor Teles & PMDB \\
\hline Acre & $\begin{array}{c}\text { Gilberto } \\
\text { Mestrinho* }\end{array}$ & PMDB \\
\hline Amazonas & Jáder Barbalho & PMDB \\
\hline Pará & \multicolumn{2}{|c}{ Pivaldo Suruagy } \\
\hline Nordeste & João Durval & PDS \\
\hline Bahia & Luís Gonzaga & PDS \\
\hline Ceará & Mota & PDS \\
\hline Maranhão & Luis Alves Coelho &
\end{tabular}

\footnotetext{
${ }^{168}$ Amapá e Roraima, por serem considerados Territórios, e Rondônia, por mais um casuísmo do Regime, não tiveram eleições para este cargo naquele ano. O Estado de Rondônia teve o seu primeiro governador nomeado de maneira indireta pelo Presidente da República, ao invés de realizar eleições como os outros estados fizeram naquele ano.

${ }^{169}$ Sobre a campanha do PMDB para as eleições para Governador em São Paulo, ver Azevedo (1995).

${ }^{170}$ Como visto na Tabela 10, em muitos Estados o PDT e o PTB nem mesmo apresentaram candidaturas próprias.

${ }^{171}$ O PDS também era a sigla do governador nomeado para o recém criado Estado de Rondônia.
} 


\begin{tabular}{|c|c|c|}
\hline & Rocha & \\
\hline Paraíba & Wilson Braga & PDS \\
\hline Pernambuco & $\begin{array}{c}\text { Roberto } \\
\text { Magalhães }\end{array}$ & PDS \\
\hline Piauí & Hugo Napoleão & PDS \\
\hline $\begin{array}{l}\text { Rio Grande do } \\
\text { Norte }\end{array}$ & $\begin{array}{c}\text { José Agripino } \\
\text { Maia }\end{array}$ & PDS \\
\hline Sergipe & João Alves Filho & PDS \\
\hline \multicolumn{3}{|l|}{ Centro-Oeste } \\
\hline Goiás & Íris Rezende & PMDB \\
\hline Mato Grosso & Júlio Campos & PDS \\
\hline $\begin{array}{l}\text { Mato Grosso do } \\
\text { Sul }\end{array}$ & $\begin{array}{c}\text { Wilson Barbosa } \\
\text { Martins }\end{array}$ & PMDB \\
\hline \multicolumn{3}{|l|}{ Sudeste } \\
\hline Minas Gerais & Tancredo Neves* & PMDB \\
\hline Espírito Santo & Gerson Camata** & PMDB \\
\hline Rio de Janeiro & Leonel Brizola & PDT \\
\hline São Paulo & Franco Montoro & PMDB \\
\hline \multicolumn{3}{|l|}{ Sul } \\
\hline Paraná & José Richa & PMDB \\
\hline Rio Grande do Sul & Jair Soares & PDS \\
\hline Santa Catarina & Espiridião Amin & PDS \\
\hline
\end{tabular}

Fontes: Nicolau (1998)

*Ex-pepistas

$* *$ Ex-arenista

Nas eleições para as Assembleias Legislativas (ALs) o desempenho geral do PMDB foi próximo ao desempenho do PDS no que concerne à porcentagem de votos obtidos, mas com relação às cadeiras conquistadas obteve 73 cadeiras a menos que o partido governista. Por sua vez, os resultados dos partidos menores evidenciaram o seu caráter regional, resultado direto da sua dificuldade em se estruturar nacionalmente ${ }^{172}$.

A diferença entre o total de votos do PDS e o do PMDB para as ALs foi de menos de 100 mil votos, mas, ao levarmos em conta os votos do PTB, do PDT e do PT, nota-se que as oposições tiveram juntas um desempenho melhor do que o partido do governo.

\footnotetext{
${ }^{172} \mathrm{O}$ desempenho nas eleições para as ALs teria extrema importância para a composição do Colégio Eleitoral que se reuniria em 1985 para eleger o sucessor do então Presidente Figueiredo. Sua composição havia sido alterada pelo Regime em mais um dos casuísmos pré-eleitorais para beneficiar o partido governista. Porém, como dito anteriormente, implicações de longo prazo das eleições de 1982 para a composição do Colégio eleitoral estão aquém dos objetivos desta pesquisa. Sobre a composição do Colégio Eleitoral de 1985, ver Fleischer (1988b).
} 
Enquanto o PDS elegeu 477 deputados estaduais (em sua maioria concentrados na região Nordeste), o PMDB elegeu outros 404, e os outros partidos de oposição dividiram entre si os outros 66 deputados (em sua quase totalidade concentrados nos Estados do Sudeste).

Tabela 14. Cadeiras obtidas, percentual de votos e votação total por partido nas eleições para as Assembleias Legislativas em 1982

\begin{tabular}{lccc}
\hline \hline Partido & Cadeiras obtidas & $\%$ & Total de votos \\
\hline \hline PDS & 477 & 50,3 & 17.406 .058 \\
\hline PMDB & 404 & 42,7 & 17.313 .056 \\
\hline PDT & 35 & 3,8 & 2.320 .777 \\
\hline PTB & 18 & 1,9 & 1.787 .072 \\
\hline PT & 13 & 1,4 & 1.429 .363 \\
\hline Total & 947 & & 40.256 .326 \\
\hline \hline
\end{tabular}

Fontes: Nicolau (1998)

Tabela 15. Cadeiras e percentual de votos obtidos por partido e por Estado nas eleições para as Assembleias Legislativas em 1982

\begin{tabular}{|c|c|c|c|c|c|c|c|c|c|c|c|}
\hline & \multicolumn{2}{|c|}{ PDS } & \multicolumn{2}{|c|}{ PMDB } & \multicolumn{2}{|c|}{ PDT } & \multicolumn{2}{|c|}{ РTB } & \multicolumn{2}{|c|}{ PT } & \multirow[b]{2}{*}{ Total } \\
\hline Região/Estado & $\mathrm{N}$ & $\%$ & $\mathrm{~N}$ & $\%$ & $\mathrm{~N}$ & $\%$ & $\mathrm{~N}$ & $\%$ & $\mathrm{~N}$ & $\%$ & \\
\hline Norte & 56 & 47,7 & 54 & 49,5 & & & & 0,9 & 1 & 1,9 & \\
\hline Rondônia & 15 & 58,4 & 9 & 38,1 & & & & & & 3,5 & 24 \\
\hline Acre & 11 & 45,1 & 12 & 45,6 & & & & 3,5 & 1 & 5,9 & 24 \\
\hline Amazonas & 11 & 44,6 & 13 & 52,8 & & & & 1,1 & & 1,4 & 24 \\
\hline Pará & 19 & 47,2 & 20 & 50,5 & & & & 0,8 & & 1,4 & 39 \\
\hline Nordeste & 223 & 65,1 & 112 & 34,1 & & 0,1 & & 0,1 & & 0,6 & \\
\hline Maranhão & 33 & 78,8 & 8 & 18,8 & & 1,4 & & 0,1 & & 1,0 & 41 \\
\hline Piauí & 17 & 62,1 & 10 & 37,1 & & & & & & 0,8 & 27 \\
\hline Ceará & 34 & 73,8 & 12 & 25,7 & & & & & & 0,5 & 46 \\
\hline $\begin{array}{l}\text { Rio Grande do } \\
\text { Norte }\end{array}$ & 15 & 60,4 & 9 & 39,1 & & & & 0,1 & & 0,4 & 24 \\
\hline Paraíba & 22 & 60,1 & 14 & 39,5 & & & & & & 0,4 & 36 \\
\hline Pernambuco & 28 & 55,9 & 22 & 43,4 & & & & 0,4 & & 0,2 & 50 \\
\hline Alagoas & 15 & 60,5 & 9 & 39,5 & & & & & & & 24 \\
\hline Sergipe & 19 & 77,4 & 5 & 21,8 & & 0,4 & & & & 0,4 & 24 \\
\hline Bahia & 40 & 63,5 & 23 & 35,6 & & & & & & 0,9 & 63 \\
\hline Sudeste & 91 & 32,8 & 114 & 43,7 & 24 & 8,2 & 18 & 8,9 & 12 & 6,5 & \\
\hline Minas Gerais & 37 & 47,3 & 40 & 50,4 & & 0,2 & & & 1 & 2,1 & 78 \\
\hline Espírito Santo & 11 & 40,9 & 16 & 57,5 & & 0,2 & & & & 1,4 & 27 \\
\hline Rio de Janeiro & 21 & 29,9 & 16 & 23,1 & 24 & 33,2 & 7 & 10,8 & 2 & 3,1 & 60 \\
\hline São Paulo & 22 & 26,4 & 42 & 49,1 & & 0,8 & 11 & 13,0 & 9 & 10,7 & 84 \\
\hline Sul & 69 & 42,6 & 74 & 46,9 & 11 & 9,4 & & 0,4 & & 0,8 & \\
\hline Paraná & 24 & 40,5 & 34 & 57,9 & & 0,2 & & 1,0 & & 0,4 & 58 \\
\hline
\end{tabular}




\begin{tabular}{l|l|l|l|l|l|l|l|l|l|l|l}
\hline $\begin{array}{l}\text { Santa } \\
\text { Catarina }\end{array}$ & 21 & 51,2 & 19 & 48,0 & & 0,3 & & 0,1 & & 0,4 & 40 \\
\hline $\begin{array}{l}\text { Rio Grande do } \\
\text { Sul }\end{array}$ & 24 & 40,0 & 21 & 36,8 & 11 & 21,9 & & & & 1,3 & 56 \\
\hline \hline Centro-Oeste & 38 & 40,1 & 50 & 59,0 & & 0,3 & & & & 0,6 & \\
\hline $\begin{array}{l}\text { Mato Grosso } \\
\text { do Sul }\end{array}$ & 12 & 47,6 & 12 & 50,4 & & 1,0 & & & & 0,9 & 24 \\
\hline Mato Grosso & 13 & 53,4 & 11 & 46,1 & & 0,3 & & & & 0,2 & \\
\hline Goiás & 13 & 33,9 & 27 & 65,4 & & 0,1 & & & & 0,7 & \\
\hline \hline Brasil & & 43,2 & & 43,0 & & 5,8 & & 4,4 & & 3,6 & \\
\hline $\begin{array}{l}\text { Total de } \\
\text { cadeiras }\end{array}$ & 477 & & 404 & & 35 & & 18 & & 13 & & 947 \\
\hline \hline
\end{tabular}

Fontes: Nicolau (1998, para as porcentagens), e elaboração própria a partir de dados coletados no Repositório de Dados Eleitorais do TSE para a quantidade de cadeiras eleitas por cada partido.

\section{Tabela 16. Distribuição regional dos Deputados Estaduais eleitos pelos partidos em 1982}

\begin{tabular}{l|c|c|c|c|c}
\hline \hline & PDS & PMDB & PDT & PTB & PT \\
\hline \hline Norte & $11,7 \%$ & $13,3 \%$ & $0 \%$ & $0 \%$ & $7,7 \%$ \\
\hline Nordeste & $46,7 \%$ & $27,7 \%$ & $0 \%$ & $0 \%$ & $0 \%$ \\
\hline $\begin{array}{l}\text { Centro- } \\
\text { Oeste }\end{array}$ & $7,9 \%$ & $12,3 \%$ & $0 \%$ & $0 \%$ & $0 \%$ \\
\hline Sudeste & $19 \%$ & $28,2 \%$ & $68,6 \%$ & $100 \%$ & $92,3 \%$ \\
\hline Sul & $14,4 \%$ & $18,3 \%$ & $31,4 \%$ & $0 \%$ & $0 \%$ \\
\hline Total & $100 \%$ & $100 \%$ & $100 \%$ & $100 \%$ & $100 \%$ \\
\hline
\end{tabular}

Fontes: elaboração própria a partir dos dados da tabela anterior

Por fim, o resultado das eleições para o Congresso Nacional, que servirá como base para analisarmos o aumento da heterogeneidade interna do PMDB na última seção deste capítulo.

Com relação ao Senado Federal, haviam 25 cadeiras em disputa nas eleições de 1982, sendo que o Estado de Rondônia elegeria três representantes (um senador com mandato de 8 anos e outros dois senadores com mandatos de 4 anos). No momento das eleições, a bancada do governo era composta por 36 senadores, frente aos 31 senadores da oposição (dos quais 29 pertenciam ao PMDB). Das cadeiras que competiam à oposição, 18 teriam que ser renovadas 
em 1982, pois tratavam-se de senadores em final de mandato (eleitos em 1974) ${ }^{173}$.

Como resultado final, das 25 cadeiras em disputa, o PMDB elegeu nove senadores, apresentando um resultado menor do que o do PDS, que elegeu 15, mas à frente do PDT que elegeu apenas um único senador. Os três senadores eleitos pelo recém-criado Estado de Rondônia pertenciam ao partido do governo. As novas bancadas dos partidos no Senado Federal mostravam que o governo havia conseguido manter sua maioria naquela casa, contando a partir de então com 46 senadores $(66,7 \%)$, frente aos 23 oposicionistas (21 do PMDB, 1 do PDT e 1 do PT).

Tabela 17. Senadores eleitos em 1982

\begin{tabular}{|c|c|c|}
\hline & Eleito & Partido \\
\hline \multicolumn{3}{|l|}{ Norte } \\
\hline Acre & Mário Maia & PMDB \\
\hline Amazonas & Fábio Lucena & PMDB \\
\hline Pará & Hélio Gueiros & PMDB \\
\hline Rondônia & $\begin{array}{c}\text { Odacir Soares } \\
\text { Reinaldo Galvão } \\
\text { Modesto } \\
\text { Claudionor Couto } \\
\text { Roriz }\end{array}$ & $\begin{array}{l}\text { PDS } \\
\text { PDS } \\
\text { PDS }\end{array}$ \\
\hline \multicolumn{3}{|l|}{ Nordeste } \\
\hline Alagoas & $\begin{array}{l}\text { Guilherme } \\
\text { Palmeira }\end{array}$ & PDS \\
\hline Bahia & Luiz Viana Filho & PDS \\
\hline Ceará & Virgílio Távora & PDS \\
\hline Maranhão & João Castelo & PDS \\
\hline Paraíba & $\begin{array}{c}\text { Marcondes } \\
\text { Gadelha }\end{array}$ & PDS \\
\hline Pernambuco & Marco Maciel & PDS \\
\hline Piauí & João Lobo & PDS \\
\hline $\begin{array}{l}\text { Rio Grande do } \\
\text { Norte }\end{array}$ & $\begin{array}{c}\text { Carlos Alberto } \\
\text { Souza }\end{array}$ & PDS \\
\hline Sergipe & Albano Franco & PDS \\
\hline \multicolumn{3}{|l|}{ Centro-Oeste } \\
\hline Goiás & $\begin{array}{c}\text { Mauro Borges } \\
\text { Teixeira }\end{array}$ & PMDB \\
\hline
\end{tabular}

173 Cabe destacar que alguns senadores da oposição que ainda teriam mais quatro anos de mandato decidiram disputar eleições para outros cargos eletivos, abrindo caminho para seus suplentes assumirem (como seria o caso de Franco Montoro, em São Paulo). 


\begin{tabular}{|c|c|c|}
\hline Mato Grosso & Roberto Campos & PDS \\
\hline $\begin{array}{l}\text { Mato Grosso do } \\
\text { Sul }\end{array}$ & Marcelo Miranda & PMDB \\
\hline \multicolumn{3}{|l|}{ Sudeste } \\
\hline Minas Gerais & Itamar Franco & PMDB \\
\hline Espírito Santo & $\begin{array}{c}\text { José Inácio } \\
\text { Ferreira }\end{array}$ & PMDB \\
\hline Rio de Janeiro & Saturnino Braga & PDT \\
\hline São Paulo & Severo Gomes & PMDB \\
\hline \multicolumn{3}{|l|}{ Sul } \\
\hline Paraná & Álvaro Dias & PMDB \\
\hline Rio Grande do Sul & Carlos Chiarelli & PDS \\
\hline Santa Catarina & Jorge Bornhausen & PDS \\
\hline
\end{tabular}

Fonte: Nicolau (1998)

Tabela 18. Tamanho das bancadas no Senado Federal após as eleições de 1982

\begin{tabular}{lcc}
\hline \hline Partido & $\mathbf{N}$ & $\mathbf{\%}$ \\
\hline \hline PDS & 46 & $66,7 \%$ \\
\hline PMDB & 21 & $30,4 \%$ \\
\hline PDT & 1 & $1,4 \%$ \\
\hline PTB & 0 & $0 \%$ \\
\hline PT & 1 & $1,4 \%$ \\
\hline Total & 69 & 100 \\
\hline \hline
\end{tabular}

Fonte: Britto (1) $\overline{\overline{988, \text { p. 245) e Folha de S. Paulo-01/ }}} 02 / 1983$, p. 4

Com relação à Câmara dos Deputados, no momento posterior à incorporação do PP e prévio às eleições de 1982, o PMDB contava com uma bancada de 180 deputados federais (ver Tabela 9 do Capítulo 3). Após as eleições, o partido passou a ter uma bancada composta por duzentos deputados federais, apresentando um desempenho menor que o do PDS (que elege 235), mas à frente dos outros partidos de oposição (que elegem os outros 44 deputados) ${ }^{174}$.

Nas regiões Norte, Nordeste e Centro-Oeste, todas as cadeiras em disputa para a Câmara foram divididas entre candidatos do PDS e do PMDB, enquanto que os "pequenos partidos" elegeram representantes apenas nos Estados das regiões Sul e Sudeste. Na região Norte, apesar de ter apresentado um percentual de votos

\footnotetext{
${ }^{174}$ Pela primeira vez, a soma de todos os deputados eleitos pela oposição superava o tamanho da bancada do partido governista.
} 
similar ao partido governista, o PMDB elegeu 19 deputados federais, enquanto o PDS elegeu $28^{175}$. Na região Nordeste, o PMDB elegeu apenas a metade da quantidade de eleitos pelo PDS: foram 50 eleitos pelo partido frente aos 99 eleitos pelo governo.

Na região Sudeste, os resultados das oposições foram os mais pulverizados, já que foi a única região na qual todos os partidos elegeram representantes. Em todos os seus Estados as oposições elegeram mais deputados que o governo, sendo que o PMDB o superava em Minas, Espírito Santo e São Paulo. Apenas no Rio de Janeiro, impulsionado pela candidatura vencedora de Leonel Brizola ao governo do Estado, o PDT elegeu mais deputados que qualquer outro partido.

Na região Sul, o PMDB elegeu mais deputados que o PDS em dois Estados, ficando atrás apenas no estado do Rio Grande do Sul, onde o desempenho do PDT logrou dividir os deputados eleitos pela oposição.

$\mathrm{Na}$ região Centro-Oeste, o PMDB elegeu mais representantes que o PDS, com destaque para os onze eleitos em Goiás frente aos cinco eleitos pelo partido governista.

Tabela 19. Cadeiras obtidas e percentual de votos total por partido e por Estado nas eleições para a Câmara dos Deputados em 1982

\begin{tabular}{l|c|c|c|c|c|c|c|c|c|c|c}
\hline \hline & \multicolumn{2}{|c|}{ PDS } & \multicolumn{2}{c|}{ PMDB } & \multicolumn{2}{c|}{ PDT } & \multicolumn{2}{|c|}{ PTB } & \multicolumn{2}{|c|}{ PT } & Total \\
\hline \hline Região/Estado & $\mathrm{N}$ & $\%$ & $\mathrm{~N}$ & $\%$ & $\mathrm{~N}$ & $\%$ & $\mathrm{~N}$ & $\%$ & $\mathrm{~N}$ & $\%$ & \\
\hline Norte & $\mathbf{2 8}$ & $\mathbf{4 9 , 2}$ & $\mathbf{1 9}$ & $\mathbf{4 8 , 1}$ & & $\mathbf{0}$ & & $\mathbf{0 , 9}$ & & $\mathbf{1 , 9}$ & $\mathbf{4 7}$ \\
\hline Rondônia & 5 & 57,8 & 3 & 38,7 & & & & & & 3,5 & 8 \\
\hline Acre & 4 & 44,4 & 4 & 46 & & & & 3,5 & & 6,1 & 8 \\
\hline Amazonas & 4 & 44 & 4 & 53,4 & & & & 1,1 & & 1,4 & 8 \\
\hline Roraima & 4 & 74,3 & & 24,4 & & 1,3 & & 0 & & & 4 \\
\hline Pará & 7 & 47,6 & 8 & 50,2 & & & & 0,8 & & 1,4 & 15 \\
\hline Amapá & 4 & 79,3 & & 17,3 & & & & & & 3,4 & 4 \\
\hline \hline Nordeste & $\mathbf{9 9}$ & $\mathbf{6 4 , 7}$ & $\mathbf{5 0}$ & $\mathbf{3 4 , 5}$ & & $\mathbf{0 , 1}$ & & $\mathbf{0 , 1}$ & & $\mathbf{0 , 6}$ & $\mathbf{1 4 9}$ \\
\hline Maranhão & 14 & 78,5 & 3 & 19,2 & & 1,4 & & & & 1 & 17 \\
\hline Piauí & 6 & 61,6 & 3 & 37,6 & & & & & & 0,8 & 9 \\
\hline Ceará & 17 & 73,9 & 5 & 25,6 & & & & & & 0,5 & $\mathbf{2 2}$ \\
\hline
\end{tabular}

${ }^{175}$ Cabe apontar que em Roraima todos os quatro deputados eleitos eram do PDS. 


\begin{tabular}{|c|c|c|c|c|c|c|c|c|c|c|c|}
\hline $\begin{array}{l}\text { Rio Grande do } \\
\text { Norte }\end{array}$ & 5 & 59,7 & 3 & 39,8 & & & & 0,1 & & 0,4 & 8 \\
\hline Paraíba & 7 & 60 & 5 & 39,6 & & & & & & 0,4 & 12 \\
\hline Pernambuco & 14 & 54,8 & 12 & 44,5 & & & & 0,4 & & 0,2 & 26 \\
\hline Alagoas & 5 & 60,1 & 3 & 39,9 & & & & & & & 8 \\
\hline Sergipe & 6 & 76,7 & 2 & 22,6 & & 0,3 & & & & 0,4 & 8 \\
\hline Bahia & 25 & 63,3 & 14 & 35,8 & & & & & & 0,9 & 39 \\
\hline Sudeste & 60 & 36,5 & 72 & 43,4 & 16 & 8,3 & 13 & 8,9 & 8 & 6,5 & 169 \\
\hline Minas Gerais & 26 & 47,3 & 27 & 50,3 & & 0,2 & & & 1 & 2,1 & 54 \\
\hline Espírito Santo & 4 & 40,4 & 5 & 58,1 & & 0,2 & & & & 1,4 & 9 \\
\hline Rio de Janeiro & 14 & 29,9 & 10 & 22,6 & 16 & 33,8 & 5 & 10,7 & 1 & 3 & 46 \\
\hline São Paulo & 16 & 36,5 & 30 & 66,6 & & 1,1 & 8 & 17,8 & 6 & 14,5 & 60 \\
\hline Sul & 35 & 42,4 & 40 & 47,1 & 7 & 9,3 & & 0,4 & & 0,8 & 32 \\
\hline Paraná & 14 & 40,1 & 20 & 58,2 & & 0,2 & & 1 & & 0,4 & 34 \\
\hline $\begin{array}{l}\text { Santa } \\
\text { Catarina }\end{array}$ & 8 & 50,7 & 8 & 48,5 & & 0,3 & & 0,1 & & 0,4 & 16 \\
\hline $\begin{array}{l}\text { Rio Grande do } \\
\text { Sul }\end{array}$ & 13 & 40,1 & 12 & 36,8 & 7 & 21,8 & & & & 1,4 & 32 \\
\hline Centro Oeste & 13 & 39,7 & 19 & 59,3 & & 0,3 & & & & 0,6 & 32 \\
\hline $\begin{array}{l}\text { Mato Grosso } \\
\text { do Sul }\end{array}$ & 4 & 47,1 & 4 & 51 & & 1 & & & & 0,9 & 8 \\
\hline Mato Grosso & 4 & 52,8 & 4 & 46,7 & & 0,2 & & & & 0,2 & 8 \\
\hline Goiás & 5 & 33,6 & 11 & 65,7 & & 0,1 & & & & 0,7 & 16 \\
\hline Brasil & & 43,2 & & 43 & & 5,8 & & 4,4 & & 3,5 & \\
\hline $\begin{array}{l}\text { Total de } \\
\text { cadeiras }\end{array}$ & \multicolumn{2}{|c|}{235} & \multicolumn{2}{|c|}{200} & \multicolumn{2}{|c|}{23} & \multicolumn{2}{|c|}{13} & \multicolumn{2}{|r|}{0} & 479 \\
\hline $\begin{array}{l}\text { Porcentagem } \\
\text { da Câmara }\end{array}$ & \multicolumn{2}{|c|}{49,1} & \multicolumn{2}{|c|}{41,8} & \multicolumn{2}{|c|}{4,8} & \multicolumn{2}{|c|}{2,7} & \multicolumn{2}{|c|}{1,7} & 100 \\
\hline
\end{tabular}

Fontes: Reproduzido de Nicolau (1998, ps. 52, 73,85)

Tabela 20. Distribuição regional dos deputados federais eleitos pelos partidos em 1982

\begin{tabular}{l|c|c|c|c|c}
\hline \hline & PDS & PMDB & PDT & PTB & PT \\
\hline \hline Norte & $11,9 \%$ & $9,5 \%$ & $0 \%$ & $0 \%$ & $0 \%$ \\
\hline Nordeste & $42,1 \%$ & $25 \%$ & $0 \%$ & $0 \%$ & $0 \%$ \\
\hline $\begin{array}{l}\text { Centro- } \\
\text { Oeste }\end{array}$ & $5,5 \%$ & $9,5 \%$ & $0 \%$ & $0 \%$ & $0 \%$ \\
\hline Sudeste & $25,5 \%$ & $36 \%$ & $69,5 \%$ & $100 \%$ & $100 \%$ \\
\hline Sul & $14,9 \%$ & $20 \%$ & $30,5 \%$ & $0 \%$ & $0 \%$ \\
\hline Total & $100 \%$ & $100 \%$ & $100 \%$ & $100 \%$ & $100 \%$ \\
\hline \hline
\end{tabular}

Fontes: elaboração própria a partir dos dados da tabela anterior

Os dados apresentados nesta seção comprovam a força parlamentar que o PMDB possuía no Congresso Nacional desde sua gênese, e também o quanto esse locus pode nos fornecer informações para mensurar as consequências do processo de incorporação do PP para o aumento 
da heterogeneidade interna do PMDB. Na Câmara dos Deputados, o partido possuía uma bancada de 115 deputados $(27,38 \%$ do total) no momento de sua fundação e, após o resultado das eleições de 1982, passaria a ter uma bancada composta por 200 deputados federais $(42,64 \%$ da representação naquela Casa). No Senado, por outro lado, o partido havia perdido uma cadeira em relação ao momento de sua fundação, passando de $22(32,83 \%)$ para 21 senadores $(30,43 \%)$, mas ainda assim manteve-se no posto de detentor da maior bancada dos partidos de oposição.

3. O resultado das eleições e o aumento da heterogeneidade interna do PMDB

A análise do desempenho do PMDB nas eleições para o Congresso Nacional, em 1982, fornece mais um indicador empírico por meio do qual é possível mensurar o quanto a composição interna do partido havia mudado desde sua fundação e evidenciando o quanto o aumento da sua heterogeneidade foi impulsionado pela incorporação do PP. Os dados acerca da filiação partidária pregressa dos eleitos pelo PMDB deixam claro o aumento da ala formada por ex-arenistas e ex-emedebistas moderados nas fileiras do partido a partir de 1982, o que desfigurou sua imagem relativamente homogênea no momento de sua fundação. Os dados evidenciam também um processo de "inchaço" do PMDB, compreendido como a entrada de quadros não comprometidos com a sua proposta programática inicial (no caso, os ex-arenistas) de 1982 em diante, diferentemente do que argumentam alguns autores na literatura sobre os partidos brasileiros, que apontam que tal inchaço passou a ocorrer apenas a partir do momento em que o partido chegou ao Poder Executivo Nacional (como Couto, 1997, p. 35; Sadek, 1989b, p. 113 e Lamounier, 1989, p. 52).

Com relação aos indicadores a respeito da nova bancada do PMDB no Senado Federal, notamos o quanto a incorporação trouxe para o PMDB uma parcela de quadros ex-arenistas. Dos seis ex- 
pepistas que passaram a compor a bancada do PMDB naquela Casa após as eleições de 1982, nada menos que cinco tiveram passagem pela Arena em algum momento de sua trajetória política (três dos quais eram senadores "biônicos”, nomeados pelo Regime). Assim, a nova bancada do PMDB no Senado, composta por 21 senadores, passou a ter $7(33 \%)$ políticos que haviam passado pela Arena ${ }^{176}$.

Tabela 21. Filiação partidária pregressa dos ex-pepistas que compõem a bancada do PMDB no Senado Federal após as eleições de 1982

\begin{tabular}{l|c|c|c}
\hline \hline \multicolumn{4}{|c}{ Filiação partidária anterior } \\
\hline \hline & MDB & ARENA & Total \\
\hline Ex-pepistas & 1 & 5 & 6 \\
\hline \hline
\end{tabular}

Fontes: elaboração própria a partir de informações fornecidas pelo Serviço de Informação ao Cidadão do Senado Federal e pelo Centro de Pesquisa e Documentação de História Contemporânea do Brasil (CPDOC/FGV).

A comparação entre a filiação partidária pregressa da bancada peemedebista no Senado evidencia o início do processo de "inchaço" do PMDB. Dos 22 Senadores que participaram da fundação do PMDB, eram 20 (91\%) os ex-filiados ao MDB e apenas $2(9 \%)$ os ex-filiados à Arena. Após as eleições de 1982, a bancada do PMDB naquela Casa passaria a ser composta por 21 Senadores, mas contando a partir de então com 7 (33,3\%) ex-filiados à Arena frente aos $14(66,7 \%)$ ex-filiados ao MDB.

Tabela 22. Evolução do número de ex-filiados à Arena e ao MDB na bancada do PMDB do Senado Federal em 1980 e após as eleições de 1982

\begin{tabular}{l|c|c|c|c}
\hline \hline & \multicolumn{2}{|c|}{1980} & \multicolumn{2}{c}{1982} \\
\hline \hline MDB & $\mathrm{N}$ & $\%$ do total & $\mathrm{N}$ & $\%$ do total \\
\hline Arena & 20 & $91 \%$ & 14 & $66,7 \%$ \\
\hline $\begin{array}{l}\text { Tamanho } \\
\text { da bancada }\end{array}$ & 22 & $100 \%$ & 21 & $100 \%$ \\
\hline \hline
\end{tabular}

\footnotetext{
${ }^{176}$ As duas exceções de senadores arenistas no PMDB e que não foram do PP são o Senador Marcelo Miranda Soares, do Mato Grosso do Sul, que ingressou no PMDB imediatamente após sair da Arena, e o Senador Severo Gomes, que havia se transferido ao MDB poucos meses antes da extinção daquele partido.
} 
Fontes: Schmitt (2000, p. 51) para os dados de 1980 e elaboração própria a partir de informações fornecidas pelo Serviço de Informação ao cidadão do Senado Federal, Centro de Pesquisa e Documentação de História Contemporânea do Brasil (CPDOC/FGV) e pelo Repositório de Dados eleitorais do TSE para os dados de 1982.

Com relação aos eleitos para a Câmara dos Deputados, notamos que, dentre os duzentos deputados federais eleitos pelo PMDB em 1982, 32 (16\%) haviam sido filiados ao PP durante sua curta experiência partidária centrista. Ou seja, 32 parlamentares da bancada do PMDB na Câmara fizeram parte de uma experiência partidária que possuía uma proposta de centro, portanto, diferente da sua. Essa bancada de ex-pepistas dentro do PMDB era formada por 13 políticos que haviam feito parte da Arena durante o período de 1966 a 1979, e por 19 ex-emedebistas, representantes da ala dos "moderados" daquele extinto partido.

Tabela 23. Filiação partidária pregressa dos ex-pepistas eleitos para a Câmara dos Deputados pelo PMDB em 1982

\begin{tabular}{l|c|c|c}
\hline \hline & \multicolumn{2}{|c|}{$\begin{array}{c}\text { Filiação partidária } \\
\text { anterior }\end{array}$} & \\
\hline \hline & MDB & ARENA & Total \\
\hline Ex-pepistas & 19 & 13 & 32 \\
\hline \hline
\end{tabular}

Fontes: elaboração própria a partir de informações fornecidas pelo Centro de Documentação e Informação da Câmara dos Deputados (CEDI), pelo Centro de Pesquisa e Documentação de História Contemporânea do Brasil (CPDOC/FGV) e pelo Repositório de Dados eleitorais do TSE.

Levando em conta a bancada do PMDB na Câmara como um todo, notamos que uma parcela dos ex-arenistas que passam a fazer parte da sua bancada não ingressaram no partido por meio da incorporação do PP. Dos 200 deputados eleitos pela legenda em 1982, 32 (16\%) haviam passado pela Arena em algum momento no período pré-1979, e desses, $13(40,6 \%)$ eram os ex-pepistas. Ou seja, com relação à Câmara, a incorporação do PP representou uma parte da entrada de quadros ex-arenistas no PMDB, ainda que os ex-pepistas representem quase a metade desse bloco. Porém, devese destacar que o aumento da heterogeneidade interna do partido não se restringe apenas à entrada dos ex-arenistas. Deve-se lembrar 
que a incorporação trouxe também para o PMDB uma parcela importante de ex-emedebistas moderados, que não fizeram parte do partido nos seus primeiros anos de formação, e que tem suas fileiras reforçadas pelo ingresso dos ex-arenistas.

Analisando de maneira comparativa a filiação partidária pregressa daqueles que compunham a bancada do PMDB na Câmara no momento de sua fundação com a filiação pregressa dos eleitos em 1982, torna-se patente o aumento da heterogeneidade interna do partido em seus primeiros anos. Dos 115 deputados que participaram de sua Fundação, 109 (94,78\%) eram filiados ao MDB e apenas $6(5,22 \%)$ eram filiados à Arena. Após as eleições de 1982, em uma bancada composta por 200 Deputados, 148 (74\%) eram antigos filiados ao MDB, 32 (16\%) antigos filiados à Arena, e 20 (10\%) não haviam sido filiados a nenhum desses dois partidos, seja porque estreavam na política, seja porque retornavam à política partidária após um período de cassação dos direitos políticos. Estes indicadores nos mostram uma nova evidência sobre a desfiguração pela qual o PMDB passou de 1979 a 1982.

Tabela 24. Evolução do número de ex-filiados à Arena e ao MDB na bancada do PMDB na Câmara dos Deputados em 1980 e em 1982

\begin{tabular}{l|c|c|c|c}
\hline \hline & \multicolumn{2}{|c|}{1980} & \multicolumn{2}{c}{1982} \\
\hline \hline MDB & $\mathrm{N}$ & $\%$ do total & $\mathrm{N}$ & $\%$ do total \\
\hline Arena & 109 & $94,78 \%$ & 148 & $74 \%$ \\
\hline $\begin{array}{l}\text { Nenhuma } \\
\text { filiação } \\
\text { anterior }\end{array}$ & 6 & $5,22 \%$ & 32 & $16 \%$ \\
\hline $\begin{array}{l}\text { Tamanho da } \\
\text { bancada }\end{array}$ & 115 & $100 \%$ & 200 & $10 \%$ \\
\hline \hline
\end{tabular}

Fontes: Schmitt (2000, p. 51) para os dados de 1980 e elaboração própria a partir de informações fornecidas pelo Centro de Documentação e Informação da Câmara dos Deputados (CEDI), pelo Centro de Pesquisa e Documentação de História Contemporânea do Brasil (CPDOC/FGV) e pelo Repositório de Dados eleitorais do TSE para os dados de 1982 . 
Nota-se, através desses dados, que houve um processo de desfiguração do PMDB, impulsionado pela incorporação do Partido Popular no início de 1982. Após as eleições desse ano, o PMDB teve sua bancada aumentada em comparação com o momento de sua fundação na Câmara dos Deputados e manteve a sua força no Senado, o que favoreceria o partido na futura disputa no Colégio Eleitoral, em 1985. Mas, ao mesmo tempo, triplicou a proporção de ex-arenistas nas bancadas da Câmara e do Senado.

Evidencia-se assim que o processo de incorporação do PP não foi uma "reincorporação", como apontaram alguns autores (Fleischer, 1988a, p. 79; Marques e Fleishcer, 1998 p. 16). A ideia de "reincorporação" se restringe apenas aos políticos pepistas que formavam a ala moderada do extinto MDB e que naquele momento passaram ao seu sucessor, o PMDB. O que os autores não notaram foi que a entrada dos quadros pepistas no PMDB trouxe no seu bojo, como uma espécie de "Cavalo de Tróia", uma parcela de políticos ex-arenistas, que diminuem o caráter oposicionista que o PMDB procurava construir desde sua fundação.

Junto com o aumento de sua ala moderada, ampliada pela incorporação de quadros ex-arenistas (que até pouco tempo antes estavam comprometidos com o Regime) e ex-emedebistas moderados, que fizeram parte do PP, o PMDB passava a ter, a partir de então, uma nova heterogeneidade interna, distinta daquela do MDB no momento de sua extinção, e também distinta daquela composição mais homogênea que o partido havia adquirido na fundação. 


\section{Considerações finais}

O presente trabalho buscou explorar as mudanças na heterogeneidade interna pelas quais o PMDB passou desde sua fundação, em 1979, até a incorporação do Partido Popular, em 1982. Foi possível concluir que essa incorporação teve consequências importantes para a composição interna do PMDB. A análise que levou a essa conclusão fez uso, principalmente, de dois indicadores empíricos principais: a composição dos dois principais órgãos de direção do PMDB, a saber, o seu Diretório Nacional e a sua Executiva Nacional, e as mudanças, em relação ao histórico de filiação partidária, dos eleitos pelo partido para o Congresso Nacional, antes e depois das eleições de 1982.

O primeiro passo para a verificação da hipótese consistiu em reconstruir o processo de formação inicial do PMDB (ou de refundação do MDB), um esforço inédito na literatura sobre o partido.

No Capítulo 2, foi visto que na passagem do bipartidarismo para o pluripartidarismo o PMDB se tornou o principal sucedâneo do MDB, mas parte dos quadros do extinto partido se transferiu para outras agremiações que surgiram. Dessa forma, moderados do MDB e liberais da Arena fundaram um partido com o intuito de ocupar o centro do espectro partidário, o Partido Popular (PP), como visto no Capítulo 3. Ao mesmo tempo, um bloco de “adesistas" do antigo MDB passou diretamente à base parlamentar do partido de sustentação do Regime, para fundar com parte dos egressos da extinta Arena o Partido Democrático Social (PDS).

Ademais, outros três partidos surgiram naquele momento. Lideranças do movimento sindical, estudantil e intelectuais iniciaram o processo de construção de um novo partido político "de baixo pra cima", dando origem ao Partido dos Trabalhadores (PT), 
algo que não estava nos planos do Regime. Ao mesmo tempo, Ivete Vargas e outras lideranças políticas de perfil mais personalista (como Jânio Quadros em São Paulo e Sandra Cavalcanti no Rio de Janeiro) buscaram construir um novo Partido Trabalhista Brasileiro (PTB), retomando uma mágica sigla do período anterior ao Regime Militar. Por sua vez, Leonel Brizola, após retornar do exílio, também procurou reconstruir a mítica trabalhista em torno de um novo partido, fundando o Partido Democrático Trabalhista (PDT), após perder a disputa pela histórica sigla para o grupo liderado por Ivete Vargas.

Verifica-se que, naquele momento de transição do sistema partidário, a maior parte dos quadros do extinto MDB que não seguiu para o PMDB seguiu para o PP e o PDS, e que os outros partidos mais claramente identificados com a oposição (PT e PDT) conseguiram sugar poucos quadros desse extinto partido. O PMDB surgiu, assim, com uma composição interna mais homogênea que seu predecessor, e que levou Kinzo (1988, p. 210) a concluir que o partido surgia com uma composição mais de centro-esquerda.

Porém, no início de 1982 , esse cenário passou a mudar.

Como visto no Capítulo 3, após incorporar o Partido Popular o PMDB traz para o seu interior uma nova ala de políticos, formada por antigos integrantes da "ala moderada" do extinto MDB e por figuras que pouco tempo antes estavam comprometidas com o Regime Militar, aumentando a heterogeneidade interna do partido. Não se tratou de uma mera "reincorporação", como apontaram alguns jornais e alguns autores (Fleischer, 1988a, p. 79; Marques e Fleishcer, 1998 p. 16), e os dados assim o comprovam. No momento de sua fundação o PMDB possuía em seu Diretório Nacional $61(88,4 \%)$ ex-filiados ao MDB, frente a $8(11,6 \%)$ políticos que tiveram passagem anterior pela Arena. Com a incorporação do PP, o número de ex-filiados ao MDB no Diretório cai para $53(76,8 \%)$ frente a $16(23,2 \%)$ políticos que tiveram 
filiação à Arena. Assim, a ideia de uma "reincorporação" se restringe apenas aos ex-emedebistas moderados que retornavam ao seio da oposição para recompor sua ala moderada.

Mudou também, naquele momento, o caráter da composição da Executiva Nacional do Partido, que perdeu dois dos "autênticos" como vogais (Alencar Furtado e Fernando Cunha), para dar lugar a dois ex-arenistas (Mendes Canale e Aloisio Alves), além de políticos moderados que assumiram a vice-presidência (Tancredo Neves) e a $1^{a}$. Secretaria (Miro Teixeira). A partir daquele momento, antigos filiados ao MDB que tanto haviam lutado contra o Pacote de Abril, em 1977, passaram a ver no Diretório Nacional do PMDB alguns dos senadores biônicos nomeados justamente por meio daquele Pacote.

A incorporação também transformou a realidade do PMDB em alguns Estados. No Rio de Janeiro, o partido passou subitamente de oposição a governo (tendo seu Diretório Regional se dividido com o ingresso dos provenientes do PP) e, apesar de passar a ter uma enorme rede de diretórios, teria dificuldades em construir uma candidatura de imagem "oposicionista" ao Regime, sendo Governo do Estado. Por sua vez, com relação ao PMDB em Minas Gerais, na prática, o partido acabou por ser incorporado ao PP, pois o seu Diretório Regional passou a ter mais ex-pepistas do que peemedebistas em sua composição, o que se refletiu na escolha de Tancredo Neves como candidato ao cargo de governador do Estado em 1982.

Por fim, no Capítulo 4, foi apresentado outro indicador empírico por meio do qual foi possível verificar a nova composição interna do PMDB, e patentear mais uma vez o aumento de sua heterogeneidade após a incorporação do PP. Por meio de uma análise de sua bancada eleita para o Congresso Nacional em 1982 , verificamos o histórico de filiação partidária de seus representantes naquela Casa e a comparamos com a primeira 
bancada do partido, no momento de sua fundação. Verificamos que a bancada do PMDB pré-fusão na Câmara dos Deputados contava com apenas 6 arenistas $(5,22 \%)$. Após a eleição de 1982 ela passou a contar com 32 (16\%). No Senado, a bancada de ex-arenistas passou de 2 para 7 (passando de $9 \%$ para $33 \%$ do total), alguns dos quais haviam sido senadores biônicos nomeados pelo Regime Militar poucos anos antes.

Tendo em vista os aspectos explorados, numa análise retrospectiva do recorte histórico de 1979 a 1982, nota-se que o partido se tornou mais heterogêneo em comparação com o momento de sua fundação quando houve a incorporação do PP. A partir daí teve início o inchaço do partido, ou o seu "processo de deformação mórbida" (Benevides, 1986), com a entrada de políticos que pouco tempo antes estavam comprometidos com o regime militar. Esse "inchaço" teve repercussões futuras na composição do partido, resultando no que ele é hoje, mas essa é uma análise que excede os limites desta pesquisa. 


\section{ANEXO 1}

\section{MANIFESTO DOS FUNDADORES DO PMDB À NAÇÃO}

A luta pela democracia no Brasil inicia, hoje, mais uma etapa com a fundação do Partido do Movimento Democrático Brasileiro. Com a extinção do MDB, o regime autoritário tomou a mais violenta de uma longa série de medidas que se assemelham todas no fundamental. Sempre que as oposições, fiéis à vontade popular, ameaçaram o poder discricionário e se constituíram em alternativa de governo, o sistema, mudando casuisticamente as regras vigentes, procurou impedir essa alternância. Agora, perpetra-se, repete-se e perpetua-se o golpe de estado com flagrante ofensa aos princípios constitucionais.

Enquanto o governo preserva o controle sobre o aparelho do Estado através de expedientes que esvaziam de conteúdo real as instituições republicanas, tornando-as verdadeira farsa para deturpar a vontade popular, procura, ainda que de maneira confusa e vacilante, assegurar um crescimento econômico, afastando as maiorias populares da riqueza e do poder. Este, sustentado pela aliança entre a burocracia estatal, as classes ricas e as empresas multinacionais, propõe-se a manter inalterada a situação social e utiliza a retórica de que o país se transformou numa potência emergente. As forças dominantes, embora acenando com a ampliação do acesso ao consumo, na verdade não sacrifica o luxo de poucos para abolir a miséria de muitos. Exige que as formas limitadas do pluralismo político tolerado se desenvolvam dentro dos estreitos, porém variáveis limites impostos pelos governantes para que a maioria não se torne militante e mobilizada. Nesse sentido procura reduzir os cidadãos a uma massa inerme e obediente, construir a naçãopotência sobre a base das desigualdades sociais e regionais existentes. E não hesita em usar todas as armas do golpismo pseudo-constitucional para impedir que a luta da oposição, dentro ou fora dos partidos, frustre essas intenções liberticidas.

Bem poderiam as oposições sentir desalento ao ver tantas vezes mudadas as condições da vida política para sofismar as manifestações e fugir às consequências do repúdio popular. O Movimento Democrático Brasileiro foi o grande instrumento das oposições. Cresceu apesar de todas as adversidades e todas as descrenças, até tornar-se, pelo voto, representante inequívoco da maioria da Nação. Superou todos os casuísmos com que se procurou detê-lo, até que o governo teve que recorrer ao expediente fascista e final da dissolução partidária. 
Os fundadores do PMDB lembram à Nação que a fé e a esperança dos brasileiros insubmissos fizeram de cada um desses motivos de desalento uma oportunidade para um novo avanço contra o governo, o regime discricionário e a ordem social que o regime e o governo querem manter. E declaram que a maior truculência de todas - a dissolução coercitiva do Movimento Democrático Brasileiro - será transformada, pela mesma esperança e pela mesma fé, de um número cada vez maior de brasileiros revoltados, no maior de todos os avanços: a construção do Partido do Movimento Democrático Brasileiro.

A nação não esquece que cada arbitrariedade do regime permitiu sempre uma definição mais nítida das forças oposicionistas. Enquanto alguns, nominalmente da oposição, fraquejavam e transigiam, outros, muitas vezes vindo das bases partidárias e dos novos movimentos sindicais e comunitários, engajavam-se na luta. Agora, esse mesmo avanço dar-se-á em dimensão maior. O PMDB congregará todas as correntes verdadeiramente populares e democráticas. Não servirá de instrumento aos que colaboram, direta ou indiretamente, com o governo, nem aos que não estejam realmente dispostos a participar de uma obra de mobilização popular. E ganhará novos quadros que, até hoje, permanecem afastados da política partidária por não identificá-la como veículo adequado aos movimentos de base.

A nação não esquece que o combate ao autoritarismo ensinou a todos que a eficácia da resistência contra um regime que usa as próprias formas constitucionais como armas do arbítrio, dependeu sempre da capacidade de transformar a política partidária num meio de organização e conscientização em profundidade. E, como tal, começar superando o imenso abismo entre a política das cúpulas e a política das bases, entre as aspirações das minorias marginalizadas.

Portanto, o PMDB deseja ser o grande instrumento de aprofundamento da resistência democrática e será sobretudo o estuário de todas as correntes do pensamento livre, inconformados com a tutela a que a Nação esta submetida. Haverá de romper cada vez mais o círculo fechado da política das elites e integrando a atividade partidária e parlamentar numa tarefa maior de pregação e militância. Tarefa que há de ser executada não só no âmbito parlamentar, mas em todos os lugares onde os brasileiros moram e trabalham e em íntima ligação com os movimentos sindicais e comunitários.

O PMDB será o caminho das oposições que compreendam que a luta contra o autoritarismo há de ter o seu desfecho não apenas na reconstitucionalização do Estado, mas na democratização da sociedade, através de um engajamento cada vez mais combativo e organizado de 
todos os brasileiros e em especial das camadas populares e da classe média. Os compromissos que norteiam o nosso partido e a concepção de sua prática política são o fruto de um duro aprendizado, ganho no curso de uma resistência a que se incorporam lideranças dos movimentos sociais emergentes. As reivindicações definidoras do partido nos campos político e econômico-social serão formuladas à luz dessa experiência histórica concreta. E, se o partido terá por objeto imediato opor-se ao autoritarismo, perfigurará, através da própria maneira de fazer oposição, as linhas mestras de uma sociedade e uma cultura democratizadas, emancipadas não só das desigualdades cruas, como também dos paternalismos sutis.

O Partido do Movimento Democrático Brasileiro:

1) Prosseguirá e intensificará a luta travada pelo Movimento Democrático Brasileiro em prol das grandes teses democráticas: manutenção do calendário eleitoral, eleições diretas em todos os níveis, defesa da autonomia dos Municípios e fortalecimento da Federação, democratização do ensino, anistia ampla, geral e irrestrita, liberdade de informação, restauração dos poderes do Congresso e convocação de uma Assembleia Nacional Constituinte.

2) Surgirá disposto a uma política de organização e de mobilização, sobretudo frente aos conflitos, sempre pela via de militância pacífica e democrática.

3) Terá como tarefa fazer uma oposição confiável ao povo, não aos detentores do poder.

4) Dará primazia à obra de mobilização popular, com o fortalecimento das bases partidárias e o avanço e aprofundamento da auto-organização sindical e comunitária dos setores não organizados do povo.

5) Lutará pelas garantias econômicas e jurídicas - a erradicação da miséria e a liberdade de organização - que permitam a execução da tarefa mobilizadora e assegurem a autonomia associativa; defenderá os direitos dos trabalhadores rurais e urbanos, a autonomia e a liberdade dos sindicatos perante o Estado e os empresários, a instituição do delegado sindical nos locais de trabalho, a negociação direta entre patrões e empregados e o direito de greve.

6) Adotará uma forma de organização interna que afirme o princípio do colegiado efetivo na sua direção, que estabeleça um debate participativo e permanente sobre o programa e a ação partidária e que engaje, em todos os níveis, os quadros não parlamentares e as lideranças dos movimentos sociais em formação. 
7) Propugnará um programa que aponte o caminho para a democratização das formas de poder, a produção e a erradicação da miséria, sem cair em fórmulas pré concebidas, nem se satisfazer com a mera redistribuição do consumo.

8) Procurará fazer-se o grande instrumento de uma força majoritária de transformação social que se contraponha não só ao estado autocrático e à ordem econômica iníqua, como também a uma cultura paternalista e autoritária: um partido combativo e popular, que fale uma linguagem e desenvolva uma prática aberta às classes médias, ao operariado organizado e às massas miseráveis e marginalizadas.

9) Exigirá que a integração da nação - eliminados os abismos entre classes e regiões - se realize por uma política de acumulação e investimento que associe os centros decisórios do Estado às necessidades e à participação dos assalariados e dos pequenos e médios proprietários, em vez de associá-los aos grandes oligopólios nacionais e estrangeiros, que participam do sistema da miséria e da desnacionalização. Lutará pela defesa intransigente dos nossos recursos naturais, hoje explorados de forma predatória e entreguista por grupos internacionais.

10) Proporá frente democrática com outros partidos de oposição que vierem a surgir, respeitando os compromissos partidários de cada um e lutando por um pluripartidarismo absolutamente livre da tutela estatal e da influência do poder econômico.

Buscamos, na fidelidade a esses compromissos, uma sociedade que, através de sua batalha contra o Estado autocrático, seja capaz de organizar-se para praticar a democracia não apenas no governo, mas em todas as instituições onde os homens exercem poder uns sobre os outros. Uma sociedade em que a estrutura constitucional discipline o poder pela rápida resolução dos impasses e pela multiplicação das formas de representação e consulta popular. Uma sociedade em que a eliminação da miséria e das grandes desigualdades seja condição e consequência da militância partidária, sindical e comunitária de base. Uma sociedade, portanto, em que a justa redistribuição do consumo se faça simultaneamente com o fortalecimento da auto-organização coletiva e com a multiplicação das formas de participação popular no poder. Uma sociedade em que se estabeleça o controle político democratizado sobre os fluxos básicos de investimento para assegurar que as diretrizes do processo de acumulação obedeçam as decisões majoritárias. Isso para impedir que a retração dos investimentos subverta os planos reformadores; para orientar o perfil da produção e do consumo, bem como a relação entre indústria e agricultura e entre a economia brasileira e a estrangeira. Tudo para servir às necessidades populares. Mas, ao 
mesmo tempo, uma sociedade em que se promovam o poder decisório dos operários sobre a organização e a hierarquia do trabalho e os vínculos cooperativistas entre pequenos e médios proprietários, nas cidades e nos campos. Uma sociedade que aproveite a indefinição política de suas classes como oportunidade para a execução de um projeto de democracia mais mobilizante e portanto mais capaz de penetrar o sistema produtivo e a vida quotidiana. Uma sociedade, por is so mesmo, que multiplique tanto quanto possível, os mecanismos de polêmica e deliberação que permitam aos homens exercer sua liberdade coletiva na reconstrução da vida social.

Os fundadores do PMDB têm consciência da imensa dificuldade do projeto de militância e mobilização que os anima. Mas sabem que sem uma prática intensa de organização popular dificilmente se conseguirá atingir sequer o grau de democracia representativa e de redistribuição da renda e da riqueza que distingue as democracias consolidadas. Sem essa mobilização, o povo estará impotente diante da máquina do Estado ou disponível e lideranças demagógicas e agitações superficiais que só provocam novas reações autoritárias.

As desigualdades de riqueza de renda, bem como de acesso à segurança, às oportunidades e ao poder no sistema produtivo, são tamanhas e tão enraizadas no Brasil que só cederão a uma força popular combativa e organizada.

Os fundadores do PMDB comprometem-se perante a Nação a construir um partido que seja, pelos seus métodos de atividade e pela sua estrutura interna, um prenúncio da ordem social que ele advoga para o País. Assumem esse compromisso conscientes dos perigos e obstáculos que enfrentam: a dificuldade de executar qualquer obra mobilizadora num regime de arbítrio sempre disposto às manipulações e perversões institucionais ao capricho de suas conveniências a enorme distância que ainda separa a militância partidária e a experiência quotidiana dos brasileiros humildes; o despreparo, resultante da descontinuidade democrática, para penoso trabalho de estruturação partidária, de luta em defesa da auto-organização sindical e comunitária e de participação nos conflitos sociais.

A constância e a inconformidade de muitos transformaram um partido indefeso, numa organização vigorosa que o regime teve que extinguir para poder, por mais algum tempo, sobreviver. A constância e inconformidade transformarão o sucessor desse partido num movimento que emancipará o País não só do governo, mas do regime despótico, não só do regime, mas da ordem social vigente.

Dezembro de 1979 
Senadores: Adalberto Sena (AC); Evandro Carreira (AM); Mauro Benevides (CE); Agenor Maria (RN); Cunha Lima e Humberto Lucena (PB); Marcos Freire (PE); Teotônio Vilela (AL); Nelson Carneiro e Roberto Saturnino (RJ); Itamar Franco (MG); Franco Montoro e Orestes Quércia (SP); Henrique Santillo e Lázaro Barboza (GO); José Richa e Leite Chaves (PR); Jaison Barreto (SC); Paulo Brossard e Pedro Simon (RS).

Deputados: ACRE - Aluízio Bezerra, Geraldo Fleming, Nabor Júnior; AMAZONAS - Mário Frota; PARÀ - Jader Barbalho; CEARÁ - Iranildo Pereira, Paes de Andrade; PARAÍBA - Arnaldo Lafayette, Marcondes Gadelha, Octacílio Queiroz; PERNAMBUCO - Cristina Tavares, Fernando Coelho, Fernando Lyra, José Carlos Vasconcelos, Marcus Cunha, Roberto Freire; ALAGOAS - José Costa, Mendonça Neto, Murilo Mendes; SERGIPE - Jackson Barreto; BAHIA - Elquisson Soares, Francisco Pinto, Hilderico Oliveira, Jorge Viana, Marcelo Cordeiro, Raimundo Urbano, Roque Aras; ESPÍRITO SANTO - Gerson Camata, Mário Moreira, Max Mauro; RIO DE JANEIRO - Celso Peçanha, Délio dos Santos, Edson Khair, Felippe Penna, Jorge Gama, José Maria de Carvalho, Marcelo Cerqueira, Modesto da Silveira, Oswaldo Lima, Paulo Rattes, Walter Silva; MINAS GERAIS - Edgard Amorim, Fued Dib, João Herculino, Júnia Marise, Pimenta da Veiga, Ronan Tito, Tarcísio Delgado; SÃO PAULO - Airton Sandoval, Alberto Goldman, Antônio Russo, Audálio Dantas, Aurélio Peres, Cardoso Alves, Carlos Nelson, Del Bosco Amaral, Flávio Chaves, Freitas Nobre, Horácio Ortiz, Israel Dias Novaes, Mário Hato, Octacílio Almeida, Pacheco Chaves, Ralph Biasi, Ruy Côdo, Samir Achôa, Santilli Sobrinho, Tidei de Lima, Ulysses Guimarães, Valter Garcia; GOIÁS - Adhemar Santillo, Fernando Cunha, Iran Saraiva, Iturival Nascimento, José Freire, Paulo Borges; MATO GROSSO - Carlos Bezerra, Gilson de Barros; PARANÁ - Álvaro Dias, Amadeu Geara, Ernesto Dall'Oglio, Euclides Scalco, Heitor Alencar Furtado, Hélio Duque, Maurício Fruet, Nivaldo Kruger, Olivir Gabardo, Osvaldo Macedo, Paulo Marques, Sebastião Rodrigues Júnior; SANTA CATARINA - Ernesto de Marco, Francisco Libardoni, Juarez Furtado, Pedro Ivo, Walmor de Luca; RIO GRANDE DO SUL - Aldo Fagundes, Cardoso Fregapani, Carlos Santos, Eloar Guazzelli, Harry Sauer, Jairo Brum, João Gilberto, Jorge Uequed, Júlio Costamilan, Odacir Klein, Rosa Flores, Waldir Walter; RONDÔNIA - Jerônimo Santana.

Não-Parlamentares: Fernando Gasparian, Mauro Borges Teixeira, Jarbas de Andrade Vasconcelos, José Alencar Furtado, José Carlos Mesquita Teixeira, Miguel Arraes de Alencar, Renato Bayma Archer da Silva, Roberto Mangabeira Unger, Pedro Moreno Gondin, Wilson Barbosa Martins, José Serra, Djacir Cavalcante de Arruda, Mário Covas Júnior, 
Amaury de Oliveira e Silva, Raphael de Almeida Magalhães, Almino Monteiro Alvarez Affonso, Paulo de Tarso Santos, Fernando Henrique Cardoso, Severo Fagundes Gomes, Djalma Marinho Muniz Falcão, Milton Reis, Marcos Wellington de Castro Tito. 


\section{ANEXO 2}

Composição do Diretório Nacional do PMDB eleito em sua primeira Convenção Nacional (07/12/1980):

Adalberto Sena

Agenor Maia*

Aldo Fagundes

Alencar Furtado

Armando Temperani Pereira

Aurélio Peres

Celso Gabriel de Rezende Passos

Celso Peçanha

Chagas Rodrigues

Cunha Lima

Edgard Amorim

Edgar da Mata Machado

Euclides Scalco

Evandro Carreira*

Fernando Coelho

Fernando Cunha

Fernando Lyra

Francisco Libardoni

Francisco Pinto

Franco Montoro

Freitas Nobre

Gerson Camata*

Gilson de Barros*

Hélio Duque

Humberto Lucena

Henrique Santillo

Iranildo Pereira

Jader Barbalho

Jackson Barreto

Jaison Barreto

Jarbas Vasconcelos

Jerônimo Santana

João Evangelista Pereira de Melo

José Carlos Teixeira

José Richa

Lázaro Barboza

Leite Chaves

Léo de Almeida Neves 
Luiz Mariano Paes de Carvalho Filho

Mário Covas

Mário Moreira

Mário Frota

Marcos Freire

Mauro Benevides

Mauro Borges Teixeira

Marcelo Cerqueira

Miguel Arraes

Nabor Júnior

Orestes Quércia

Octacílio Queiroz

Paulo Brossard

Paulo Rattes

Pedro Simon

Raphael de Almeida Magalhães*

Raimundo Azevedo Costa

Renato Archer

Roberto Cardoso Alves*

Rômulo de Almeida

Severo Gomes*

Siegfried Emmanuel Heuser

Simão da Cunha Pereira

Tarcísio Delgado

Teotônio Vilela*

Tidei de Lima

Valdice Macedo Nobre

Waldir Pires

Wilson Martins

Ulysses Guimarães

Retirado do Pedido de Registro Definitivo - RGP no 38 - Resolução/TSE $\mathrm{n}^{\mathrm{o}} 11.042$

*Políticos com passagem pela Arena 
Reprodução da nota pública emitida pelos representantes de PP, PMDB, PTB e PT, após reunião realizada em Julho de 1981, na qual definem quais serão os objetivos das oposições quanto à sua atuação conjunta no semestre posterior.

\section{"Queremos eleição livre"}

A declaraçato assinada pelos prestdentes do PMDB, Ulysaes Ouimarkew; do Partido Popular, Tancredo Neves; do Partido dos Trabalhadores, Luis I minclo da Bliva; e pela ex-deputada Ivete Vargas, pelo PTB, na integra, a seguinte:

"A siturcho economica e social do Brasil atinge gravidade sem precedentea em nosas historia. A taxa de inflischio nunca cresceu tanto, divida externa nunca fol tso elevada e of indices de desemprego nunca atormentaram tanto os trabalhadores e assalarlados que consttuem a maloria do povo.

O governo vem - we mostrando Incapez de tomar medidas objetivas que tirem o Pafs de depreasto economica. Alem dis. $B$, tem-se mortrado impotente, como se ví pelo episodilo do Rlocentro e pela indeftniçlo das leis eleitorals, de rewolver - impanse polittco. Preocupado que eat em manter o poder aem sustentacho legttime na sociedade, taltum-the condictes para conduzir a democratieg clo do Paia.

Em iace deasa eltuacilo, os partidos de oposiçlo, reunidos neste primeiro en. contro em sho Paulo, respeltada a indivi. dualldede de cada um, manifestam sua diaponiclio de atuar em confunto para aseegurer a particlpaçlo do povo no en. caminhamento do processo de democrathestio. Preocupam-se nilo so em oomba. ver o caruiamo elettonal que a Nactlo it rejeltou, mas tambem em abrtr perspect. va de um regtme democratuco estavei, aob - vigtnci de uma Constutulfio emanida direta ivremente da vontade do povo, dotado da capacidade de atender as demandas da socledade.

Asaim, as partidos de oposiçato dirtrem-a A Nacto para propor a unifio de todos, consciente - eficar, em tomo dos eeguintes objetivos:
Elelçoes diretas em todos oe niveta e restabejecimento das premogattvas do Congreaso;

Ledial cho eleitoral verdedeiramente democrattic que respelte a liberdade de orsanteraglo e funcionemento de pertidoa repreaentativo de todas as correntes do pensamento politico; eliminecllo dos dis. poeltivos antidemocritucos que restrin. erm a eleglbilidade dos clidndilos.

Revoegerto das ataral leta de Beru. manca Nacional - de Imprensa e demals instrumentos de excecllo, desattvando-te os organismos de represallo politica.

ixtenallo do diretio de voto sos annal. fabetos.

Oerantla de uma ortantractlo andical live da tutela do Eatado.

Gerantia do pleno exercíclo do direlto de greve.

Por uma politter de empreso que atenda a todos os setores amaniariados da sociedade.

Por uma politica fusta de distribul. clato de rendase

Por uma politica economica que eft. mine os privilégios concedidos as empresas de grande porte, is multinacionals e no caplital tinanceiro, vieando no fortaleetmento do mercado interno.

Democrattracilo do Poder Judiclarto, para torni-1o coestivel aos cldadisos. principalmente an de balxa renda, e, temberm, effelente, ripldo - eeruro na distribuighlo de Juatica.

Com vistan a estes objetivoe, os part. doa de opoedclato manifestam o seu propo. ilto de proeserutr, em novos encontros, na elisobraclio de um piano de atuactio em comum e, necentrio, de promove a mia completi unidedo de sclo, vieando - garnintio do wa preserseca, como parto lefiltima e esaencth, do proceses de do mocratiagito do Pals". 


\section{ANEXO 4}

Reprodução da nota pública emitida pelo Palácio do Planalto na qual o Presidente anuncia as medidas conhecidas como "Pacote de Novembro".

"Encaminhei ao Congresso Nacional projetos de lei dispondo sobre modificações na legislação eleitoral. Diante das dificuldades verificadas na tramitação desses projetos, autorizei negociações para que, mediante acordos, se editassem, desde logo, as alterações nas regras concernentes ao pleito eleitoral de 1982. As negociações não surtiram, porém, até aqui, quando iminente fim da sessão legislativa, o efeito desejado.

Diante do impasse criado, resolvi adotar, quando ao pleito de 1982, a seguinte decisão, que tem por fim não só resolver o problema institucional que o quadro político apresenta, como imprimir maior rigor às linhas estruturais do pluripartidarismo, consagrado pela Constituição Federal:

1 - O voto será vinculado em todas as eleições municipais, estaduais e federais, majoritárias ou proporcionais.

2- Será indeferido o registro da chapa em que não se inscreverem conjuntamente candidatos a todas as eleições.

3- O voto será dado, obrigatoriamente, em todos os casos, e sob pena de nulidade, aos candidatos de um só partido político.

4- A desistência da candidatura dependerá de pedido simultâneo do candidato e do partido. A desistência, tácita ou expressa, da candidatura a governador importará a anulação dos votos dados ao partido.

5 - A Justiça Eleitoral disporá quanto ao processo de votação.

6- Recomendo que o PDS feche a questão, na forma da lei, não só em torno dessa decisão - que, com suas regras complementares, será objeto de projeto de lei, a ser encaminhado ao Congresso Nacional, nos termos do art. 51, parágrafo 2, da Constituição, como também as proposições, em trânsito no Congresso, relativas as modificações na Lei de Inelegibilidades e criação do Estado de Rondônia."

Reproduzido a partir da Folha de S. Paulo - 26/11/1981, p.4 


\section{ANEXO 5}

Reprodução da nota pública emitida pela bancada da oposição no Senado em repúdio à divulgação do "Pacote de Novembro".

"As bancadas dos partidos de oposição do Senado, sob impacto da decisão do presidente da República, general João Batista de Oliveira Figueiredo, anunciando um rude golpe de caráter institucional destinado a impedir a livre manifestação popular nas eleições de 82, ao mesmo tempo que manifestam seu total repúdio à infeliz e lamentável decisão presidencial, em reunião conjunta resolveram:

1- Propor aos presidentes de todos os partidos de oposição a realização de uma imediata reunião objetivando:

a) Ampla campanha de mobilização popular em defesa do voto livre em conjunto com entidades representativas da sociedade civil;

b) A fusão das oposições num novo e grande partido, iniciando o processo com a designação de uma comissão interpartidária;

c) Obstrução total dos trabalhos parlamentares no Senado e na Câmara, no Congresso Nacional, nas Assembleias Legislativas e nas Câmaras Municipais, ressalvados os projetos de excepcional interesse público e popular, a critério das lideranças oposicionistas.

2- Iniciar desde logo a obstrução total dos trabalhos parlamentares no Senado Federal"

Retirado da Folha de S. Paulo, 26/11/1981, p. 5. 


\section{ANEXO 6}

Reprodução da nota pública emitida pelos líderes do Partido Popular na qual anunciam que levarão adiante a discussão em torno da proposta de incorporação.

\section{Da decepção à união}

"O Partido Popular (PP) é uma Idéla vitoriosa desde o momento de sua fundaça. Nâo há porque disfarcar a decepcáo que nos atinglu na hora diffcll em gue travávamos da peleja leal na delesa de principlos essenclais do estado de Direlto e do regime democrático.

Admitimos fossem sinceras as palavras gover namentals que davam por finda a triste experlencla autoritaria e anunclavam compromissos nocia autoritaria com do da democracla no Brasil.

Dedicamos mals de um ano de persistentes es. forcos na organizacto de um partido, que fugindo ao radicallsmo emocional das posicóes extremas, exprimisse, nesta fase de transiça, as melhores aspiraçes de transformacoes politicas, soclais e aconomicas, com a eflcácla necessárla para reor denar a vida constituclonal, ellminar as injusticas do sistema oconomico e Inserir nos beneficios do desenvolvimento as muitidoes excluidas das mintmas condicoles de bem-estar.

Nem o clima de indeflnicóes institucionals dellberadamente-mantido, apesar de todos os recla mos, nem a desenvoltura com que os beneficlárlos do arbitrio ameacavam parallsar e fazer retroceder a lenta e trópega caminhada, para preserva os Interesses ilicitos do Poder a qualquer preco, foram suflctentes para esgotar as nossas reservas de crenca na fldelldade do governo aos propositos relteradamente renovados. Até o momento em que a NacAo, aturdlda, viu o Congresso Nacional, receber, sob a pressio da guest 4 o fechada e do expediente do decurso de prazo, numa convocacá extraordinária, a imposicáo de votar uma refor. ma eleftoral que poe a nu dols objetivos antes pressentidos: o anunclado pluripartidarismo era apenas a formula de dividir as oposiçes para esmaga-las; o voto so seria llvre na medida em que no ameacacse pela vontade do povo, a posse do Poder por aqueles que o usufruem sem a aprovacao naclonal.
Éstes propósitos estao claramente definidos no chamado "pacote" eleitoral, posto sobre a cabeca do Poder Legislativo, numa atoarda de instnuacoes, ameacas, intimidacoes humilhantes $e$ desmorallzadoras.

Face a esta violéncla, e com o Intulto legitimo e exclusivo de resguardar, na defesa do voto popular, as aspiraçes de que nos fizemos interpretes. so hos restou, na precarledade do quadro legal vi gente, e em prazos imperativos que nao permitiram sequer a consuita ds bases municipals, a al. temativa de Incorporar a legenda do Partido Popular (PP), a do Partido do Movimento Democrático Brastleiro (PMDB), colocando, sobre nossas eventuals diferencas de programas e estrate glas o interesse malor de assegurar ao povo a oportunidade de fazer prevalecer a sua vontade sobre as condlclonamentos e pressoes aparentemente legals que lhe sto impostas.

mente legals que lho sao impostas. gal que nos é permitida face as eleicoles, os nossos compromissos com a democracla, com os anselos o as necessidades de reorganizacto instituclonal, de transformaculo paciflca das nossas estruturas. de transformacao pacirica das nossas estruturas. tos Insensatos e intitels entre ponderavels parcelas do povo e a armadura do Poder. Nao aceltamos que o Pals tenha que ser dirigido, por tempo indeterminado, por um so grupo de homens privl. leglados. Nem atue sela este o objetlvo da acio polltica guando a Naço se derronta com a anguspolltica quando a Nacao se derronta com a ang

Queremos, apenas, defender o espaco gue conguistamos, entre todos os sacrificios, cm nome da confance de nossos elettores, espalbados por mt. manes de municiplos braslleiros. E aguardar, liares de municiplos brasliciros, Es a fó em que com os restos quase essotados de nossa fé em que sor, a hora proprla om que se possam organizar e exprimir llvremente, no verdadelro pluripartida. rismo as tondenclas naturals da opiniao publica como fonte autentica em que se allimente o regime democrático."

Fonte: Folha de S. Paulo - 11/12/1981, p.4 


\section{ANEXO 7}

Diretório Nacional eleito pelo PMDB em sua Convenção Nacional Conjunta com os membros ingressantes do PP. Total de 46 peemedebistas e 23 ex-pepistas:

Affonso Camargo (PP-PR Senador biônico, ex-arenista)* Agenor Maria (RN, ex-arenista)

Aldo Fagundes (RS)

Alencar Furtado (PR)

Aluizio Alves (PP-RN Governador nomeado, ex-arenista)*

Antonio Morais (PP-CE, ex-emedebista)*

Armando Temperani Pereira (RS)

Aurélio Peres (SP)

Bento Gonçalves Filho (PP-MG ex-arenista)*

Celso Peçanha (RJ)

Chagas Rodrigues (PI)

Cid Sampaio (PP-PE, ex-arenista)*

Dejanir Dalpasquale (SC)

Edgard da Mata Machado (MG)

Edson Vidigal (PP-MA, ex-arenista)*

Euclides Scalco (PR)

Evandro Carreira (AM, ex-arenista)

Evelasio Vieira (PP-SC, ex-emedebista)*

Fernando Cunha (GO)

Fernando Lyra (PE)

Francisco Pinto (BA)

Gastão Muller (PP-MG Senador biônico, ex-arenista)*

Gilberto Mestrinho (PP-AM, ex-PTB Varguista)*

Gilson de Barros (MT)

Hélio Fernandes (PP-RJ, ex-emedebista)*

Henrique Santillo (GO)

Humberto Lucena (PB)

Iranildo Pereira (CE)

Jackson Barreto (SE)

Jader Barbalho (PA)

Jarbas Vasconcelos (PE)

Jerônimo Santana (RO)

João Agripino Filho (PP-PB, ex-arenista)*

João Evangelista Pereira de Melo (PP-RR)*

João Linhares (PP-SC, ex-arenista)*

João de Paiva Menezes (PP-PA, ex-emedebista)*

Leite Chaves (PR) 
Léo de Almeida Neves (PR)

Luiz Baptista (PP-ES, ex-emedebista)*

Marcelo Cerqueira (RJ)

Marcelo Miranda (MS)

Márcio Macedo (PP-RJ, ex-emedebista)*

Mário Covas (SP)

Mário Moreira (ES)

Mauro Benevides (CE)

Mendes Canale (PP-MT, ex-arenista)*

Miguel Arraes (PE)

Miro Teixeira (PP-RJ, ex-emedebista)*

Nabor Júnior (AC)

Octacílio Queiroz (PB)

Paulo Rattes (RJ)

Pedro Simon (RS)

Raimundo Azevedo Costa (AP)

Raphael Almeida Magalhães (RJ, ex-arenista)

Renato Archer (MA)

Roberto Cardoso Alves (SP, ex-arenista)

Roberto Figueira Santos (PP-BA Governador nomeado, ex-arenista)*

Roberto Herbster Gusmão (PP-SP, ex-emedebista)*

Ronan Tito (MG)

Sérgio Ferrara (PP-MG, ex-emedebista)*

Sérgio Murilo (PP-PE, ex-emedebista)*

Severo Gomes (SP, ex-arenista)

Tancredo Neves (PP-MG, ex-emedebista)*

Tarcísio Delgado (MG)

Teotônio Vilela (AL, ex-arenista)

Tidei de Lima (SP)

Ulysses Guimarães (SP)

Waldir Pires (BA)

Wilson Martins (MS)

*Ex-pepistas

Reproduzido a partir do Processo 6.371 - Resolução/TSE n 11.192 


\section{Bibliografia}

\section{Obras consultadas:}

ABREU, A. A. 2001. Dicionário Histórico-geográfico brasileiro, 1930-1983. Rio de Janeiro: Editora FGV;

ALMEIDA, L.C. 2004. PPB: origem e trajetória de um partido de direita no Brasil. Dissertação de mestrado, DCP - FFLCH - Universidade de São Paulo;

ALKMIN, A.C. 2014. De Brizola a Cabral. De Collor a Dilma: a geografia do voto no Rio de Janeiro de 1982 a 2010 [recurso eletrônico]. Rio de Janeiro: Ed. PUC-Rio;

AMARAL, O. E. do. 2011. Ainda conectado: o PT e seus vínculos com a sociedade. Opinião Pública, Campinas, v. 17, n. 1, p. 1-44;

2013. O que sabemos sobre a organização dos partidos políticos: uma avaliação de 100 anos de literatura. REVISTA DEBATES, Porto Alegre, v.7, n.2, p.11-32, maio-ago;

AMORIM NETO, O. 2000. Gabinetes presidenciais, ciclos eleitorais no Brasil. Dados Revista de Ciências Sociais, v.43, n.3;

2007. O Poder Executivo, centro de gravidade do sistema político brasileiro. In: CINTRA, A. O. \& AVELAR, L. O sistema político brasileiro: uma introdução. $2^{a}$ ed. São Paulo: Fundação Konrad Adenauer, Ed. Unesp, p.131-141;

ARAÚJO, C. E. P. de \& MACIEL, E. C. B. de A. 2002. A comissão de alto nível. História da Emenda Constitucional $\mathrm{n}^{\circ}$ 1, de 1969. In: A Constituição que não foi. História da Emenda Constitucional n ${ }^{o}$ 1, de 1969. Brasília: Senado Federal;

BENEVIDES, M. V. 1981. A UDN e o udenismo. Rio de Janeiro: Paz e Terra; . 1986. Ai que saudade do MDB!. Lua Nova vol.3 no.1 São Paulo

Junho;

CEDEC; 1989. O PTB e o trabalhismo. São Paulo: Editora Brasiliense,

BIZZARRO NETO, F.A. 2013. PMDB: organização e desenvolvimento em São Paulo (1994-2010). Dissertação de mestrado do Programa de Pós-Graduação em Ciência Política do Instituto de Filosofia e Ciências Humanas da Universidade Estadual de Campinas (IFCH-UNICAMP);

BOUCEK, F. 2009. Rethinking Factionalism: Typologies, Intra-Party Dynamics and Three Faces of Factionalism. Party Politics Vol. 15 (4) 455-485;

BRAGA, H. S. 1990. Sistemas Eleitorais do Brasil (1821-1988). Brasília, Senado Federal;

BRAGA, M. do S.S.2006. O Processo Partidário-Eleitoral Brasileiro: Padrões de Competição Política 1982-2002. São Paulo, Humanitas/Fapesp 2006; 
2008. Organizações partidárias e seleção de candidatos no estado de São Paulo. Opinião Pública, v. 14, n.2, p. 454-485;

2010. Eleições e democracia no Brasil: a caminho de partidos e sistema partidário institucionalizados. Revista Brasileira de Ciência Política, $\mathrm{n}^{\circ} 4$. Brasília, julho-dezembro de 2010, pp. 43-73;

2013. A agenda dos estudos sobre partidos políticos e sistemas partidários no Brasil. Agenda Política: Revista de Discentes de Ciência Política da UFSCAR | Vol. 1 - n. 1;

BRAGA, M. do S. S.; PIMENTEL JR, J. 2011. Os partidos políticos brasileiros realmente não importam? Opinião Pública, Campinas, v. 17, n. 2, Nov.;

BRAGA, M. do S. S., VEIGA, L. \& MIRÍADE, A. 2009. Recrutamento e Perfil dos Candidatos e dos Eleitos à Câmara dos Deputados nas Eleições de 2006. Revista Brasileira de Ciências Sociais, v. 24, p. 123-142;

BRAGA, M. do S. S., KINZO, M. D. G. (Orgs.) 2007. Eleitores e Representação Partidária no Brasil. São Paulo, Humanitas/CNPq;

BRANDÃO, G.M. 1995. O partido comunista como esquerda positiva. Lua Nova, 35; 1997. A ilegalidade mata: o partido comunista e o sistema partidário (1945-1964). Revista Brasileira de Ciências Sociais, 12(33): 23-34;

BRANDÃO, M. A. 2003. O Socialismo Democrático do Partido dos Trabalhadores. A História de uma Utopia (1979-1994). São Paulo: Annablume;

BRESSER-PEREIRA, 1984. Definição ideológica necessária para o PMDB. Jornal do $P M D B, 01.08 .1984$;

Pedroso Horta;

1987. O PMDB e as eleições de 1986. São Paulo: Fundação 1993. A Nova República: 1985-1990. São Paulo: Edições CEP;

BRITTO, L. N. de. 1988. As eleições de 1982 e as suas consequências. In: Fleischer (Org.) Da distensão à abertura: as eleições de 1982. Brasília: Editora UnB;

CALDEIRA, T. P. do Rio. 1980. Pra que serve o voto? (As eleições e o cotidiano na periferia de São Paulo). In. Lamounier (Org.) Voto de desconfiança. Eleições e mudança política no Brasil, 1970-1979. São Paulo: Vozes;

CAMURÇA, M.A. \& REIS FILHO, D.A. 2007. O Movimento Revolucionário 8 de Outubro (MR-8). Da luta armada contra a ditadura à luta eleitoral no PMDB. In: FERREIRA, J. \& REIS FILHO, D.A. (orgs.) Revolução e democracia (1964-...) Rio de Jsneiro: Ed. Civilização Brasileira;

CANTALEJO, M. H. de S. 2008. O município de Duque de Caxias e o Regime Militar: 1964-1985. Dissertação de mestrado, Universidade Federal do Rio de janeiro (UFRJ), Instituto de Filosofia e Ciências Sociais (IFCS); 
CARDOSO, F. H. LAMOUNIER, B.1978. Partidos e Deputados em São Paulo: o voto e a representação política. In: Os Partidos e as eleições no Brasil 2a. Ed. Rio de Janeiro: Paz e Terra;

Julho;

1981. PMDB: um partido de massa?. Revista do PMDB, Ano 1, n. 1,

CARDOSO, F.H. \& LAMOUNIER, B. 1978. Os Partidos e as eleições no Brasil 2a ${ }^{\mathrm{a}}$ Ed. Rio de Janeiro: Paz e Terra;

CARREIRÃO, Y de S. \& KINZO, M. D. 2004. Partidos Políticos, Preferência Partidária e Decisão Eleitoral no Brasil (1989/2002). DADOS - Revista de Ciências Sociais, Rio de Janeiro, Vol. 47, n. 1, pp. 131 a 168;

COELHO, S.A. 2003. O Partido Democrata Cristão: teores programáticos da terceira via brasileira (1945-1964). Revista Brasileira de História. São Paulo, v. 23, nº 46, pp. 201-228;

COLLIER, D. 2010. Process Tracing: Introduction and Exercises. In Barry, H. E. e Collier, D. Rethinking social inquiry: Diverse tools, shared standards Lanham: Rowan \& Littlefield Pub;

COLIN, A. 1971. Les Partis Politiques. Coleção Pensamento Político da UnB, vol. 47. Brasília: Editora UnB;

COUTO, C.G. 1997. A agenda constituinte e a difícil governabilidade. In: Lua NovaRevista de Cultura e Política, n. 39, p.33-52, São Paulo;

CYSNE, R. P. 1993. A economia brasileira no período militar. Est. Econ., São Paulo, v. 23, n. 2, p. 185-226, Maio-Agosto;

D’ARAUJO, M. C. 1996. Sindicatos, carisma e poder. O PTB de 1945-65. Rio de Janeiro: Fundação Getúlio Vargas;

2011. PSDB e PT e o Poder Executivo. Desigualdade $e$ Diversidade, Rio de Janeiro, Dossiê Especial, p. 65-100;

DELGADO, T. 2006. A história de um rebelde. Brasília: Fundação Ulysses Guimarães;

DINIZ, E. 1982. Voto e máquina política: patronagem e clientelismo no Rio de Janeiro. Rio de Janeiro: Paz e Terra;

DUARTE, C. R. 1980. A Lei Falcão: antecedentes e impacto. Voto de desconfiança. Eleições e mudança política no Brasil, 1970-1979. São Paulo: Vozes;

DUVERGER, M. 1954. Les partis politiques. $2^{\mathrm{a}}$ Ed. rev., Collin; 1959. Political parties: their organization and their activity in the modern state. New York: Wiley;

1980. Os Partidos Políticos. Rio de Janeiro: Zahar/UnB;

FERREIRA, D. P., 2001. Descentralização Partidária e Federalismo no Brasil: PFL X PMDB (1982-2000), Tese de Doutorado - DCP/USP; 
Alternativa;

FERREIRA, M. de M. 2006 A fusão do Rio de Janeiro, a ditadura militar e a transição política. In: ABREU, A. A. (Org.). A democratização no Brasil: atores e contextos. Rio de Janeiro: FGV, cap. 6, p. 163 - 203;

FLEISCHER, D. V. 1982a. Apresentação à edição brasileira. In: Sartori, G. Partidos e Sistemas Partidários. Brasília: Editora UnB;

1982b. Political Party reform in Brazil within a contexto of

Abertura. II Politico, 47(2):281-316;

Editora UnB;

1988a. Da distensão à abertura - As eleições de 1982. Brasília:

1988b. As desventuras da Engenharia política: sistema eleitoral versus sistema partidário. In: Fleischer (org.), Da distensão à abertura - As eleições de 1982. Brasília: Editora UnB;

1988c. O novo pluripartidarismo: perfil socioeconômico da Câmara dos Deputados (1979 versus 1983). In: Fleischer (org.), Da distensão à abertura - As eleições de 1982. Brasília: Editora UnB;

2002. As eleições municipais no Brasil: uma análise comparativa (1982-2000). OPINIÃO PÚBLICA, Campinas, Vol.VIII, nº1, pp.80-105;

2007. Os partidos políticos. In: Avelar \& Cintra (Org.) Sistema

político brasileiro: uma introdução. Rio de Janeiro: Fundação Konrad Adenauer, Editora Unesp;

FIGUEIREDO, A. \& LIMONGI, F. 1995. Partidos Políticos na Câmara dos Deputados: 1989 - 1994. Dados, vol. 38, no 3;

1999. Executivo e Legislativo na Nova Ordem

Constitucional. Rio de Janeiro/São Paulo, FGV/FAPESP, 1999.

2007. Instituições Políticas e Governabilidade:

Desempenho do Governo e Apoio Legislativo na Democracia Brasileira, in MELO, C. R., SAÉZ, M. A. (orgs.) A Democracia Brasileira: Balanço e Perspectivas para o Século 21. Belo Horizonte, Ed. UFMG;

FORJAZ, M. C. S. 1997. A emergência da ciência política no Brasil: aspectos institucionais. Revista Brasileira de Ciências Sociais, vol. 12, n. 35, São Paulo, fevereiro.

GASPARI, E. 2002a. A Ditadura Envergonhada, volume 1. Coleção As Ilusões Armadas, São Paulo: Companhia das Letras;

2002b. A Ditadura Escancarada, volume 2. Coleção As Ilusões

Armadas, São Paulo: Companhia das Letras;

2003. A Ditadura Derrotada, volume 3. Coleção O Sacerdote e o

Feiticeiro, São Paulo: Companhia das Letras, 2003;

2004. A Ditadura Encurralada, volume 4. Coleção O Sacerdote e o

Feiticeiro, São Paulo: Companhia das Letras;

GRINBERG, L. 2009. Partido político ou bode expiatório: um estudo sobre a Aliança Renovadora Nacional (Arena), 1965-1979. Rio de Janeiro: Mauad X; 
HAGOPIAN, F. 1996. Tradition Politics and regime change in Brazil. Cambridge: Cambridge University Press.

HEINZ, F. M. (Org.) 2005. O Parlamento em tempos interessantes: breve perfil da Assembléia Legislativa e de seus deputados - 1947-1982 (Os 170 anos do Parlamento Gaúcho: v. 3). Porto Alegre: CORAG;

HIPPOLITO, L. 2012. De Raposas e Reformistas: o PSD e a experiência democrática brasileira (1945-64). Rio de Janeiro: Ed. Paz e Terra, $2^{\mathrm{a}} \mathrm{Ed}$;

HUNTINGTON, S. 1968. Political order in changing societies. New Haven: Yale University Press;

JAGUARIBE, H. 1962. As eleições de 62. Revista Tempo Brasileiro, Rio de Janeiro, n.2, Dezembro;

KATZ, R. S. \& Mair, P. 1995. Changing models of party organization and party democracy - The emergence of the Cartel party. Party Politics, vol. 1, n. 1, pp 5-28;

KECK, M. 1991. A Lógica da Diferença: O Partido dos Trabalhadores na Construção da Democracia no Brasil. São Paulo: Ática;

KEY, V.O. 1949. Southern politics. New York: Knopf;

KINZO, M. D. G. 1980. Novos partidos: o início do debate. In: B. LAMOUNIER (org.), Voto de desconfiança: eleições e mudança política no Brasil, 1970-1979. Petrópolis: Vozes;

1988. Oposição e autoritarismo: gênese e trajetória do MBD, 1966 - 1979. São Paulo: Vértice;

1989. Quadro partidário brasileiro na Nova República. Documento de trabajo - Clacso, Buenos Aires; 1990. O quadro partidário e a Constituinte. In: B. LAMOUNIER (org.), De Geisel a Collor: o balanço da transição. São Paulo: IDESP/Editora Sumaré; 1993. Radiografia do quadro partidário brasileiro. São Paulo: Konrad Adenauer Stiftung; 1996. PMDB: Partido do Movimento Democrático Brasileiro. St. Augustin (Alemanha): Konrad Adenauer Stiftung; 2001. A democratização brasileira: um balanço do processo político desde a transição. São Paulo Perspec., São Paulo, 15(4), Dec.; 2004. Partidos, eleições e democracia no Brasil pós-1985. RBCS Revista Brasileira de Ciências Sociais, v.19, n.54, p.24-41;

KIRCHHEIMER, O. 1966. The transformation of the Western European party systems. In: LaPalombara, J. e Weiner, M., Political parties and political development. Princeton: Princeton University Press, p. 177-200;

KOLODNY, R. 1999. Moderate party factions in the US House of Representatives, In: John C Green and Daniel M. Shea (Orgs.) The State of the parties: The changing role of contemporary American Parties, $3^{\mathrm{a}}$ Ed., Lanham, MD, Boulder, CO, New York and Oxford: ROwman and Littlefield; 
KOTSCHO, R. 1984. Explode um novo Brasil: Diário da campanha das Diretas. São Paulo:Brasiliense;

LAMOUNIER, B.1978a. Comportamento eleitoral em São Paulo: passado e presente. In: Os Partidos e as eleições no Brasil 2a . Ed. Rio de Janeiro: Paz e Terra;

1978b. Presidente Prudente: o crescimento da oposição num reduto arenista. In: (Reis Org.) Os partidos e o regime - A lógica do processo eleitoral brasileiro. São Paulo: Símbolo;

1980. Voto de desconfiança. Eleições e mudança política no Brasil, 1970-1979. São Paulo: Vozes;

1989. Partidos e Utopias: o Brasil no limiar dos anos 90. São Paulo:

Edições Loyola;

(Org.) 1990. De Geisel a Collor: o balanço da transição. São Paulo: IDESP, Editora Sumaré;

LAMOUNIER, B. \& KINZO, M. D. G. 1978. Partidos políticos, representação e processo eleitoral no Brasil, 1945-1978. Revista Brasileira de Informação Bibliográfica em Ciências Sociais-BIB, Rio de Janeiro, n. 05;

LAMOUNIER, B. \& MENEGUELlO, R. 1986. Partidos Políticos e Consolidação Democrática. São Paulo: Brasiliense;

LAVARERA, A. 1991. A Democracia nas urnas - O processo partidário eleitoral brasileiro. Rio de Janeiro: IUPERJ/Rio Fundo Editora;

LEONELLI, D. \& OLIVEIRA, D. 2004. Diretas Já: 15 meses que abalaram a ditadura. Rio de Janeiro: Record;

LIMA JR, O. B. de.1978. Articulação de interesses, posição socioeconômica e ideologia: as eleições de 1976 em Niterói. In Reis (Org.) Os partidos e o regime - A lógica do processo eleitoral brasileiro. São Paulo: Símbolo;

1983. Partidos Políticos Brasileiros 45 a 64. Rio de Janeiro:

Graal;

São Paulo: Loyola;

1993. Democracia e Instituições Políticas no Brasil dos Anos 80.

1999. Partidos, eleições e Poder Legislativo. In: MICELI, Sérgio

(org.). O que ler na Ciência Social brasileira: Política. São Paulo: Sumaré. p. 13-57;

LIMA Jr, SCHMITT, R.A. \& NICOLAU, J.C.M. 1992. A produção brasileira recente sobre partidos, eleições e comportamento político: balanço bibliográfico. $B I B$, Rio de Janeiro, n. 34, $2^{\circ}$ semestre, pp.3-66;

LIMONGI, F. \& CORTEZ, R. 2010. As eleições de 2010 e o quadro partidário. Novos Estudos CEBRAP, n. 88, PP. 21-37;

LIÑAN, A. P. \& MAINWARING, S. P. 1998. Disciplina partidária: o caso da Constituinte. Lua Nova, n.44, p.107-136; 
LIPPI, M. L. L., 1972. O Partido Social democrático, Dissertação de Mestrado IUPERJ;

LOYOLA, M. A. 1980. Os sindicatos e o PTB. Petrópolis: Vozes;

MAINWARING, S. 2002. Sistemas Partidários em Novas Democracias: O Caso do Brasil. Rio de Janeiro: FGV;

MARINGONI, G. 2012. Os 30 anos do "Esperança e mudança". Revista Carta Maior, disponível em:

www.cartamaior.com.br/templates/colunaImprimir.cfm?coluna_id=5403;

MARQUES, J. R. \& FLEISCHER, D. V. 1999. De facção a partido: o Partido da Social Democracia Brasileira (PSDB) (1987/1995). Brasília: Instituto Teotônio Vilela;

MARTINS Jr, J.P. 2001. A trajetória do PTB e o jogo de alianças eleitorais 1945-1964. Dissertação de mestrado, DCP - FFLCH - Universidade de São Paulo;

MDB. 1978. Constituinte com Anistia: compromissos políticos, sociais e econômicos. Coleção Alberto Pasqualini, Brasília;

MELHEM, C. S. 1998. Política de botinas amarelas - o MDB-PMDB paulista de 1965 a 1988. São Paulo: Hucitec;

MELHEM, C. S. \& RUSSO, S. M. 1987. PMDB, democracia sempre. São Paulo: Global Editora;

São Paulo: Artemeios;

2004. Dr. Ulysses - o homem que pensou o Brasil.

MELO, C. R. 2000. Partidos e Migração Partidária na Câmara dos Deputados. Dados vol.43 n.2 Rio de Janeiro;

2004. Retirando as cadeiras do lugar: migração partidária na Câmara dos Deputados (1985-202). Belo Horizonte: Editora UFMG;

2006. Sistema partidário, presidencialismo e reforma política no Brasil. In: SOARES, G. e RENNÓ, L. (orgs.) Reforma política: lições da história recente. Rio de Janeiro: Fundação Getúlio Vargas;

MELO, C. R. \& CAMARA, R. 2012. Estrutura da competição pela Presidência e consolidação do sistema partidário no Brasil. Dados (online), vol. 55, n. 1, PP. 71-117;

MENEGOZZO, C.H.M. 2013. Partido dos Trabalhadores - Bibliografia comentada (1978-2002). São Paulo: Fundação Perseu Abramo;

MENEGUELLO, R. 1989. PT - A formação de um partido, 1979-1982. Rio de Janeiro: Paz e Terra; doutorado, IFCH-Unicamp;

R. 1996. Partidos e governos no Brasil contemporâneo. Tese de

MEZAROBBA, G. 2006. Um acerto de contas com o futuro: a anistia e suas consequências. São Paulo: Humanitas/Fapesp; 
MICHELS, R, 1915. Political Parties - A sociological study of the oligarchical tendencies of modern democracies. New York: Hearst's International Library Co.;

MIYAMOTO, S. 1980. Eleições de 1978 em São Paulo: a campanha. In: LAMOUNIER, B. (org.), Voto de desconfiança: eleições e mudança política no Brasil, 1970-1979. Petrópolis: Vozes;

NADER, A.B. 1998. Autênticos do MDB, semeadores da democracia - história oral de vida política. São Paulo: Paz e Terra;

NICOLAU, J.1996. Multipartidarismo e democracia: um estudo sobre o sistema partidário brasileiro, 1985-1994. Rio de Janeiro: Editora FGV;

1998. Dados eleitorais no Brasil (1982-1996). Rio de Janeiro: Editora Revan e IUPERJ/UCAM;

2004. Partidos na República de 1946: Velhas teses, novos Dados. In: DADOS, Vol 47, No. 1. Págs. 85-128;

2010. Partidos e Sistemas Partidários: 1985-2009. In: LESSA, Renato (org.). Horizontes das Ciências Sociais no Brasil: Ciência Política. São Paulo: Barcarolla, p. 217-240;

NOVAES, C. A. M. 1994. Dinâmica Institucional da Representação: Individualismo e Partidos na Câmara dos Deputados. Novos Estudos Cebrap, nº 38;

OLIVEIRA, F.de. 1992. Collor: a falsificação da ira. Rio de Janeiro: Imago;

OLIVEIRA, B.K.V. 2012. Da transição democrática ao governo Lula: a trajetória e o papel político do PMDB. Dissertação de mestrado, DCS - UFCE;

PANEBIANCO, A. 2005. Modelos de Partidos. Organização e poder nos partidos políticos. São Paulo: Martins Fontes;

PASQUARELLI, B. \& BIZZARRO NETO, F. A. 2012. O PMDB no centro do sistema político brasileiro (1986-2010). $8^{\circ}$ Encontro da ABCP 01 a 04/08/2012, Gramado, RS AT03 - Eleições e Representação Política;

PEREIRA, C. \& MUELLER, B. 2000. Uma teoria da preponderância do Poder Executivo: o sistema de comissões no Poder Legislativo. RBCS- Revista Brasileira de Ciências Sociais, v.15, n.43, p.45-67;

PERISSINOTO, R. 2013. Comparação, história e interpretação. Por uma ciência política histórico-interpretativa. RBCS, Vol. 28, n 83, outubro;

PERES, P. S. 2002. Sistema partidário e instabilidade eleitoral no Brasil. In: PINTO, C. \& SANTOS, A.M. dos. Partidos no Cone Sul. Rio de Janeiro: Fundação Konrad Adenauer;

POWER, T. 1997. The political right in postauthoritarian Brazil. Elites, Institutions and democratization. University Park: Pennsylvania University Press; 
POWER, T. \& ZUCCO, C. (Orgs.). 2011. O Congresso Por Ele Mesmo: Autopercepções da Classe Política Brasileira. Belo Horizonte: UFMG;

REIS, F.W. 1978a. As eleições em Minas Gerais. . In: Os Partidos e as eleições no

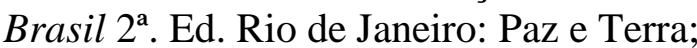

1978b Os partidos e o regime - A lógica do processo eleitoral brasileiro.

São Paulo: Símbolo;

2010. Identidade política, desigualdade e partidos brasileiros. Novos Estudos, n. 87, Julho;

RIBEIRO, P. F. 2010. Dos sindicatos ao governo. A organização nacional do PT de 1980 a 2005. São Carlos: EdUFSCAR;

RIBEIRO, R. L. M. 2011. A Decadência Longe do Poder - Refundação e Crise do PFL. Dissertação de mestrado, DCP - FFLCH - Universidade de São Paulo;

ROCHA, C. 2011. O uso de métodos qualitativos em estudos de cultura política e comportamento eleitoral. Texto para circulação interna - Grupo de Estudos Política brasileira - Departamento de Ciência Política USP;

RODRIGUES, L. M. 2002. Partidos, Ideologia e Composição Social. São Paulo: Edusp, 2002;

ROMA, C. 1997. A social democracia no Brasil: organização, participação no governo e desempenho eleitoral do PSDB, 1988-1998 . Dissertação de mestrado, DCP - FFLCH - Universidade de São Paulo; 2002. A Institucionalização do PSDB entre 1988 e 1999. Revista Brasileira de Ciências Sociais, v.17, n. 49;

2006. Organizaciones de Partido en Brasil: El PT y el PSDB bajo Perspectiva Comparada. América Latina Hoy, Salamanca, n. 44, p. 153-184;

ROSE, R. 1976. The problem of party government. Harmondsworth: Penguin Books, p. 312-328;

SÁ, J. M. de. 2011. A organização institucional do Partido do Movimento Democrático Brasileiro (PMDB) e sua atuação na arena eleitoral do estado do Piauí: 1986-2006. Dissertação de mestrado, Programa de Pós-Graduação em Ciência Política do Centro de Ciências Humanas e Letras da Universidade Federal do Piauí, UFPI;

SADEK, M. T. 1989a. A interiorização do PMDB nas eleições de 1986 em São Paulo. In: Eleições 1986. São Paulo: IDESP/Vertice;

1989b. Eleições 1988: retórica ou rumo pluripartidário. In: Lua Nova-

Revista de Cultura e Política, n.17, p.111-132, São Paulo; 1993. Sistema Partidário Brasileiro: a debilidade institucional. Instituto de Estudios Económicos, Sociais e Politicos, São Paulo; Working Paper n.72 Barcelona;

SALES, J. R. 2007. Entre o fechamento e a abertura: a trajetória do PCdoB da guerrilha do Araguaia à nova República (1974-1985). História, São Paulo, v.26, n.2,p. 340-365. 
SAMPAIO, R. 1982. Adhemar de Barros e o PSP. São Paulo: Global Editora;

SARMENTO, C. E. 2002. O espelho partido da metrópole: Chagas Freitas e o campo político carioca (1950-83): liderança, voto e estruturas clientelistas. Tese (Doutorado) IfcsfUFRJ, Rio de Janeiro;

SANTOS, A. M. dos, 2001. Sedimentação de lealdades partidárias no Brasil: tendências e descompassos. RBCS- Revista Brasileira de Ciências Sociais, Vol. 16 no 45 fevereiro;

SANTOS, A. C. 2011. A transição do regime militar para a democracia: o Partido Comunista do Brasil (PCdoB) entre enlaces e jogos da política, Anais do XXVI Simpósio Nacional de História - ANPUH, São Paulo, julho;

SARTORI, G. 1982. Partidos e sistemas partidários. Brasília: Editora Unb;

SCHWARTZMAN, S. 1971. Veinte años de democracia representativa en Brasil, 1945-1964. Revista Latino Americana de Ciência Política, v.2, n.1, Abril;

SCHMITT, R. 2000. Partidos Políticos no Brasil (1945-2000). Rio de Janeiro: Jorge Zahar Editora;

SECCO, L. 2011. História do PT. São Paulo: Editora Ateliê;

SEGRILLO, A. 2005. Rússia e Brasil em transformação: uma breve história dos partidos russos e brasileiros na democratização política. Rio de Janeiro: 7Letras;

SIMONI Jr., S. \& BORGES, T.D.P. 2011. O PMDB e sua evolução frente à bipolarização da competição partidária brasileira. II Fórum Brasileiro de Pós-Graduação em Ciência Política, São Carlos, SP;

SKIDMORE, T. E. 2004. Brasil: De Castelo a Tancredo, 1964-1985. São Paulo: Paz e Terra, $8^{\mathrm{a}}$ ed;

SOARES, G. A. 1973. Sociedade e Política no Brasil. São Paulo: Difel;

Petrópolis: Vozes. 1984. Colégio eleitoral, convenções partidárias e eleições diretas.

SOUSA, P. de. 1964. Eleições de 1962: decomposição partidária e caminhos da reforma. Revista Brasileira de Estudos Políticos, Belo Horizonte, n.16, PP 7-19, Janeiro;

SOUZA, M. C. C. 1990. Estados e Partidos Políticos no Brasil (1930 a 1964) $3^{a}$ Edição, São Paulo: Editora Alfa-Ômega;

TAAGEPERA, R. \& SHUGART, M. S. 1989. Seats and votes: the effects and determinants of electoral systems. New Haven, CT and London: Yale University Press;

TRINDADE, H. 1985. Partidos políticos e transição democrática: populismo/antipopulismo na política brasileira. Reunião GT - Elites políticas da Associação Nacional 
de Pós-Graduação e Pesquisa em Ciências Sociais - Águas de São Pedro - São Paulo outubro;

TRINDADE, R.T.Z. 2011. A divisão das oposições e as oposições divididas: a rivalidade PDT X PMDB na campanha eleitoral de 1982 no Rio Grande do Sul. Monografia do Departamento de História do Instituto de Filosofia e Ciências Humanas da UFRGS;

TURNER, J. 2000. The Tories and Europe. Manchester: Manchester University Press;

VEIGA, L. F. 2007 Mudanças e Continuidades na Identificação Partidária e na Avaliação das Principais Legendas após 2002. Opiniao Pública, v.13, n.2, p.340-365;

VIANNA, L. W. 1978. O Sistema partidário e o Partido Democrata Cristão. Cadernos CEDEC, São Paulo: Brasiliense;

VISCARDI, C. M. R. 2012. O teatro das oligarquias. Belo Horizonte: Fino Franco Editora;

WEFFORT, F. 1978. O populismo na política brasileira. Rio de Janeiro : Paz e Terra;

WEBER, M. 1999. A "objetividade" do Conhecimento nas Ciências Sociais $7^{\text {a }}$ Edição. São Paulo: Editora Ática.

\section{Outras fontes:}

Acervo Coluna Castello Branco - Jornal do Brasil

http://www.carloscastellobranco.com.br/index.php

Acervo CPDOC/FGV

http://www.fgv.br/cpdoc/busca/Busca/BuscaConsultar.aspx

Acervo Folha de S. Paulo

http://acervo.folha.com.br/fsp

Acervo O Estado de S. Paulo

http://acervo.estadao.com.br/

Acervo Revista Veja

http://veja.abril.com.br/acervodigital/

Site oficial do PMDB

http://pmdb.org.br/ 
Revistas do PMDB Ano I, N. 1 (Julho de 1981), N. 2 (Novembro de 1981) e N. 3 (Agosto/Setembro de 1982), e Ano II, N. 4 (Outubro/Novembro de 1982) Fundação Pedroso Horta. 